\title{
Diastereodivergent Access to Syn and Anti 3,4-Substituted $\beta$-Fluoropyrrolidines: Enhancing or Reversing Substrate Preference
}

\author{
Kasper Fjelbye, ${ }^{\mathrm{a}, \mathrm{b}}$ Mauro Marigo, ${ }^{\mathrm{a}}$ Rasmus Prætorius Clausen, ${ }^{\mathrm{b}}$ Karsten Juhl ${ }^{\mathrm{a}, *}$ \\ ${ }^{a}$ Discovery Chemistry and DMPK, H. Lundbeck A/S, Ottiliavej 9, 2500 Valby, Danmark \\ ${ }^{\mathrm{b}}$ Department of Drug Design and Pharmacology, Faculty of Health and Medical Sciences, University of \\ Copenhagen, Universitetsparken 2, DK-2100 Copenhagen, Denmark
}

\section{Supporting Information}

\section{Contents}

General Methods.

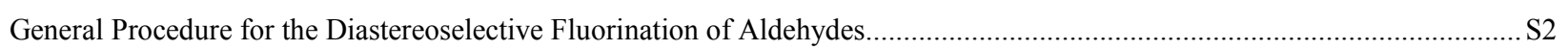

General Procedure for the Reduction of Purified Aldehydes to the Corresponding Alcohols .............................................. S2

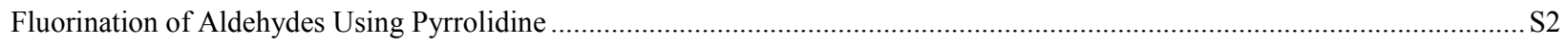

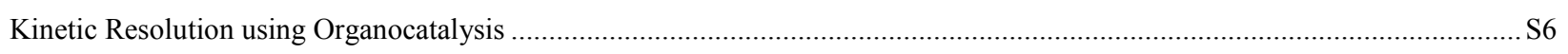

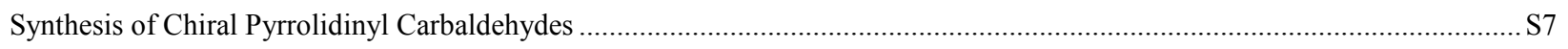

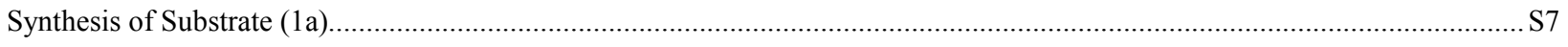

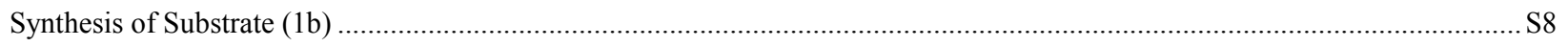

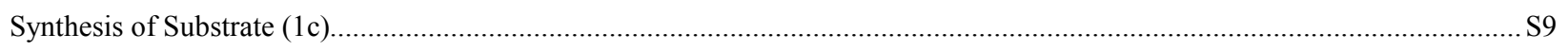

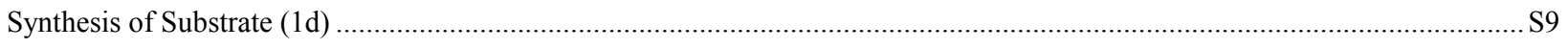

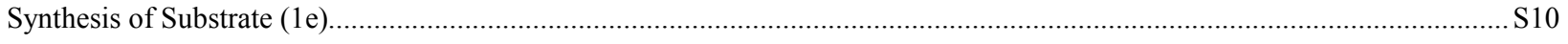

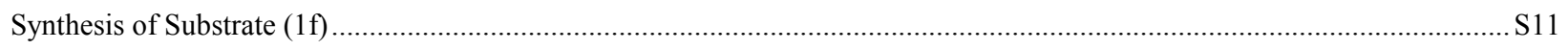

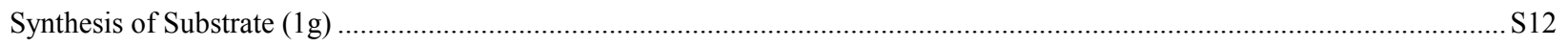

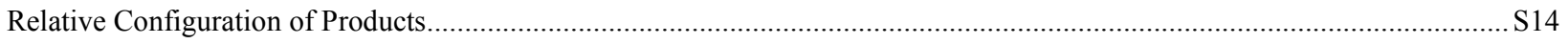

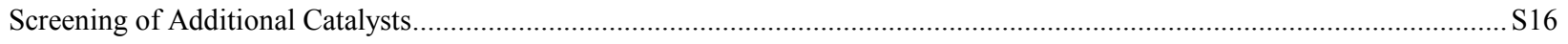

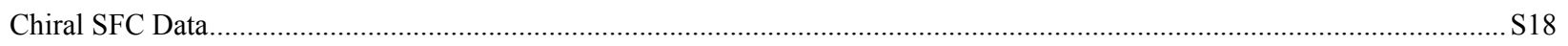

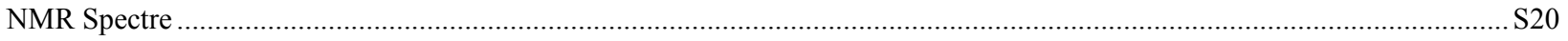




\section{General Methods}

LCMS data were acquired using a Waters Acquity UPLC-MS consisting of a Waters Acquity system including column manager, binary solvent manager, sample organizer, PDA detector (operating at $254 \mathrm{~nm}$ ), ELS detector, and TQ-MS equipped with APPIsource operating in positive ion mode. LC-conditions: The column was Acquity UPLC BEH C18 $1.7 \mu \mathrm{m} ; 2.1 \times 50 \mathrm{~mm}$ operating at $60{ }^{\circ} \mathrm{C}$ with $1.2 \mathrm{~mL} / \mathrm{min}$ binary gradient consisting of $\mathrm{H}_{2} \mathrm{O}+0.05 \%$ trifluoroacetic acid (TFA) (A) and $\mathrm{MeCN}+5 \% \mathrm{H} \mathrm{O}_{2} \mathrm{O}+0.05 \%$ TFA (B). Gradient: 0.00 min: $10 \%$ B; 1.00 min: $100 \%$ B; $1.01 \mathrm{~min}: 10 \%$ B; $1.15 \mathrm{~min}: 10 \% \mathrm{~B}$. The retention times provided in the experimental section shall be compared to the total run time of $1.15 \mathrm{~min}$. The LCMS data provided for determination of crude diastereomeric ratios are acquired on an Acquity UPLC BEH C18 $1.7 \mu \mathrm{m} ; 2.1 \times 150 \mathrm{~mm}$ column with a total run time of $3.60 \mathrm{~min}$, and the extracted-ion chromatograms (XIC) were used for analysis of the crude diastereomeric ratios. HRMS data were acquired with a Bruker Daltonic MicroTOF with internal calibration using ESI in the positive mode. NMR data were collected with a Bruker 600-Avance-III spectrometer equipped with a $5 \mathrm{~mm}$ TCI cryoprobe operating at 600 and $151 \mathrm{MHz}$ for ${ }^{1} \mathrm{H}$ and ${ }^{13} \mathrm{C}$, respectively. ${ }^{19} \mathrm{~F}$ NMR spectra were recorded with a Bruker 500-Avance spectrometer equipped with a $5 \mathrm{~mm}$ QNP probe operating at $470.6 \mathrm{~Hz}$, using $\mathrm{CFCl}_{3}$ as reference. The solvents used for NMR were $\mathrm{CDCl}_{3}$, with reference signals for $\mathrm{CHCl}_{3}(\delta=$ $\left.7.26 \mathrm{ppm},{ }^{1} \mathrm{H}\right)$ and $\left(\delta=77.16 \mathrm{ppm},{ }^{13} \mathrm{C}\right)$, and DMSO- $d 6$ with the reference signals for residual DMSO $\left(\delta=2.50 \mathrm{ppm},{ }^{1} \mathrm{H}\right)$ and $(\delta$ $=39.51 \mathrm{ppm},{ }^{13} \mathrm{C}$ ) using TMS as internal reference. The chemical shifts are provided in ppm and broad proton signals are labeled (br). $N$-Fluorobenzenesulfonimide (NFSI), $(S)$-2-(bis(3,5-bis(trifluoromethyl)phenyl)((trimethylsilyl)oxy)methyl)pyrrolidine $(S)$ 7, $\quad(R)$-2-(bis(3,5-bis(trifluoromethyl)phenyl)((trimethylsilyl)oxy)methyl)pyrrolidine $\quad(R)$-7, $\quad(S)$-5-benzyl-2,2,3trimethylimidazolidin-4-one 2,2-dichloroacetate $(S)$-8, $(R)$-5-benzyl-2,2,3-trimethylimidazolidin-4-one 2,2-dichloroacetate $(R)$-8 and $\mathrm{NaBH}_{4}$ were purchased from Sigma-Aldrich. Due to hydrate formation during analysis, some of the fluorinated aldehydes were additionally characterized after reduction to the corresponding alcohols using a general procedure described below.

\section{General Procedure for the Diastereoselective Fluorination of Aldehydes}

To a solution of 1a-g in a specified solvent $(0.5 \mathrm{M})$ was added catalyst $(10-20 \mathrm{~mol} \%)$ and the mixture was stirred for $5 \mathrm{~min}$ at $\mathrm{rt}$ after which $\mathrm{N}$-fluorobenzenesulfonimide (NFSI) (1.2 equiv) was added and the resulting mixture was stirred at $40{ }^{\circ} \mathrm{C}$ for $14-20 \mathrm{~h}$. Unless otherwise noted, the reaction mixture was diluted with MTBE and loaded directly through a filter onto $\mathrm{SiO}_{2}$ for flash chromatographic purification to yield 2a-g or 3a-g, respectively.

\section{General Procedure for the Reduction of Purified Aldehydes to the Corresponding Alcohols}

To a solution of the purified aldehyde in $\mathrm{MeOH}(0.02-0.1 \mathrm{M})$ was added $\mathrm{NaBH}_{4}$ (3 equiv) and the reaction mixture was stirred for $30 \mathrm{~min}$. Subsequently, excess hydride donor was quenched by the addition of $\mathrm{H}_{2} \mathrm{O}$ followed by EtOAc and the phases separated. The aqueous phase was then extracted with EtOAc and the combined organic phases were washed with brine, dried over $\mathrm{MgSO}_{4}$, filtered and concentrated in vacuo to provide the corresponding alcohol.

\section{Fluorination of Aldehydes Using Pyrrolidine}

To a solution of each of the respective aldehydes $(0.1 \mathrm{mmol})$ in MTBE $(0.5 \mathrm{M})$ was added pyrrolidine $(0.020 \mathrm{mmol}, 20 \mathrm{~mol} \%)$ and the mixture was stirred for $5 \mathrm{~min}$ at $\mathrm{rt}$ after which $N$-fluorobenzenesulfonimide $(0.12 \mathrm{mmol}, 1.2$ equiv $)$ was added and the resulting mixture was stirred at $40{ }^{\circ} \mathrm{C}$ for $14-20 \mathrm{~h}$. Subsequently, the reaction mixture was diluted with MTBE and loaded directly through a filter on $\mathrm{SiO}_{2}$ for flash chromatographic purification to yield the fluorinated product.

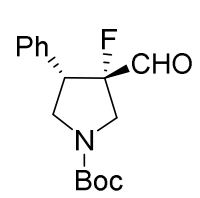

tert-Butyl (3S,4S)-3-fluoro-3-formyl-4-phenylpyrrolidine-1-carboxylate (2a) In accordance with the general procedure, 1a (28 mg, $0.10 \mathrm{mmol})$ was reacted with $(R)-7(6 \mathrm{mg}, 0.01 \mathrm{mmol}, 10 \mathrm{~mol} \%)$ and NFSI (39 $\mathrm{mg}, 0.12$ mmol, 97\%) in MTBE for $14 \mathrm{~h}$ to provide $2 \mathrm{a}(29 \mathrm{mg}, 0.10 \mathrm{mmol}, 100 \%$ yield, $98: 2 \mathrm{dr}$ ) as a colorless oil. The crude dr was determined by LCMS (XIC) after reduction to the alcohol 11a using $\mathrm{NaBH}_{4}$ in $\mathrm{MeOH}$ on an analytical scale $\left(t_{\mathrm{R}}\right.$ major $=2.54 \mathrm{~min} ; t_{\mathrm{R}}$ minor $\left.=2.50 \mathrm{~min}, 96: 4 \mathrm{dr}\right) .{ }^{1} \mathrm{H} \mathrm{NMR}\left(600 \mathrm{MHz}, \mathrm{CDCl}_{3}\right) \delta 9.70-9.65$

$(\mathrm{m}, 1 \mathrm{H}), 7.36-7.31(\mathrm{~m}, 3 \mathrm{H}), 7.29-7.26(\mathrm{~m}, 2 \mathrm{H}), 4.05-3.66(\mathrm{~m}, 5 \mathrm{H}), 1.48(\mathrm{~s}, 9 \mathrm{H}) ;{ }^{13} \mathrm{C} \mathrm{NMR}\left(151 \mathrm{MHz}, \mathrm{CDCl}_{3}\right) \delta 199.4(\mathrm{~d}, J$ $=43.7 \mathrm{~Hz}), 154.0(\mathrm{~d}, J=24.5 \mathrm{~Hz}), 132.4,129.7,129.2,129.1,128.7,128.7,128.5,128.4,127.9,80.4,54.6(\mathrm{~d}, J=24.1 \mathrm{~Hz}), 54.4$ $(\mathrm{d}, J=24.0 \mathrm{~Hz}), 51.7(\mathrm{~d}, J=19.4 \mathrm{~Hz}), 51.1(\mathrm{~d}, J=19.6 \mathrm{~Hz}), 49.9,49.3,28.4 .[\alpha]_{\mathrm{D}}{ }^{22}=-35.1^{\circ}\left(c=0.45, \mathrm{CHCl}_{3}\right)$.

The product 2a was additionally characterized after reduction in accordance with the general procedure to provide 11a. ${ }^{1} \mathrm{H}$ NMR $\left(600 \mathrm{MHz}, \mathrm{CDCl}_{3}\right) \delta 7.36-7.28(\mathrm{~m}, 5 \mathrm{H}), 3.99-3.69(\mathrm{~m}, 5 \mathrm{H}), 3.64-3.57(\mathrm{~m}, 1 \mathrm{H}), 3.43-3.27(\mathrm{~m}, 1 \mathrm{H}), 1.50-1.47(\mathrm{~m}, 9 \mathrm{H})$. 
${ }^{13} \mathrm{C} \mathrm{NMR}\left(151 \mathrm{MHz}, \mathrm{CDCl}_{3}\right) \delta 154.3,134.1,134.1,129.4,128.5,127.8,79.9,63.70-62.88(\mathrm{~m}), 54.68-53.82(\mathrm{~m}), 50.5,49.8$, $49.28-48.52(\mathrm{~m}) .28 .5$ (conformers, the carbon bound to fluorine was not detected). ${ }^{19} \mathrm{~F} \mathrm{NMR}\left(471 \mathrm{MHz}, \mathrm{CDCl}_{3}\right) \delta-63.23,-$ 63.31, -176.93, -177.30 (conformers). HRMS-ESI: $m / z$ for $\mathrm{C}_{16} \mathrm{H}_{22} \mathrm{FNO}_{3} \mathrm{Na}\left[\mathrm{MNa}^{+}\right]$calcd. 318.1476; found 318.1476.

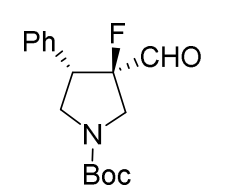

tert-Butyl (3R,4S)-3-fluoro-3-formyl-4-phenylpyrrolidine-1-carboxylate (3a) In accordance with the general procedure, 1a (28 mg, $0.10 \mathrm{mmol})$ was reacted with $(S)-8(7 \mathrm{mg}, 0.020 \mathrm{mmol}, 20 \mathrm{~mol} \%)$ and NFSI $(38 \mathrm{mg}$, $0.12 \mathrm{mmol})$ in $10 \% \mathrm{i}$-PrOH in THF for $16 \mathrm{~h}$ to provide 3a $(18.7 \mathrm{mg}, 0.064 \mathrm{mmol}, 64 \%$ yield, $98: 2 \mathrm{dr})$ as a colorless oil. The crude dr was determined by LCMS (XIC) after reduction to the alcohol using $\mathrm{NaBH}_{4}$ in $\mathrm{MeOH}$ on an analytical scale $\left(t_{\mathrm{R}}\right.$ major $=2.47 \mathrm{~min} ; t_{\mathrm{R}}$ minor $\left.=2.52 \mathrm{~min}, 93: 7 \mathrm{dr}\right){ }^{1} \mathrm{H} \mathrm{NMR}\left(600 \mathrm{MHz}, \mathrm{CDCl}_{3}\right) \delta$ $9.41(\mathrm{~d}, J=4.2 \mathrm{~Hz}, 1 \mathrm{H}), 7.36-7.27(\mathrm{~m}, 3 \mathrm{H}), 7.18-7.15(\mathrm{~m}, 2 \mathrm{H}), 4.07-3.63(\mathrm{~m}, 5 \mathrm{H}), 1.51(\mathrm{~s}, 9 \mathrm{H}) ;{ }^{13} \mathrm{C} \mathrm{NMR}(151 \mathrm{MHz}$, $\left.\mathrm{CDCl}_{3}\right) \delta 197.3-196.6(\mathrm{~m}), 154.2-154.0(\mathrm{~m}), 134.4,129.2,128.3,127.8,80.5,53.4,52.4-51.2(\mathrm{~m}), 51.3-49.5(\mathrm{~m}), 28.4 .{ }^{19} \mathrm{~F}$ NMR (471 MHz, $\mathrm{CDCl}_{3}$ ) $\delta-159.49,-160.68$ (two conformers), -167.56. HRMS-ESI: $m / z$ for $\mathrm{C}_{12} \mathrm{H}_{13} \mathrm{FNO}_{3}\left[\mathrm{MH}-t \mathrm{Bu}^{+}\right.$calcd. 238.0874; found 238.0874. $[\alpha]_{\mathrm{D}}^{22}=-24.8^{\circ}\left(c=0.25, \mathrm{CHCl}_{3}\right)$.

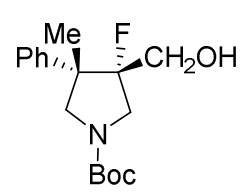

tert-Butyl (3S,4S)-3-fluoro-3-(hydroxymethyl)-4-methyl-4-phenylpyrrolidine-1-carboxylate (11b) In accordance with the general procedure, $\mathbf{1 b}(73 \mathrm{mg}, 0.25 \mathrm{mmol})$ was reacted with $(R)-7$ (15 mg, $0.025 \mathrm{mmol}$, $10 \mathrm{~mol} \%$ ) and NFSI $(95 \mathrm{mg}, 0.3 \mathrm{mmol})$ in MTBE for $14 \mathrm{~h}$ to provide $\mathbf{2 b}$ as a yellow oil. The semi-pure $\mathbf{2 b}$ was diluted in $\mathrm{MeOH}(3 \mathrm{~mL})$ after which $\mathrm{NaBH}_{4}(29 \mathrm{mg}, 0.76 \mathrm{mmol}, 3$ equiv) was added and the mixture was stirred for $30 \mathrm{~min}$. EtOAc $(5 \mathrm{~mL})$ was added followed by $\mathrm{H}_{2} \mathrm{O}(2 \mathrm{~mL})$ and the phases were separated. The aqueous phase was extracted with EtOAc $(2 \times 5 \mathrm{~mL})$, the organic phases combined, dried over $\mathrm{MgSO}_{4}$, filtered and concentrated in vacuo to provide a yellow oil that was purified using silica gel chromatography to provide $11 \mathbf{b}(58 \mathrm{mg}, 0.187$ mmol, 74\% yield, 98:2 dr) as a colorless oil. The crude dr was determined by LCMS (XIC) of the crude reaction mixture after reduction $\left(t_{\mathrm{R}}\right.$ major $=2.56 \mathrm{~min} ; t_{\mathrm{R}}$ minor $\left.=2.64 \mathrm{~min}, 96: 4 \mathrm{dr}\right) .{ }^{1} \mathrm{H} \mathrm{NMR}\left(600 \mathrm{MHz}, \mathrm{CDCl}_{3}\right) \delta 7.46-7.41(\mathrm{~m}, 2 \mathrm{H}), 7.37-7.33(\mathrm{~m}$, 2H), $7.30-7.27(\mathrm{~m}, 1 \mathrm{H}), 4.18-4.11(\mathrm{~m}, 1 \mathrm{H}), 3.91-3.72(\mathrm{~m}, 4 \mathrm{H}), 3.62-3.49(\mathrm{~m}, 1 \mathrm{H}), 2.06-1.97(\mathrm{~m}, 1 \mathrm{H}), 1.50-1.47(\mathrm{~m}$, 9H), $1.46-1.44(\mathrm{~m}, 3 \mathrm{H}) ;{ }^{13} \mathrm{C}$ NMR $\left(151 \mathrm{MHz}, \mathrm{CDCl}_{3}\right) \delta 155.0(\mathrm{~d}, J=22.8 \mathrm{~Hz}), 138.8(\mathrm{~d}, J=4.4 \mathrm{~Hz}), 128.4,128.3,128.1$, 128.0, 127.4, 105.9 - $103.9(\mathrm{~m}), 80.2,63.0-62.6(\mathrm{~m}), 57.5,56.6,54.3-53.7(\mathrm{~m})$ 28.7, 23.0, 23.0. ${ }^{19} \mathrm{~F} \mathrm{NMR}\left(471 \mathrm{MHz}, \mathrm{CDCl}_{3}\right)$ $\delta$-162.08, -162.25 (conformers). HRMS-ESI: $m / z$ for $\mathrm{C}_{13} \mathrm{H}_{17} \mathrm{FNO}_{3}\left[\mathrm{MH}^{+}-t \mathrm{Bu}\right]$ calcd. 254.1187; found 254.1183. [ $\left.\alpha\right]_{\mathrm{D}}{ }^{22}=-186^{\circ}$ $\left(c=0.022, \mathrm{CHCl}_{3}\right)$.

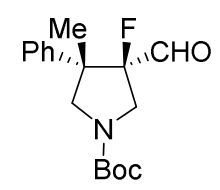

tert-Butyl $(3 R, 4 S)$-3-fluoro-3-formyl-4-methyl-4-phenylpyrrolidine-1-carboxylate (3b) In accordance with the general procedure, $\mathbf{1 b}(72 \mathrm{mg}, 0.25 \mathrm{mmol})$ was reacted with $(S)-8(17 \mathrm{mg}, 0.05 \mathrm{mmol}, 20 \mathrm{~mol} \%)$ and NFSI (94 mg, $0.3 \mathrm{mmol})$ in $10 \% \mathrm{i}$-PrOH in THF for $16 \mathrm{~h}$ to provide $3 \mathbf{b}(45 \mathrm{mg}, 0.145 \mathrm{mmol}, 59 \%$ yield, $>99: 1 \mathrm{dr})$ as a colorless oil. The crude dr was determined by LCMS (XIC) from the crude reaction mixture after reduction to the alcohol 13b using $\mathrm{NaBH}_{4}$ in $\mathrm{MeOH}$ on an analytical scale $\left(t_{\mathrm{R}}\right.$ major $=2.64 \mathrm{~min} ; t_{\mathrm{R}}$ minor $=2.56$ min, 93:7 dr). ${ }^{1} \mathrm{H}$ NMR $\left(600 \mathrm{MHz}, \mathrm{CDCl}_{3}\right) \delta 9.50(\mathrm{~d}, J=5.1 \mathrm{~Hz}, 1 \mathrm{H}), 7.35-7.32(\mathrm{~m}, 2 \mathrm{H}), 7.29-7.25(\mathrm{~m}, 3 \mathrm{H}), 4.01-3.97(\mathrm{~m}, 1 \mathrm{H})$, $3.92-3.62(\mathrm{~m}, 4 \mathrm{H}), 1.57(\mathrm{br}, 3 \mathrm{H}), 1.53-1.49(\mathrm{~m}, 9 \mathrm{H}) ;{ }^{13} \mathrm{C} \mathrm{NMR}\left(151 \mathrm{MHz}, \mathrm{CDCl}_{3}\right) \delta 198.7-198.0(\mathrm{~m}), 154.2(\mathrm{~d}, J=15.6$ $\mathrm{Hz}), 140.1$ (d, $J=26.2 \mathrm{~Hz}), 129.0,127.8,126.3,126.2,104.1-102.0(\mathrm{~m}), 80.5,80.5,55.6,55.0,50.8-50.2$ (m), $28.5,28.4,23.3$ - $23.2(\mathrm{~m}) .{ }^{19} \mathrm{~F}$ NMR $\left(471 \mathrm{MHz}, \mathrm{CDCl}_{3}\right) \delta-175.84,-176.79$ (conformers). HRMS-ESI: $m / z$ for $\mathrm{C}_{13} \mathrm{H}_{15} \mathrm{FNO}_{3}\left[\mathrm{MH}^{+}-t \mathrm{Bu}^{\mathrm{c}} \mathrm{calcd}\right.$. 252.1030; found 252.1026. $[\alpha]_{\mathrm{D}}^{22}=-30.7^{\circ}\left(c=0.088, \mathrm{CHCl}_{3}\right)$.

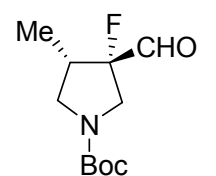

tert-Butyl (3S,4S)-3-fluoro-3-formyl-4-methylpyrrolidine-1-carboxylate (2c) In accordance with the general procedure, 1c $(222 \mathrm{mg}, 1.04 \mathrm{mmol})$ was reacted with $(R)-7(62 \mathrm{mg}, 0.104 \mathrm{mmol}, 10 \mathrm{~mol} \%)$ and NFSI (394 mg, $1.25 \mathrm{mmol})$ in MTBE for $16 \mathrm{~h}$ to provide $2 \mathrm{c}(210 \mathrm{mg}, 0.908 \mathrm{mmol}, 87 \%$ yield, $94: 6 \mathrm{dr})$ as a colorless oil. The crude dr was determined by LCMS (XIC) after reduction to the alcohol 11c using $\mathrm{NaBH}_{4}$ in $\mathrm{MeOH}$ on an analytical scale $\left(t_{\mathrm{R}}\right.$ major $=2.10 \mathrm{~min} ; t_{\mathrm{R}}$ minor $\left.=1.99 \mathrm{~min}, 97: 3 \mathrm{dr}\right)$. The product can be isolated and handled as 2c. ${ }^{1} \mathrm{H}$ NMR $\left(600 \mathrm{MHz}, \mathrm{CDCl}_{3}\right) \delta 9.84-9.82(\mathrm{~m}, 1 \mathrm{H}), 3.86-3.44(\mathrm{~m}, 3 \mathrm{H}), 3.18-3.02(\mathrm{~m}, 1 \mathrm{H}), 2.70-2.10(\mathrm{~m}, 1 \mathrm{H}), 1.49-$ $1.42(\mathrm{~m}, 9 \mathrm{H}), 1.10-0.97(\mathrm{~m}, 3 \mathrm{H})$.

Due to hydrate formation, $2 \mathbf{c}$ was additionally characterized and the purity verified after reduction to the corresponding alcohol $11 \mathrm{c}$ in accordance with the general procedure. ${ }^{1} \mathrm{H} \mathrm{NMR}\left(600 \mathrm{MHz}, \mathrm{CDCl}_{3}\right) \delta 3.93-3.85(\mathrm{~m}, 1 \mathrm{H}), 3.76-3.51(\mathrm{~m}, 4 \mathrm{H}), 3.16-$ $3.08(\mathrm{~m}, 1 \mathrm{H}), 2.35-1.97(\mathrm{~m}, 2 \mathrm{H}), 1.46(\mathrm{~s}, 9 \mathrm{H}), 1.08-1.05(\mathrm{~m}, 3 \mathrm{H}) ;{ }^{13} \mathrm{C} \mathrm{NMR}\left(151 \mathrm{MHz}, \mathrm{CDCl}_{3}\right) \delta 154.2,104.0-100.8(\mathrm{~m})$, 79.6, 64.2 - $63.5(\mathrm{~m}), 54.6-53.8(\mathrm{~m}), 38.6-37.1(\mathrm{~m}), 28.5,10.0-9.8(\mathrm{~m}) .{ }^{19} \mathrm{~F}$ NMR $\left(471 \mathrm{MHz}, \mathrm{CDCl}_{3}\right) \delta-177.08,-177.21$. HRMS-ESI: $m / z$ for $\mathrm{C}_{7} \mathrm{H}_{11} \mathrm{FNO}_{3}\left[\mathrm{MH}^{+}\right]$calcd. 234.1500; found 234.1498. $[\alpha]_{\mathrm{D}}^{22}=+18.5^{\circ}\left(c=0.265, \mathrm{CHCl}_{3}\right)$. 


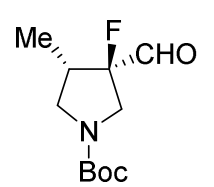

tert-Butyl (3R,4S)-3-fluoro-3-formyl-4-methylpyrrolidine-1-carboxylate (3c) In accordance with the general procedure, 1c (135 mg, $0.633 \mathrm{mmol})$ was reacted with $(S)-8(22 \mathrm{mg}, 0.063 \mathrm{mmol}, 10 \mathrm{~mol} \%)$ and NFSI $(240 \mathrm{mg}$, $0.76 \mathrm{mmol}$ ) in $10 \% \mathrm{i}$-PrOH in THF for $18 \mathrm{~h}$ to provide $3 \mathrm{c}$ (91 mg, $0.393 \mathrm{mmol}, 62 \%$ yield, 90:10 dr) as a yellow oil. The crude dr was determined by LCMS (XIC) after reduction to the alcohol $\mathbf{1 3 c}$ using $\mathrm{NaBH}_{4}$ in $\mathrm{MeOH}$ on an analytical scale $\left(t_{\mathrm{R}}\right.$ major $=2.01 \mathrm{~min} ; t_{\mathrm{R}}$ minor $\left.=2.10 \mathrm{~min}, 87: 13 \mathrm{dr}\right)$. The product $3 \mathbf{c}$ can be isolated and handled at the aldehyde stage. ${ }^{1} \mathrm{H}$ NMR $\left(600 \mathrm{MHz}, \mathrm{CDCl}_{3}\right) \delta 9.82-9.78(\mathrm{~m}, 1 \mathrm{H}), 3.90-3.44(\mathrm{~m}, 3 \mathrm{H}), 3.35-3.17$ $(\mathrm{m}, 1 \mathrm{H}), 2.67-2.34(\mathrm{~m}, 1 \mathrm{H}), 1.47-1.43(\mathrm{~m}, 9 \mathrm{H}), 1.07-0.96(\mathrm{~m}, 3 \mathrm{H}) .{ }^{13} \mathrm{C} \mathrm{NMR}\left(151 \mathrm{MHz}, \mathrm{CDCl}_{3}\right) \delta 199.2,198.9,198.3-$ $197.5(\mathrm{~m}), 154.6-154.2(\mathrm{~m}), 129.3-128.6(\mathrm{~m}), 106.0-103.3(\mathrm{~m}), 89.8-89.6(\mathrm{~m}), 80.3-80.1(\mathrm{~m}), 52.7-50.5(\mathrm{~m}), 41.1-$ $40.7(\mathrm{~m}), 40.1-39.8(\mathrm{~m}), 28.5,28.4,14.0-13.7(\mathrm{~m})$ (conformers and hydrate formation). ${ }^{19} \mathrm{~F} \mathrm{NMR}\left(471 \mathrm{MHz}, \mathrm{CDCl}_{3}\right) \delta-$ 160.84, -162.56. HRMS-ESI: $m / z$ for $\mathrm{C}_{7} \mathrm{H}_{11} \mathrm{FNO}_{3}\left[\mathrm{MH}^{+}-t \mathrm{Bu}\right]$ calcd. 176.0717; found 176.0715. $[\alpha]_{\mathrm{D}}^{22}=-2.7^{\circ}(c=0.488$, $\left.\mathrm{CHCl}_{3}\right)$.

Due to hydrate formation, $3 \mathbf{c}$ was additionally characterized and the purity verified after reduction to the corresponding alcohol $13 \mathbf{c}$ in accordance with the general procedure. ${ }^{1} \mathrm{H} \mathrm{NMR}\left(600 \mathrm{MHz}, \mathrm{CDCl}_{3}\right) \delta 3.87-3.64(\mathrm{~m}, 3 \mathrm{H}), 3.63-3.41(\mathrm{~m}, 2 \mathrm{H}), 3.30-$ $3.18(\mathrm{~m}, 1 \mathrm{H}), 2.54-2.43(\mathrm{~m}, 1 \mathrm{H}), 1.46(\mathrm{~s}, 9 \mathrm{H}), 1.27-1.24(\mathrm{~m}, 1 \mathrm{H}), 1.08-1.00(\mathrm{~m}, 3 \mathrm{H}) ;{ }^{13} \mathrm{C} \mathrm{NMR}\left(151 \mathrm{MHz}, \mathrm{CDCl}_{3}\right) \delta 154.8$, 154.6, $106.6-104.4(\mathrm{~m}), 79.8,79.7,62.7(\mathrm{~m}), 52.5-51.6(\mathrm{~m}), 51.6-50.6(\mathrm{~m}), 38.7(\mathrm{~m}), 28.5,15.5(\mathrm{~m})$.

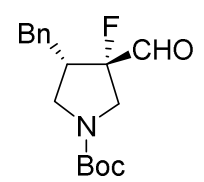

tert-Butyl (3S,4S)-4-benzyl-3-fluoro-3-formylpyrrolidine-1-carboxylate (2d) In accordance with the general procedure, 1d (157 mg, $0.543 \mathrm{mmol})$ was reacted with $(R)-7(32 \mathrm{mg}, 0.054 \mathrm{mmol}, 10 \mathrm{~mol} \%)$ and NFSI (212 $\mathrm{mg}, 0.65 \mathrm{mmol})$ in MTBE for $16 \mathrm{~h}$ to provide $2 \mathrm{~d}(126 \mathrm{mg}, 0.410 \mathrm{mmol}, 76 \%$ yield, $>99: 1 \mathrm{dr})$ as a colorless oil. The crude dr was determined by LCMS (XIC) after reduction to the alcohol 11d using $\mathrm{NaBH}_{4}$ in $\mathrm{MeOH}$ on an analytical scale $\left(t_{\mathrm{R}}\right.$ major $=2.63 \mathrm{~min} ; t_{\mathrm{R}}$ minor $\left.=2.57 \mathrm{~min}, 98: 2 \mathrm{dr}\right) .{ }^{1} \mathrm{H} \mathrm{NMR}\left(600 \mathrm{MHz}, \mathrm{CDCl}_{3}\right) \delta 9.31-9.27$

$(\mathrm{m}, 1 \mathrm{H}), 7.32-7.14(\mathrm{~m}, 5 \mathrm{H}), 3.83-3.57(\mathrm{~m}, 3 \mathrm{H}), 3.34-3.27(\mathrm{~m}, 1 \mathrm{H}), 2.98-2.60(\mathrm{~m}, 3 \mathrm{H}), 1.47-1.41(\mathrm{~m}, 9 \mathrm{H}) ;{ }^{13} \mathrm{C} \mathrm{NMR}(151$ $\left.\mathrm{MHz}, \mathrm{CDCl}_{3}\right) \delta 198.2(\mathrm{~d}, J=42.8 \mathrm{~Hz}), 153.8(\mathrm{~d}, J=30.5 \mathrm{~Hz}), 138.3,128.9,127.17,127.15,106.5-102.4(\mathrm{~m}), 80.2,55.0-54.4$ (m), $50.4-49.8$ (m), 50.0, 49.7, $32.3-32.1$ (m), 28.44, 28.39. ${ }^{19} \mathrm{~F}$ NMR (471 MHz, $\mathrm{CDCl}_{3}$ ) $\delta-180.51,-180.95$ (two conformers); HRMS-ESI: $m / z$ for $\mathrm{C}_{13} \mathrm{H}_{15} \mathrm{FNO}_{3}\left[\mathrm{MH}^{+}-t \mathrm{Bu}\right]$ calcd. 252.1030; found 252.1026. $[\alpha]_{\mathrm{D}}{ }^{22}=+31.9^{\circ}\left(c=2.64, \mathrm{CHCl}_{3}\right)$.

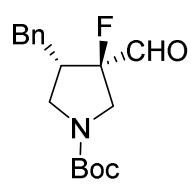

tert-Butyl (3R,4S)-4-benzyl-3-fluoro-3-formylpyrrolidine-1-carboxylate (3d) In accordance with the general procedure, $1 \mathbf{d}(189 \mathrm{mg}, 0.653 \mathrm{mmol})$ was reacted with $(S)-8(23 \mathrm{mg}, 0.065 \mathrm{mmol}, 10 \mathrm{~mol} \%)$ and NFSI (255 $\mathrm{mg}, 0.784 \mathrm{mmol})$ in $10 \% \mathrm{i}$-PrOH in THF for $18 \mathrm{~h}$ to provide $3 \mathrm{~d}(102 \mathrm{mg}, 0.332 \mathrm{mmol}, 51 \%$ yield, $98: 2 \mathrm{dr})$ as a yellow oil. The crude dr was determined by LCMS (XIC) after reduction to the alcohol $\mathbf{1 3 d}$ using $\mathrm{NaBH}_{4}$ in $\mathrm{MeOH}$ on an analytical scale $\left(t_{\mathrm{R}}\right.$ major $=2.54 \mathrm{~min} ; t_{\mathrm{R}}$ minor $\left.=2.61 \mathrm{~min}, 94: 6 \mathrm{dr}\right) .{ }^{1} \mathrm{H} \mathrm{NMR}\left(600 \mathrm{MHz}, \mathrm{CDCl}_{3}\right)$ $\delta 9.87-9.83(\mathrm{~m}, 1 \mathrm{H}), 7.34-7.19(\mathrm{~m}, 3 \mathrm{H}), 7.13-7.10(\mathrm{~m}, 2 \mathrm{H}), 4.01-3.85(\mathrm{~m}, 1 \mathrm{H}), 3.67-3.48(\mathrm{~m}, 2 \mathrm{H}), 3.42-3.29(\mathrm{~m}, 1 \mathrm{H})$, $2.90-2.77(\mathrm{~m}, 2 \mathrm{H}), 2.46-2.39(\mathrm{~m}, 1 \mathrm{H}), 1.48-1.43(\mathrm{~m}, 9 \mathrm{H}) ;{ }^{13} \mathrm{C}$ NMR $\left(151 \mathrm{MHz}, \mathrm{CDCl}_{3}\right) \delta 198.4(\mathrm{~d}, J=43.3 \mathrm{~Hz}), 154.2(\mathrm{~d}, J$ $=31.5 \mathrm{~Hz}), 138.0(\mathrm{~d}, J=22.0 \mathrm{~Hz}), 128.81,128.79,126.9,104.7-102.5(\mathrm{~m}), 52.0-51.3(\mathrm{~m}), 80.3,49.1,48.9,48.4-47.5(\mathrm{~m})$, $33.6(\mathrm{~d}, J=10.8 \mathrm{~Hz}), 28.4 ;{ }^{19} \mathrm{~F}$ NMR $\left(471 \mathrm{MHz}, \mathrm{CDCl}_{3}\right) \delta-161.81,-162.56,-167.82,-168.11,-169.29$, -169.61. (conformers and partial hydrate formation). HRMS-ESI: $m / z$ for $\mathrm{C}_{13} \mathrm{H}_{15} \mathrm{FNO}_{3}\left[\mathrm{MH}^{+}-t \mathrm{Bu}\right]$ calcd. 252.1030; found 252.1037. $[\alpha]_{\mathrm{D}}^{22}=+35^{\circ}(c=$ $\left.1.33, \mathrm{CHCl}_{3}\right)$.

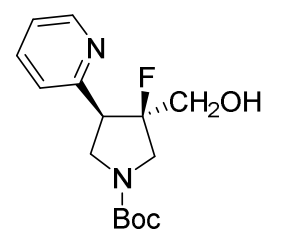

tert-Butyl (3R,4S)-3-fluoro-3-formyl-4-(pyridin-2-yl)pyrrolidine-1-carboxylate (11e) In accordance with the general procedure, 1e $(31 \mathrm{mg}, 0.112 \mathrm{mmol})$ was reacted with $(S)-7(13 \mathrm{mg}, 0.022 \mathrm{mmol}, 20$ mol\%) and NFSI (44 mg, $0.135 \mathrm{mmol})$ in MTBE for $16 \mathrm{~h}$. Subsequently, MeOH (3 mL) was added followed by $\mathrm{NaBH}_{4}(13 \mathrm{mg}, 0.337 \mathrm{mmol}, 3$ equiv) and the resulting mixture was stirred for $30 \mathrm{~min}$. Half sat. brine $(1.5 \mathrm{~mL})$ was added followed by a 1:1 mixture of THF/EtOAc $(4 \mathrm{~mL})$ and the phases were separated. The aqueous phase was extracted with a 1:1 mixture of THF/EtOAc $(2 \times 4 \mathrm{~mL})$ and the organic phases combined, dried over $\mathrm{MgSO}_{4}$, filtered and concentrated in vacuo to provide a crude oil that was purified using silica gel chromatography to furnish 11e $(26.3 \mathrm{mg}, 0.089 \mathrm{mmol}, 79 \%$ yield, $>99: 1 \mathrm{dr})$ as a colorless oil. The crude dr was determined by LCMS $(X I C)\left(t_{\mathrm{R}}\right.$ major $=1.46 \mathrm{~min} ; t_{\mathrm{R}}$ minor $\left.=1.66 \mathrm{~min}, 95: 5 \mathrm{dr}\right) .{ }^{1} \mathrm{H}$ NMR $\left(600 \mathrm{MHz}, \mathrm{CDCl}_{3}\right) \delta 8.57-8.52(\mathrm{~m}, 1 \mathrm{H}), 7.77-7.71$ $(\mathrm{m}, 1 \mathrm{H}), 7.32-7.25(\mathrm{~m}, 2 \mathrm{H}), 4.12-3.99(\mathrm{~m}, 1 \mathrm{H}), 3.93-3.88(\mathrm{~m}, 1 \mathrm{H}), 3.86-3.68(\mathrm{~m}, 5 \mathrm{H}), 1.50(\mathrm{~s}, 9 \mathrm{H}) ;{ }^{13} \mathrm{C} \mathrm{NMR}(151 \mathrm{MHz}$, $\left.\mathrm{CDCl}_{3}\right) \delta 154.6-154.2(\mathrm{~m}), 148.74,148.6,137.4,137.2,123.1,123.0,122.8,103.2-101.1(\mathrm{~m}), 80.1,62.6-62.1(\mathrm{~m}), 54.8-$ $54.1(\mathrm{~m}), 50.8-49.9(\mathrm{~m}), 48.1,47.6,28.5 .{ }^{19} \mathrm{~F}$ NMR $\left(471 \mathrm{MHz}, \mathrm{CDCl}_{3}\right) \delta-169.25,-169.56$ (two conformers of the major isomer). HRMS-ESI: $m / z$ for $\mathrm{C}_{15} \mathrm{H}_{22} \mathrm{FN}_{2} \mathrm{O}_{3}\left[\mathrm{MH}^{+}\right]$calcd. 297.1609; found 297.1612. $[\alpha]_{\mathrm{D}}^{22}=+56.8^{\circ}\left(c=0.176, \mathrm{CHCl}_{3}\right)$. 


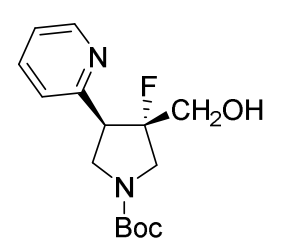

tert-Butyl (3S,4S)-3-fluoro-3-(hydroxymethyl)-4-(pyridin-2-yl)pyrrolidine-1-carboxylate (13e) In accordance with the general procedure, 1 e $(71.4 \mathrm{mg}, 0.258 \mathrm{mmol})$ was reacted with $(R)-8(18 \mathrm{mg}, 0.052$ mmol, $20 \mathrm{~mol} \%$ ) and NFSI (101 mg, $0.31 \mathrm{mmol})$ in $10 \% i$-PrOH in THF for $20 \mathrm{~h}$. Subsequently, MeOH $(5 \mathrm{~mL})$ was added followed by $\mathrm{NaBH}_{4}(29 \mathrm{mg}, 0.775 \mathrm{mmol}, 3$ equiv) and the resulting mixture was stirred for $30 \mathrm{~min}$. Half sat. brine $(2 \mathrm{~mL})$ was added followed by a $1: 1$ mixture of THF/EtOAc $(6 \mathrm{~mL})$ and the phases were separated. The aqueous phase was extracted with a 1:1 mixture of THF/EtOAc $(2 \times 6 \mathrm{~mL})$ and the organic phases combined, dried over $\mathrm{MgSO}_{4}$, filtered and concentrated in vacuo to provide a crude oil that was purified using silica gel chromatography to furnish $13 \mathrm{e}(33.5 \mathrm{mg}, 0.113 \mathrm{mmol}, 44 \%$ yield, $>99: 1)$ as a colorless oil. The crude dr was determined by LCMS (XIC) $\left(t_{\mathrm{R}}\right.$ major $=1.66 \mathrm{~min} ; t_{\mathrm{R}}$ minor $\left.=1.47 \mathrm{~min}, 99: 1 \mathrm{dr}\right) .{ }^{1} \mathrm{H} \mathrm{NMR}\left(600 \mathrm{MHz}, \mathrm{CDCl}_{3}\right) \delta 8.58-8.54(\mathrm{~m}$, $1 \mathrm{H}), 7.76-7.72(\mathrm{~m}, 1 \mathrm{H}), 7.29-7.24(\mathrm{~m}, 2 \mathrm{H}), 4.79-4.57(\mathrm{~m}, 1 \mathrm{H}), 3.98-3.84(\mathrm{~m}, 3 \mathrm{H}), 3.71-3.59(\mathrm{~m}, 2 \mathrm{H}), 3.53-3.42(\mathrm{~m}$, $1 \mathrm{H}), 3.36-3.24(\mathrm{~m}, 1 \mathrm{H}), 1.52-1.48(\mathrm{~m}, 9 \mathrm{H}) ;{ }^{13} \mathrm{C} \mathrm{NMR}\left(151 \mathrm{MHz}, \mathrm{CDCl}_{3}\right) \delta 157.6-157.1(\mathrm{~m}), 154.4,149.34,149.28,138.0$, $137.9,122.9,122.10,122.05,80.163 .2(\mathrm{~d}), 52.8-51.7(2 \mathrm{x} \mathrm{m}), 49.6,49.1,28.52,28.50 .{ }^{19} \mathrm{~F} \mathrm{NMR}\left(471 \mathrm{MHz}, \mathrm{CDCl}_{3}\right) \delta-$ 150.58, -151.58 (two conformers of the major isomer). HRMS-ESI: $m / z$ for $\mathrm{C}_{15} \mathrm{H}_{22} \mathrm{FN}_{2} \mathrm{O}_{3}\left[\mathrm{MH}^{+}\right.$] calcd. 297.1609; found 297.1608. $[\alpha]_{\mathrm{D}}^{22}=+59.5^{\circ}\left(c=0.387, \mathrm{CHCl}_{3}\right)$.

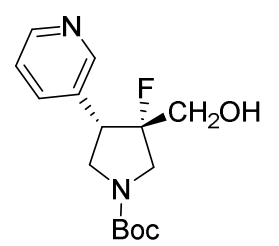

tert-Butyl (3S,4S)-3-fluoro-3-formyl-4-(pyridin-3-yl)pyrrolidine-1-carboxylate (11f) In accordance with the general procedure, $\mathbf{1 f}(83 \mathrm{mg}, 0.300 \mathrm{mmol})$ was reacted with $(R)-7(36 \mathrm{mg}, 0.06 \mathrm{mmol}, 20 \mathrm{~mol} \%)$ and NFSI (117 mg, $0.36 \mathrm{mmol})$ in MTBE for $16 \mathrm{~h}$. Subsequently, MeOH (3 mL) was added followed by $\mathrm{NaBH}_{4}$ (34 mg, $0.900 \mathrm{mmol}, 3$ equiv) and the resulting mixture was stirred for $30 \mathrm{~min}$. Half sat. brine (1.5 $\mathrm{mL})$ was added followed by a 1:1 mixture of THF/EtOAc $(4 \mathrm{~mL})$ and the phases were separated. The aqueous phase was extracted with a 1:1 mixture of THF/EtOAc $(2 \times 4 \mathrm{~mL})$ and the organic phases combined, dried over $\mathrm{MgSO}_{4}$, filtered and concentrated in vacuo to provide a crude oil that was purified using silica gel chromatography to furnish $11 \mathrm{f}(64.4 \mathrm{mg}, 0.216 \mathrm{mmol}, 72 \%$ yield, $96: 4 \mathrm{dr})$ as a colorless oil. The crude dr was determined by LCMS $(\mathrm{UV})\left(t_{\mathrm{R}}\right.$ major $=1.32 \mathrm{~min} ; t_{\mathrm{R}}$ minor $\left.=1.34 \mathrm{~min}, 97: 3 \mathrm{dr}\right) .{ }^{1} \mathrm{H}$ NMR $\left(600 \mathrm{MHz}, \mathrm{CDCl}_{3}\right) \delta 8.53-8.42(\mathrm{~m}, 2 \mathrm{H}), 7.77-7.71$ $(\mathrm{m}, 1 \mathrm{H}), 7.30-7.27(\mathrm{~m}, 1 \mathrm{H}), 4.82(\mathrm{br}, 1 \mathrm{H}), 3.98-3.45(\mathrm{~m}, 7 \mathrm{H}), 1.49-1.44(\mathrm{~m}, 9 \mathrm{H}) ;{ }^{13} \mathrm{C} \mathrm{NMR}\left(151 \mathrm{MHz}, \mathrm{CDCl}_{3}\right) \delta 154.6(\mathrm{~d}, J$ $=3.4 \mathrm{~Hz}), 150.6,150.5,148.7,148.6,137.6,131.1,130.9,123.9,123.8,103.34-101.32(\mathrm{~m}), 80.33,80.20,61.2-60.6(\mathrm{~m}), 54.4$ - $53.7(\mathrm{~m}), 50.3,49.7,46.2$ - $45.2(\mathrm{~m}), 28.6 .{ }^{19} \mathrm{~F}$ NMR (471 MHz, $\mathrm{CDCl}_{3}$ ) $\delta-152.92$ (trace amount of minor isomer), -170.19, 170.28 (two conformers of the major isomer). HRMS-ESI: $m / z$ for $\mathrm{C}_{15} \mathrm{H}_{22} \mathrm{FN}_{2} \mathrm{O}_{3}\left[\mathrm{MH}^{+}\right]$calcd. 297.1609; found 297.1608. [ $\left.\alpha\right]_{\mathrm{D}}{ }^{22}$ $=-44.9^{\circ}\left(c=1.60, \mathrm{CHCl}_{3}\right)$.

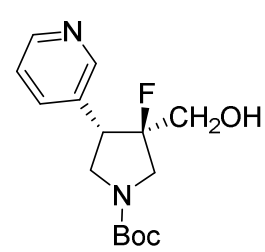

tert-Butyl (3R,4S)-3-fluoro-3-(hydroxymethyl)-4-(pyridin-3-yl)pyrrolidine-1-carboxylate (13f) In accordance with the general procedure, 1 f $(83 \mathrm{mg}, 0.300 \mathrm{mmol})$ was reacted with $(S)-\mathbf{8}(21 \mathrm{mg}, 0.06$ $\mathrm{mmol}, 20 \mathrm{~mol} \%$ ) and NFSI (117 mg, $0.36 \mathrm{mmol}$ in 10\% $i$-PrOH in THF for $20 \mathrm{~h}$. Subsequently, MeOH (3 $\mathrm{mL}$ ) was added followed by $\mathrm{NaBH}_{4}(34 \mathrm{mg}, 0.900 \mathrm{mmol}, 3$ equiv) and the resulting mixture was stirred for $30 \mathrm{~min}$. Half sat. brine $(1.5 \mathrm{~mL})$ was added followed by a 1:1 mixture of THF/EtOAc $(4 \mathrm{~mL})$ and the phases were separated. The aqueous phase was extracted with a 1:1 mixture of THF/EtOAc (2 x $4 \mathrm{~mL})$ and the organic phases combined, dried over $\mathrm{MgSO}_{4}$, filtered and concentrated in vacuo to provide a crude oil that was purified using silica gel chromatography to provide the stereopure fluoroalcohol though contaminated by the catalyst. The catalyst was removed using preparative LCMS to yield $\mathbf{1 3 f}(58 \mathrm{mg}, 0.196 \mathrm{mmol}, 65 \%$ yield, $>99: 1 \mathrm{dr})$ as a colorless oil. The crude dr was determined by LCMS $(\mathrm{UV})\left(t_{\mathrm{R}}\right.$ major $=1.34 \mathrm{~min} ; t_{\mathrm{R}}$ minor $\left.=1.33 \mathrm{~min}, 98: 2 \mathrm{dr}\right) .{ }^{1} \mathrm{H} \mathrm{NMR}\left(600 \mathrm{MHz}, \mathrm{CDCl}_{3}\right) \delta 8.53$ $-8.49(\mathrm{~m}, 2 \mathrm{H}), 7.57-7.53(\mathrm{~m}, 1 \mathrm{H}), 7.30-7.27(\mathrm{~m}, 1 \mathrm{H}), 4.02-3.95(\mathrm{~m}, 1 \mathrm{H}), 3.81-3.61(\mathrm{~m}, 3 \mathrm{H}), 3.59-3.30(\mathrm{~m}, 3 \mathrm{H}), 1.51-$ $1.48(\mathrm{~m}, 9 \mathrm{H}) ;{ }^{13} \mathrm{C} \mathrm{NMR}\left(151 \mathrm{MHz}, \mathrm{CDCl}_{3}\right) \delta 154.5(\mathrm{~d}, J=17.6 \mathrm{~Hz}), 149.52,149.44,149.12,135.31,135.23,134.6-134.2(\mathrm{~m})$, 124.15, $106.2-104.3(\mathrm{~m}), 80.62,62.9-62.4(\mathrm{~m}), 52.1-51.5(\mathrm{~m}), 51.22,50.60,48.4-47.3(\mathrm{~m}) 28.65 .{ }^{19} \mathrm{~F} \mathrm{NMR}(471 \mathrm{MHz}$, $\left.\mathrm{CDCl}_{3}\right) \delta-153.25,-153.31$ (two conformers of the major isomer). HRMS-ESI: $m / z$ for $\mathrm{C}_{15} \mathrm{H}_{22} \mathrm{FN}_{2} \mathrm{O}_{3}\left[\mathrm{MH}^{+}\right]$calcd. 297.1609; found 297.1611 .

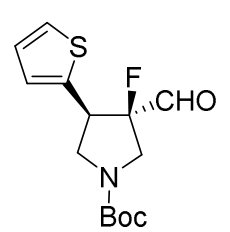

tert-Butyl (3R,4R)-3-fluoro-3-formyl-4-(thiophen-2-yl)pyrrolidine-1-carboxylate (2g) In accordance with the general procedure, $1 \mathrm{~g}(132.2 \mathrm{mg}, 0.470 \mathrm{mmol})$ was reacted with $(S)-7(28 \mathrm{mg}, 0.047 \mathrm{mmol}, 10 \mathrm{~mol} \%)$ and NFSI (183 mg, $0.564 \mathrm{mmol}$ ) in MTBE for $14 \mathrm{~h}$ to provide $2 \mathrm{~g}$ (117 mg, $0.391 \mathrm{mmol}, 83 \%$ yield, 89:11 dr) as a colorless oil. The crude dr was determined by LCMS (XIC) after reduction to the alcohol $11 \mathrm{~g}$ using $\mathrm{NaBH}_{4}$ in $\mathrm{MeOH}$ on an analytical scale $\left(t_{\mathrm{R}}\right.$ major $=2.45 \mathrm{~min} ; t_{\mathrm{R}}$ minor $\left.=2.38 \mathrm{~min}, 89: 11 \mathrm{dr}\right) .{ }^{1} \mathrm{H} \mathrm{NMR}(600 \mathrm{MHz}$, $\left.\mathrm{CDCl}_{3}\right) \delta 9.75-9.71(\mathrm{~m}, 1 \mathrm{H}), 7.28-7.26(\mathrm{~m}, 1 \mathrm{H}), 6.99-6.94(\mathrm{~m}, 2 \mathrm{H}), 4.10-3.65(\mathrm{~m}, 5 \mathrm{H}), 1.49-1.42(\mathrm{~m}$, 9H); ${ }^{13} \mathrm{C}$ NMR $\left(151 \mathrm{MHz}, \mathrm{CDCl}_{3}\right) \delta 198.9(\mathrm{~d}, J=42.9 \mathrm{~Hz}), 153.8(\mathrm{~d}, J=27.3 \mathrm{~Hz}), 134.0(\mathrm{~d}, J=5.8 \mathrm{~Hz}), 127.3,127.21,127.19$, 126.98, 126.95, 126.7, 125.8, 125.7, 104.6-102.4 (m), 80.6, 54.3-53.8 (m), 51.0, 50.5, $47.2-46.4(\mathrm{~m}), 28.5,28.4$. 
For additional characterization, $\mathbf{2 g}$ was reduced to the corresponding alcohol $\mathbf{1 1 g}$ in accordance with the general procedure. ${ }^{1} \mathrm{H}$ NMR (600 MHz, $\left.\mathrm{CDCl}_{3}\right) \delta 7.28-7.26(\mathrm{~m}, 1 \mathrm{H}), 7.02-6.98(\mathrm{~m}, 2 \mathrm{H}), 4.05-3.62(\mathrm{~m}, 7 \mathrm{H}), 1.97-1.82(\mathrm{br}, 1 \mathrm{H}), 1.49-1.46(\mathrm{~m}$, $9 \mathrm{H}) ;{ }^{13} \mathrm{C} \mathrm{NMR}\left(151 \mathrm{MHz}, \mathrm{CDCl}_{3}\right) \delta 135.8,127.1,126.7,125.4,80.0,63.3-62.4(\mathrm{~m}), 54.4-53.4(\mathrm{~m}), 51.7,51.1,44.7-43.8$ (m), 28.5. ${ }^{19} \mathrm{~F}$ NMR $\left(471 \mathrm{MHz}, \mathrm{CDCl}_{3}\right) \delta-155.65,-155.71$ (two conformers from the trace amount of minor isomer), -170.09, 170.15 (two conformers of the major isomer). HRMS-ESI: $m / z \mathrm{C}_{14} \mathrm{H}_{21} \mathrm{FNO}_{3} \mathrm{~S}\left[\mathrm{MH}^{+}\right]$calcd. 302.1221 ; found 302.1216 . [ $\left.\alpha\right]_{\mathrm{D}}{ }^{22}=$ $+37.2^{\circ}\left(c=0.223, \mathrm{CHCl}_{3}\right)$.

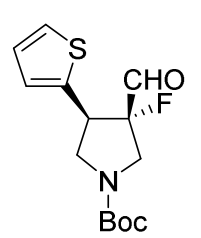

tert-Butyl (3S,4R)-3-fluoro-3-formyl-4-(thiophen-2-yl)pyrrolidine-1-carboxylate (3g) In accordance with the general procedure, $\mathbf{1 g}(136.3 \mathrm{mg}, 0.484 \mathrm{mmol})$ was reacted with $(R)-8(34 \mathrm{mg}, 0.097 \mathrm{mmol}, 20 \mathrm{~mol} \%)$ and NFSI $(189 \mathrm{mg}, 0.581 \mathrm{mmol})$ in $10 \% \mathrm{i}$-PrOH in THF for $18 \mathrm{~h}$ to provide $\mathbf{3 g}(106 \mathrm{mg}, 0.354 \mathrm{mmol}, 73 \%$ yield, $99: 1 \mathrm{dr})$ as a yellow oil. The crude dr was determined by LCMS (XIC) after reduction to the alcohol $\mathbf{1 3 g}$ using $\mathrm{NaBH}_{4}$ in $\mathrm{MeOH}$ on an analytical scale $\left(t_{\mathrm{R}}\right.$ major $=2.38 \mathrm{~min} ; t_{\mathrm{R}}$ minor $\left.=2.44 \mathrm{~min}, 98: 2 \mathrm{dr}\right) .{ }^{1} \mathrm{H} \mathrm{NMR}\left(600 \mathrm{MHz}, \mathrm{CDCl}_{3}\right) \delta$ $9.49(\mathrm{~d}, J=3.2 \mathrm{~Hz}, 1 \mathrm{H}), 7.26-7.23(\mathrm{~m}, 1 \mathrm{H}), 6.98-6.88(\mathrm{~m}, 2 \mathrm{H}), 4.13-3.58(\mathrm{~m}, 5 \mathrm{H}), 1.52-1.48(\mathrm{~m}, 9 \mathrm{H}) ;{ }^{13} \mathrm{C}$ NMR $\left(151 \mathrm{MHz}, \mathrm{CDCl}_{3}\right) \delta 196.8$ - $196.0(\mathrm{~m}), 154.6$ - $153.9(\mathrm{~m}), 139.9-139.6(\mathrm{~m}), 136.3-136.2(\mathrm{~m}), 127.3$, $126.90,126.87,126.4,126.4,125.7,124.9,106.3-101.6(\mathrm{~m}), 89.7,89.5,80.7,80.22,80.20,52.6-50.4(\mathrm{~m}), 47.9-46.6(\mathrm{~m})$, $46.2-44.9(\mathrm{~m}), 28.52,28.48,28.43$. Partial hydrate formation and mixture of conformers.

For additional characterization, $\mathbf{3 g}$ was reduced to the corresponding alcohol $\mathbf{1 3 g}$ in accordance with the general procedure. ${ }^{1} \mathrm{H}$ NMR $\left(600 \mathrm{MHz}, \mathrm{CDCl}_{3}\right) \delta 7.23-7.21(\mathrm{~m}, 1 \mathrm{H}), 6.98-6.95(\mathrm{~m}, 1 \mathrm{H}), 6.94-6.91(\mathrm{~m}, 1 \mathrm{H}), 3.97-3.90(\mathrm{~m}, 1 \mathrm{H}), 3.89-3.48(\mathrm{~m}$, $6 \mathrm{H}), 1.82(\mathrm{br}, 1 \mathrm{H}), 1.53-1.49(\mathrm{~m}, 9 \mathrm{H}) ;{ }^{13} \mathrm{C} \mathrm{NMR}\left(151 \mathrm{MHz}, \mathrm{CDCl}_{3}\right) \delta 154.3,127.0,125.8,125.8,124.9,104.5,80.2,63.3-$ 62.7 (m), 52.06, 51.7, 51.5, 51.4, 51.3, 51.1, $46.2-45.2(\mathrm{~m}), 28.48,28.46 .{ }^{19} \mathrm{~F}$ NMR $\left(471 \mathrm{MHz}, \mathrm{CDCl}_{3}\right) \delta-155.67,-155.71$ (two conformers of the major isomer), -170.13 (trace amount of minor isomer). HRMS-ESI: $m / z \mathrm{C}_{14} \mathrm{H}_{21} \mathrm{FNO}_{3} \mathrm{~S}\left[\mathrm{MH}^{+}\right]$calcd. 302.1221; found 302.1225. $[\alpha]_{\mathrm{D}}^{22}=-9.7^{\circ}\left(c=0.248, \mathrm{CHCl}_{3}\right)$.

\section{Kinetic Resolution using Organocatalysis}

Chiral resolution and concurrent formation of an enantioenriched fluorinated alcohol:

tert-Butyl (3S,4S)-3-fluoro-3-(hydroxymethyl)-4-methyl-4-phenylpyrrolidine-1-carboxylate (11b)

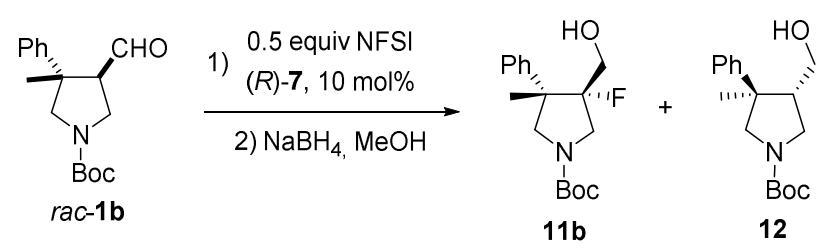

To a $20 \mathrm{~mL}$ microwave vial was added $\mathrm{rac}-\mathbf{1 b}(334 \mathrm{mg}, 1.120 \mathrm{mmol}, 97 \%)$ and $(R)-7$ (67 mg, $0.112 \mathrm{mmol})$ in MTBE (400 $\mu \mathrm{L})$ and the contents were stirred for $5 \mathrm{~min}$ at rt. Subsequently, NFSI (182 $\mathrm{mg}, 0.56 \mathrm{mmol}, 97 \%)$ was poured into the mixture and stirring was continued for $16 \mathrm{~h}$ at rt. $\mathrm{MeOH}(4 \mathrm{~mL})$ was added followed by $\mathrm{NaBH}_{4}(85 \mathrm{mg}, 2.24 \mathrm{mmol}, 2$ equiv) and stirring was continued for $1 \mathrm{~h}$ at rt. Subsequently, half sat. brine $(3 \mathrm{~mL})$ was added followed by EtOAc $(8 \mathrm{~mL})$ and the phases were separated. The aqueous phase was extracted with EtOAc $(2 \times 10 \mathrm{~mL})$ and the organic phases combined, dried over $\mathrm{MgSO}_{4}$, filtered and concentrated in vacuo to provide a crude oil that was purified using silica gel chromatography to provide $11 \mathbf{b}(106 \mathrm{mg}, 0.343$ mmol, $31 \%$ yield, $95 \%$ ee) as a colorless oil. The enantiomeric excess was determined using chiral SFC using a ChiralPak IA column using $10 \%$ modifier $0.1 \%$ diethylamine in EtOH $\left(t_{R}\right.$ major $=2.913 \mathrm{~min} ; t_{R}$ minor $=2.577$ min $)$. The resolved nonfluorinated alcohol 12 (117 mg, $0.402 \mathrm{mmol}, 36 \%$ yield, 79\% ee) was also isolated as a colorless oil. The enantiomeric excess was determined using chiral SFC using a ChiralPak AS-H column using $10 \%$ modifier $0.1 \%$ diethylamine in EtOH $\left(t_{R}\right.$ major $=$ $2.270 \mathrm{~min} ; \mathrm{t}_{\mathrm{R}}$ minor $\left.=1.827 \mathrm{~min}\right)$. Characterization data presented vide supra.

tert-Butyl (3R,4S)-3-fluoro-3-(hydroxymethyl)-4-methyl-4-phenylpyrrolidine-1-carboxylate (13b)

The following approach afforded $\mathbf{1 3 b}$ as a racemate. 


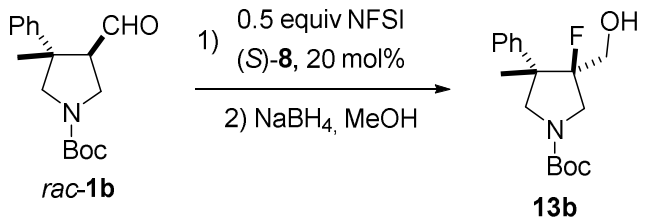

To a flask was added rac-1b (211 mg, $0.715 \mathrm{mmol}, 98 \%)$ and $(S)-8$ in THF/i-PrOH 9:1 (1.5 mL) and then stirred for $5 \mathrm{~min}$ at $\mathrm{rt}$. Subsequently, NFSI (116 mg, $0.357 \mathrm{mmol}, 97 \%$ ) was poured into the mixture and stirring was continued for $16 \mathrm{~h}$ at $40{ }^{\circ} \mathrm{C}$. $\mathrm{MeOH}$ ( $4 \mathrm{~mL}$ ) was added followed by $\mathrm{NaBH}_{4}(54 \mathrm{mg}, 1.43 \mathrm{mmol}, 2$ equiv) and stirring was continued for $1 \mathrm{~h}$ at rt. Subsequently, half sat. brine $(3 \mathrm{~mL})$ was added followed by EtOAc $(8 \mathrm{~mL})$ and the phases were separated. The aqueous phase was extracted with EtOAc $(2 \times 10 \mathrm{~mL})$ and the organic phases combined, dried over $\mathrm{MgSO}_{4}$, filtered and concentrated in vacuo to provide a crude oil that was purified using silica gel chromatography to provide $\mathbf{1 3 b}$ ( $76 \mathrm{mg}, 0.246 \mathrm{mmol}, 34 \%$ yield) as a colorless oil.

\section{Synthesis of Chiral Pyrrolidinyl Carbaldehydes}

With few exceptions, the chiral pyrrolidines were synthesized according to the following procedure using HWE olefination [1], $3+2$ cycloaddition [2], reduction [3] followed by chiral SFC separation, debenzylation, Boc protection [4] and oxidation [5].

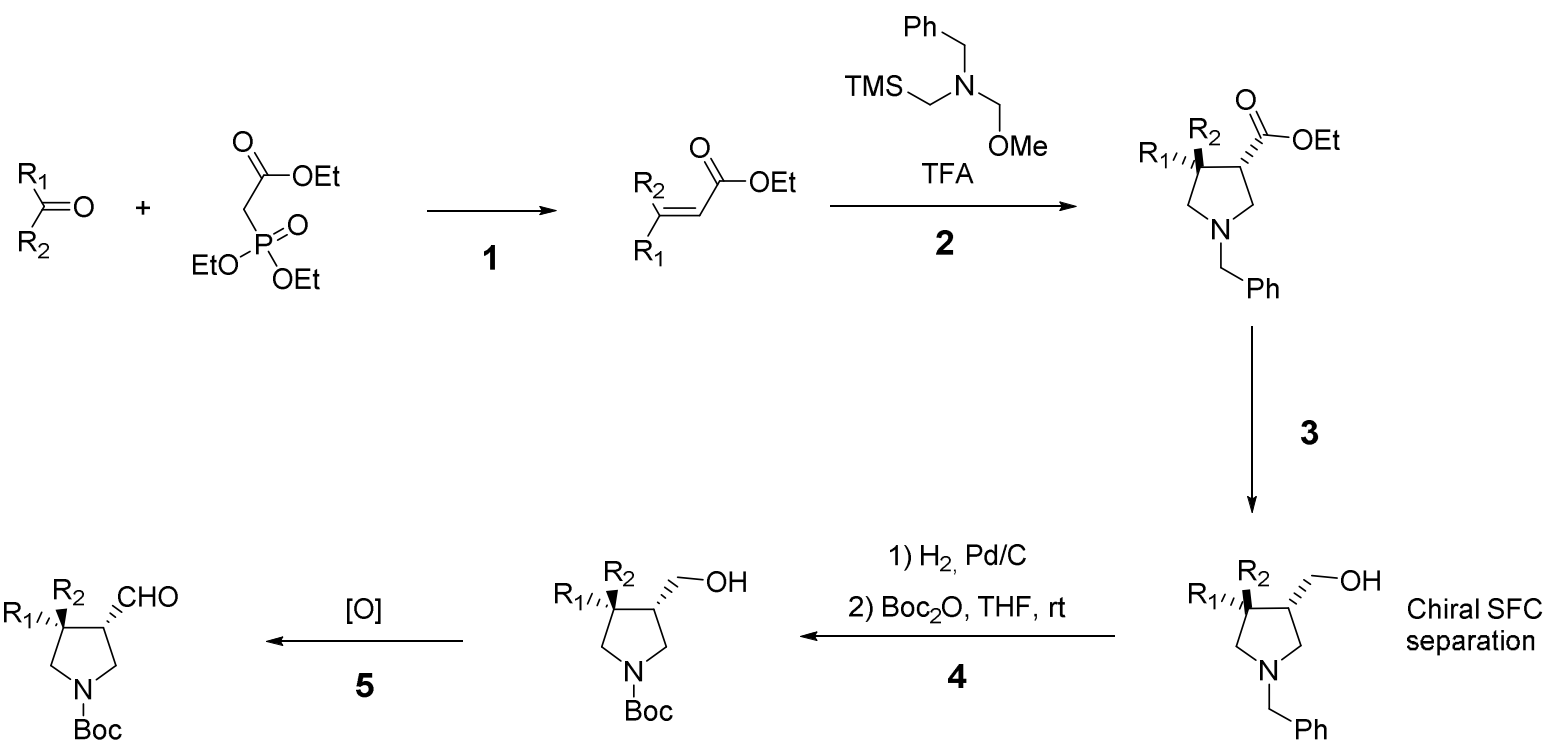

\section{Synthesis of Substrate (1a)}

O (3R,4S)-tert-Butyl 3-formyl-4-phenylpyrrolidine-1-carboxylate (1a) To a solution of oxalyl chloride (1.24 g, 0.85 $\mathrm{Ph}$, $y \mathrm{~mL}, 9.73 \mathrm{mmol})$ in anhydrous $\mathrm{CH}_{2} \mathrm{Cl}_{2}(10 \mathrm{~mL})$ was added DMSO $(1.52 \mathrm{~g}, 1.38 \mathrm{~mL}, 19.5 \mathrm{mmol})$ at $-78^{\circ} \mathrm{C}$. The mixture was stirred for 5 min after which a solution of (3R,4S)-tert-butyl 3-(hydroxymethyl)-4-phenylpyrrolidine-1carboxylate $(1.08 \mathrm{~g}, 3.89 \mathrm{mmol})$ in $\mathrm{CH}_{2} \mathrm{Cl}_{2}(10 \mathrm{~mL})$ was dropwise added and stirring was continued for $30 \mathrm{~min}$. Subsequently, DIPEA $(6.8 \mathrm{~mL}, 39 \mathrm{mmol})$ was dropwise added at $-78^{\circ} \mathrm{C}$ after which the temperature was elevated to $0{ }^{\circ} \mathrm{C}$ and stirring continued for $1 \mathrm{~h} . \mathrm{H}_{2} \mathrm{O}(3 \mathrm{~mL})$ was then added followed by half sat. aq. $\mathrm{NH}_{4} \mathrm{Cl}(10 \mathrm{~mL})$ and the phases were separated. The aqueous phase was extracted with $\mathrm{CH}_{2} \mathrm{Cl}_{2}(2 \times 40 \mathrm{~mL})$, the organic extracts combined, washed with brine and dried over $\mathrm{MgSO}_{4}$. Removal of solvents in vacuo provided a yellow oil that was purified using silica gel chromatography to provide $1 \mathrm{a}\left(726 \mathrm{mg}, 2.64 \mathrm{mmol}, 68 \%\right.$ yield) as a yellow oil. ${ }^{1} \mathrm{H} \mathrm{NMR}\left(600 \mathrm{MHz}, \mathrm{CDCl}_{3}\right) \delta 9.66(\mathrm{br}, 1 \mathrm{H}), 7.37$ $-7.33(\mathrm{~m}, 2 \mathrm{H}), 7.30-7.24(\mathrm{~m}, 3 \mathrm{H}), 3.94-3.56(\mathrm{~m}, 4 \mathrm{H}), 3.52-3.41(\mathrm{~m}, 1 \mathrm{H}), 3.25-3.16(\mathrm{~m}, 1 \mathrm{H}), 1.47(\mathrm{~s}, J=13.3 \mathrm{~Hz}, 9 \mathrm{H}) ;{ }^{13} \mathrm{C}$ NMR $\left(151 \mathrm{MHz}, \mathrm{CDCl}_{3}\right) \delta 199.88,154.11,139.22,138.98,129.02,127.57,127.27,79.95,57.47,56.54,52.60,52.06,45.31$, 45.20, 44.77, 28.46. HRMS-ESI: $m / z \mathrm{C}_{16} \mathrm{H}_{21} \mathrm{NNaO}_{3}\left[\mathrm{MNa}^{+}\right]$calcd. 298.1414; found 298.1422. $[\alpha]_{\mathrm{D}}{ }^{22}=+26^{\circ}\left(c=0.67, \mathrm{CHCl}_{3}\right)$. 


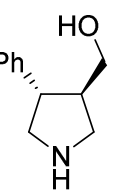

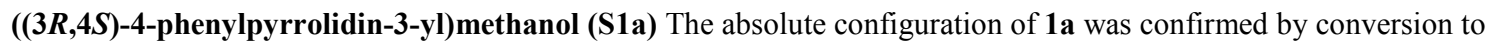
the corresponding $N$-deprotected alcohol $\mathbf{S 1 a}$, which is reported in the literature. ${ }^{1}$ A vial was charged with $(3 S, 4 R)$ tert-butyl 3-(hydroxymethyl)-4-phenylpyrrolidine-1-carboxylate $(75.55 \mathrm{mg}, 0.272 \mathrm{mmol})$ after which $\mathrm{CH}_{2} \mathrm{Cl}_{2}(1 \mathrm{~mL})$ was added followed by the dropwise addition of TFA $(1 \mathrm{~mL})$. This mixture was stirred for 30 min after which toluene $(2 \mathrm{~mL})$ was added and the resulting mixture concentrated in vacuo to provide a yellow substance that was suspended in sat. aq. $\mathrm{NaHCO}_{3}(2 \mathrm{~mL})$ and extracted with EtOAc $(2 \times 8 \mathrm{~mL})$. The organic phases were combined, dried over $\mathrm{MgSO}_{4}$, filtered and concentrated to provide S1a $\left(42 \mathrm{mg}, 0.237 \mathrm{mmol}, 87 \%\right.$ yield) as a yellow oil. $[\alpha]_{\mathrm{D}}{ }^{22}+34.2\left(c 0.33 \mathrm{CHCl}_{3}\right)$. The optical rotation is in accordance with the literature data. ${ }^{1}$

\section{Synthesis of Substrate (1b)}

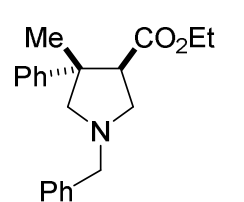

Ethyl trans-1-benzyl-4-methyl-4-phenylpyrrolidine-3-carboxylate (S1b) To a stirred solution of $(E)$-ethyl 3-phenylbut-2-enoate $(2.96 \mathrm{~g}, 15.56 \mathrm{mmol})$ in toluene $(26 \mathrm{~mL})$ was added $N$-benzyl-1-methoxy- $N$ ((trimethylsilyl)methyl)methanamine $(4.43 \mathrm{~g}, 4.78 \mathrm{~mL}, 18.67 \mathrm{mmol})$ at $0{ }^{\circ} \mathrm{C}$ under $\mathrm{N}_{2}$. After $20 \mathrm{~min}$, a solution of TFA $\left(0.120 \mathrm{~mL}, 1.56 \mathrm{mmol}, 1 \mathrm{M}\right.$ in $\left.\mathrm{CH}_{2} \mathrm{Cl}_{2}\right)$ was added slowly at $0{ }^{\circ} \mathrm{C}$. The mixture was stirred for $40 \mathrm{~min}$ at $0{ }^{\circ} \mathrm{C}$ after which the cooling bath was removed and stirring continued for $12 \mathrm{~h}$ at $\mathrm{rt}$. The solvent was removed in vacuo to provide a yellow oil that was purified using silica gel chromatography to provide $\mathbf{S 1 b}$ (2.44 g, $7.54 \mathrm{mmol}$, $49 \%$ yield) as a colorless oil. ${ }^{1} \mathrm{H}$ NMR $\left(600 \mathrm{MHz}, \mathrm{CDCl}_{3}\right) \delta 7.53-7.49(\mathrm{~m}, 2 \mathrm{H}), 7.40-7.37(\mathrm{~m}, 2 \mathrm{H}), 7.34-7.30(\mathrm{~m}, 4 \mathrm{H}), 7.27-$ $7.19(\mathrm{~m}, 2 \mathrm{H}), 4.24-4.11(\mathrm{~m}, 2 \mathrm{H}), 3.72(\mathrm{~d}, J=13.1 \mathrm{~Hz}, 1 \mathrm{H}), 3.65(\mathrm{~d}, J=13.1 \mathrm{~Hz}, 1 \mathrm{H}), 3.33(\mathrm{t}, J=7.7 \mathrm{~Hz}, 1 \mathrm{H}), 3.11-3.05(\mathrm{~m}$, 2H), $2.93(\mathrm{dd}, J=9.3,8.3 \mathrm{~Hz}, 1 \mathrm{H}), 2.63(\mathrm{~d}, J=9.2 \mathrm{~Hz}, 1 \mathrm{H}), 1.39(\mathrm{~s}, 3 \mathrm{H}) ;{ }^{13} \mathrm{C} \mathrm{NMR}\left(151 \mathrm{MHz}, \mathrm{CDCl}_{3}\right) \delta 173.30,149.61,139.41$, $128.73,128.45,128.42,127.12,126.22,68.34,60.60,60.23,56.41,54.55,48.60,24.95,14.54$. LRMS: $\left(\mathrm{UV} \mathrm{t}_{\mathrm{R}}=0.52 \mathrm{~min}\right) \mathrm{m} / \mathrm{z}=$ 323.9. HRMS-ESI: $m / z \mathrm{C}_{21} \mathrm{H}_{26} \mathrm{NO}_{2}\left[\mathrm{MH}^{+}\right]$calcd. 324.1958; found 324.1957.

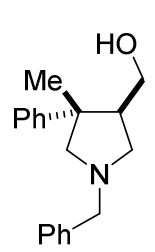

trans-1-Benzyl-4-methyl-4-phenylpyrrolidin-3-yl)methanol (S2b) To a solution of S1b (2.44 g, $7.55 \mathrm{mmol})$ in THF $(53 \mathrm{~mL})$ was slowly added $\mathrm{LiAlH}_{4}\left(8.30 \mathrm{~mL}, 8.3 \mathrm{mmol}, 1 \mathrm{M}\right.$ in THF) at $0{ }^{\circ} \mathrm{C}$. The mixture was stirred at $0{ }^{\circ} \mathrm{C}$ for $45 \mathrm{~min}$ followed by the very slow addition of $\mathrm{H}_{2} \mathrm{O}(3 \mathrm{~mL}), \mathrm{NaOH}(5 \mathrm{M}, 5 \mathrm{~mL})$ then $\mathrm{H}_{2} \mathrm{O}(9 \mathrm{~mL})$. The white suspension was heavily stirred for 30 min followed by filtration through Celite to provide $\mathbf{S 2 b}(2.03 \mathrm{~g}, 7.21 \mathrm{mmol}$, $96 \%$ yield) as a colorless oil. ${ }^{1} \mathrm{H}$ NMR $\left(600 \mathrm{MHz}, \mathrm{CDCl}_{3}\right) \delta 7.43-7.39(\mathrm{~m}, 3 \mathrm{H}), 7.37-7.34(\mathrm{~m}, 2 \mathrm{H}), 7.34-7.28$ $(\mathrm{m}, 3 \mathrm{H}), 7.27-7.23(\mathrm{~m}, 1 \mathrm{H}), 7.20-7.16(\mathrm{~m}, 1 \mathrm{H}), 3.84(\mathrm{dd}, \mathrm{J}=10.6,5.5 \mathrm{~Hz}, 1 \mathrm{H}), 3.72-3.63(\mathrm{~m}, 3 \mathrm{H}), 2.99(\mathrm{~d}, \mathrm{~J}=$ $9.4 \mathrm{~Hz}, 1 \mathrm{H}), 2.92(\mathrm{dd}, \mathrm{J}=9.1,7.7 \mathrm{~Hz}, 1 \mathrm{H}), 2.72(\mathrm{~d}, \mathrm{~J}=9.3 \mathrm{~Hz}, 1 \mathrm{H}), 2.68-2.65(\mathrm{~m}, 1 \mathrm{H}), 2.64-2.59(\mathrm{~m}, 1 \mathrm{H}), 1.95(\mathrm{br}, \mathrm{J}=22.3$ $\mathrm{Hz}, 1 \mathrm{H}), 1.43(\mathrm{~s}, 3 \mathrm{H}) ;{ }^{13} \mathrm{C} \mathrm{NMR}\left(151 \mathrm{MHz}, \mathrm{CDCl}_{3}\right) \delta 150.3,139.3,128.8,128.48,128.47,127.2,126.1,126.0,69.4,63.8,60.5$, 58.2, 50.8, 46.9, 23.6. HRMS-ESI: $m / z$ for $\mathrm{C}_{19} \mathrm{H}_{24} \mathrm{NO}$ [MH ${ }^{+}$] calcd. 282,1852; found 282,1853.

Racemic S2b was separated using chiral SFC on a Lux Cellulose-2 column $\left(\mathrm{t}_{\mathrm{R}}=2.201\right.$ and 2.567 with $20 \%$ modifier $0.1 \%$ diethylamine in $i$-PrOH).

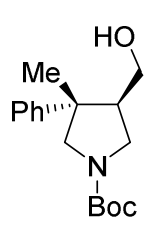

tert-Butyl (3S,4R)-4-(hydroxymethyl)-3-methyl-3-phenylpyrrolidine-1-carboxylate (S3b) To an inert solution of $(3 S, 4 R)-\mathbf{S} 2 \mathbf{b}(786 \mathrm{mg}, 2.79 \mathrm{mmol})$ in EtOH $(38 \mathrm{~mL})$ was added $\mathrm{Pd}(\mathrm{OH})_{2}$ on carbon $(102 \mathrm{mg}, 0.73 \mathrm{mmol}) 20 \%$ wt. The mixture was stirred under $\mathrm{H}_{2}\left(7 \mathrm{bar}, 50^{\circ} \mathrm{C}\right)$ for $6 \mathrm{~h}$ and subsequently passed through a plug of Celite using THF $(2 \times 30 \mathrm{~mL})$. To the filtrate was then added di-tert-butyl dicarbonate $(726 \mathrm{mg}, 3.33 \mathrm{mmol})$ and the mixture was stirred for $14 \mathrm{~h}$ at $\mathrm{rt}$. The solvent was evaporated in vacuo and the resulting residue purified using silica gel chromatography to provide $\mathbf{S 3 b}\left(641 \mathrm{mg}, 2.20 \mathrm{mmol}, 79 \%\right.$ yield) as a dense colorless oil. ${ }^{1} \mathrm{H} \mathrm{NMR}(600 \mathrm{MHz}$, $\left.\mathrm{CDCl}_{3}\right) \delta 7.42$ - $7.38(\mathrm{~m}, 2 \mathrm{H}), 7.37$ - $7.32(\mathrm{~m}, 2 \mathrm{H}), 7.27$ - $7.22(\mathrm{~m}, 1 \mathrm{H}), 3.81$ - $3.71(\mathrm{~m}, 2 \mathrm{H}), 3.65$ - $3.55(\mathrm{~m}, 2 \mathrm{H}), 3.54-3.40(\mathrm{~m}$, $1 \mathrm{H}), 3.36-3.28(\mathrm{~m}, 1 \mathrm{H}), 2.77-2.68(\mathrm{~m}, 1 \mathrm{H}), 1.49-1.45(\mathrm{~m}, 9 \mathrm{H}), 1.36-1.33(\mathrm{~m}, 3 \mathrm{H}) ;{ }^{13} \mathrm{C} \mathrm{NMR}\left(151 \mathrm{MHz}, \mathrm{CDCl}_{3}\right) \delta 154.9$, $144.9,128.8,126.8,126.2,126.1,79.6,62.3,62.2,61.0,60.1,50.5,49.5,49.3,48.8,28.74,28.72$, 19.9. Mixture of conformers. HRMS-ESI: $m / z$ for $\mathrm{C}_{17} \mathrm{H}_{25} \mathrm{NNaO}_{3}\left[\mathrm{MNa}^{+}\right]$calcd. 314,1727; found 314.1732 .

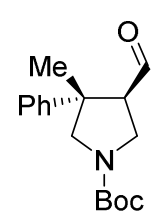

tert-Butyl (3S,4R)-4-formyl-3-methyl-3-phenylpyrrolidine-1-carboxylate (1b) To a solution of oxalyl chloride $(698 \mathrm{mg}, 0.48 \mathrm{~mL}, 5.50 \mathrm{mmol})$ in anhydrous $\mathrm{CH}_{2} \mathrm{Cl}_{2}(10 \mathrm{~mL})$ was added DMSO $(0.78 \mathrm{~mL}, 11 \mathrm{mmol})$ at $-78{ }^{\circ} \mathrm{C}$. The mixture was stirred for $5 \mathrm{~min}$ after which a solution of $\mathbf{S 3 b}(641 \mathrm{mg}, 2.20 \mathrm{mmol})$ in $\mathrm{CH}_{2} \mathrm{Cl}_{2}(6 \mathrm{~mL})$ was added dropwise and further stirred for $30 \mathrm{~min}$. Subsequently, diisopropylethylamine $(2.84 \mathrm{~g}, 3.84 \mathrm{~mL}, 22 \mathrm{mmol})$ was added dropwise at $-78{ }^{\circ} \mathrm{C}$ after which the temperature was elevated to $0{ }^{\circ} \mathrm{C}$ and stirring continued for $1 \mathrm{~h} . \mathrm{H}_{2} \mathrm{O}(3$ $\mathrm{mL})$ was then added followed by half sat. aq. $\mathrm{NH}_{4} \mathrm{Cl}(10 \mathrm{~mL})$ and the phases were separated. The aqueous phase was extracted with $\mathrm{CH}_{2} \mathrm{Cl}_{2}(2 \times 40 \mathrm{~mL})$, the organic extracts combined, washed with brine and dried over $\mathrm{MgSO}_{4}$. Removal of volatiles in vacuo provided a yellow oil that was purified using silica gel chromatography to provide $\mathbf{1 b}(436 \mathrm{mg}, 1.51 \mathrm{mmol}$, 
69\% yield) as a yellow oil. ${ }^{1} \mathrm{H}$ NMR $\left(600 \mathrm{MHz}, \mathrm{CDCl}_{3}\right) \delta 9.74-9.72(\mathrm{~m}, 1 \mathrm{H}), 7.43-7.36(\mathrm{~m}, 4 \mathrm{H}), 7.31-7.27(\mathrm{~m}, 1 \mathrm{H}), 3.87-$ $3.78(\mathrm{~m}, 1 \mathrm{H}), 3.73-3.59(\mathrm{~m}, 2 \mathrm{H}), 3.58-3.51(\mathrm{~m}, 1 \mathrm{H}), 3.41-3.32(\mathrm{~m}, 1 \mathrm{H}), 1.49-1.47(\mathrm{~m}, 9 \mathrm{H}), 1.46-1.44(\mathrm{~m}, 3 \mathrm{H}) ;{ }^{13} \mathrm{C} \mathrm{NMR}$ $\left(151 \mathrm{MHz}, \mathrm{CDCl}_{3}\right) \delta 200.9,154.7,144.1,144.0,129.09,129.07,127.4,126.03,125.96,80.1,60.0,59.44,59.35,58.3,44.6,44.5$, 28.7, 22.1, 22.0 (mixture of conformers). HRMS-ESI: $m / z$ for $\mathrm{C}_{17} \mathrm{H}_{24} \mathrm{NO}_{3}\left[\mathrm{MH}^{+}\right]$calcd. 290.1751 ; found $290.1750 .[\alpha]_{\mathrm{D}}{ }^{22}=-4.0^{\circ}$ $\left(c=1.286, \mathrm{CHCl}_{3}\right)$.

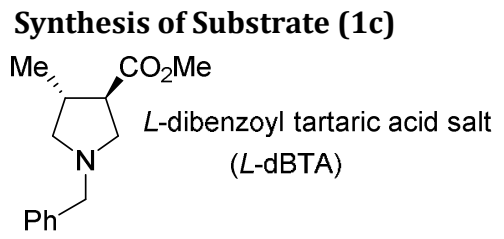

(3R,4R)-methyl 1-benzyl-4-methylpyrrolidine-3-carboxylate $L$-dBTA salt To a solution of trans-1-benzyl-4-methylpyrrolidin-3-yl)methanol (10 g, $42.9 \mathrm{mmol}, 1.0$ equiv) in 4-methylpentan-2-one $(43 \mathrm{~mL}, 1 \mathrm{M})$ was added (-)- $O, O$-dibenzoyl- $L$-tartaric acid (9.98 g, $27.9 \mathrm{mmol}, 0.65$ equiv) and the mixture was heated to $70{ }^{\circ} \mathrm{C}$ and stirring was continued for $1 \mathrm{~h}$. Subsequently, the mixture was cooled to $\mathrm{rt}$ and stirred for $4 \mathrm{~h}$

followed by collection of the precipitate. The precipitated salt was triturated with 4-methylpentan-2-one (10 $\mathrm{mL})$ to afford the enantioenriched product as white solid. To the enantioenriched salt was then added EtOH $(20 \mathrm{~mL})$ and $\mathrm{MTBE}(40 \mathrm{~mL})$ and the resulting suspension was stirred at $70{ }^{\circ} \mathrm{C}$ for $1 \mathrm{~h}$ and allowed to cool to $\mathrm{rt}$ over the course of $6 \mathrm{~h}$. The resulting solid was collected by filtration and washed with MTBE $(20 \mathrm{~mL})$ to afford the single enantiomer $(3 R, 4 R)$-methyl 1-benzyl-4-methylpyrrolidine-3carboxylate $(2 R, 3 R)$-2,3-bis(benzoyloxy)succinate $(4 \mathrm{~g}, 6.76 \mathrm{mmol} 16 \%$ yield) as white solid that was used directly in the next step without further characterization.

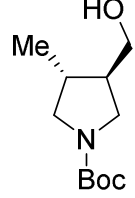

tert-Butyl (3R,4R)-3-(hydroxymethyl)-4-methylpyrrolidine-1-carboxylate (S1c) To a stirred suspension of (3R,4R)-methyl 1-benzyl-4-methylpyrrolidine-3-carboxylate (2R,3R)-2,3-bis(benzoyloxy)succinate (4 g, $6.76 \mathrm{mmol})$ in THF $(100 \mathrm{~mL})$ was added a solution of sat. aq. $\mathrm{Na}_{2} \mathrm{CO}_{3}(80 \mathrm{~mL})$, the mixture was stirred for 30 min after which EtOAc was added and the phases separated. The aqueous phase was washed with EtOAc $(3 \times 125 \mathrm{~mL})$ and the organic phases combined, washed with brine, dried over $\mathrm{MgSO}_{4}$, filterend and concentrated in vacuo to provide a crude oil. The crude oil was dissolved in THF $(80 \mathrm{~mL})$ at $0{ }^{\circ} \mathrm{C}$ after which $\mathrm{LiAlH}_{4}(7.44 \mathrm{~mL}, 7.44 \mathrm{mmol}, 1 \mathrm{M}$ in THF) was added and the mixture stirred for $1 \mathrm{~h}$ after which $\mathrm{Et}_{2} \mathrm{O}(150 \mathrm{~mL})$ was added. Subsequent "fieser work-up"; very slow addition of $\mathrm{H}_{2} \mathrm{O}(134 \mu \mathrm{L}, 7.44 \mathrm{mmol})$ followed by $\mathrm{NaOH}(137 \mu \mathrm{L}, 5 \mathrm{M})$ and $\mathrm{H}_{2} \mathrm{O}(400 \mu \mathrm{L})$ followed by heavy stirring for $1 \mathrm{~h}$. The precipitates were removed by filtration and the resulting clear filtrate was concentrated in vacuo to provide a colorless oil that was rediluted in $\mathrm{EtOH}(40 \mathrm{~mL})$ under inert atmosphere at $\mathrm{rt}$. To this solution was then poured $\mathrm{Pd} / \mathrm{C}(720 \mathrm{mg}, 0.676 \mathrm{mmol}$, $10 \%)$ through a slow stream of $\mathrm{N}_{2}$ after which $\mathrm{NH}_{4} \mathrm{CHOO}(4.26 \mathrm{~g}, 67.6 \mathrm{mmol})$ was added and the mixture was refluxed for $1 \mathrm{~h}$. The solids were filtered off and to the filtrate was added THF $(80 \mathrm{~mL})$ and di-tert-butyl dicarbonate $(1.623 \mathrm{~g}, 7.44 \mathrm{mmol})$ and the resulting solution was stirred overnight at rt. Removal of volatiles in vacuo provided a colorless oil that was purified by silica gel chromatography to provide S1c (1.219 g, $5.66 \mathrm{mmol}, 84 \%$ yield) as a colorless oil. ${ }^{1} \mathrm{H}$ NMR $\left(600 \mathrm{MHz}, \mathrm{CDCl}_{3}\right) \delta 3.75-3.63(\mathrm{~m}$, $1 \mathrm{H}), 3.61-3.45(\mathrm{~m}, 3 \mathrm{H}), 3.18-3.07(\mathrm{~m}, 1 \mathrm{H}), 2.91-2.81(\mathrm{~m}, 1 \mathrm{H}), 2.03-1.84(\mathrm{~m}, 2 \mathrm{H}), 1.41(\mathrm{~s}, 9 \mathrm{H}), 1.04-0.98(\mathrm{~m}, 3 \mathrm{H}) ;{ }^{13} \mathrm{C}$ NMR $\left(151 \mathrm{MHz}, \mathrm{CDCl}_{3}\right) \delta 154.82,154.79,63.3,63.1,53.5,52.9,49.5,49.0,48.2,47.5,35.1,34.4,28$. 7, 17.0. Mixture of conformers. LRMS: $\mathrm{RT}_{\mathrm{TIC}}(0.57 \mathrm{~min}) \mathrm{m} / z=160.0\left[\mathrm{MH}^{+}-t\right.$-Bu]. HRMS-ESI: $m / z$ for $\mathrm{C}_{11} \mathrm{H}_{22} \mathrm{NO}_{3}\left[\mathrm{MH}^{+}\right]$calcd. 216.1594; found 216.1593. $[\alpha]_{\mathrm{D}}^{22}=+40.3^{\circ}\left(c=0.481, \mathrm{CHCl}_{3}\right)$.

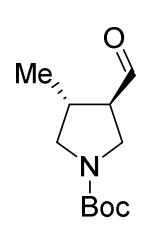

(3R,4R)-tert-Butyl 3-formyl-4-methylpyrrolidine-1-carboxylate (1c) To a solution of S1c (1.219 g, $5.66 \mathrm{mmol})$ in $\mathrm{CH}_{2} \mathrm{Cl}_{2}(33 \mathrm{~mL}, 0.17 \mathrm{M})$ was added Dess-Martin Periodinane $(3.60 \mathrm{~g}, 8.49 \mathrm{mmol})$ at $\mathrm{rt}$. To the stirred suspension was then slowly added $\mathrm{H}_{2} \mathrm{O}(112 \mu \mathrm{L}, 6.23 \mathrm{mmol})$. Stirring was continued for $30 \mathrm{~min}$ followed by the addition of $\mathrm{Et}_{2} \mathrm{O}(150 \mathrm{~mL})$ and the resulting suspension was gently concentrated in vacuo to a few $\mathrm{mL}$ after which $\mathrm{Et}_{2} \mathrm{O}(150$ $\mathrm{mL}$ ) was added. The ethereal solution was washed with a 1:1 mixture of sat. aq. $\mathrm{NaHCO}_{3}$ and $10 \% \mathrm{Na}_{2} \mathrm{~S}_{2} \mathrm{O}_{3}$ until the phases became clear. The aqueous phase was back-extracted with $\mathrm{Et}_{2} \mathrm{O}(100 \mathrm{~mL})$ and the combined ethereal phases were washed with brine, dried over $\mathrm{Na}_{2} \mathrm{SO}_{4}$, filtered, concentrated in vacuo and purified by silica gel chromatography to provide 1c (950 mg, $4.45 \mathrm{mmol}, 79 \%$ yield) as a colorless oil. ${ }^{1} \mathrm{H}$ NMR (600 MHz, $\left.\mathrm{CDCl}_{3}\right) \delta 9.64$ (br, $\left.1 \mathrm{H}\right), 3.66-3.54(\mathrm{~m}, 3 \mathrm{H}), 3.01-$ $2.92(\mathrm{~m}, 1 \mathrm{H}), 2.66-2.57(\mathrm{~m}, 1 \mathrm{H}), 2.54-2.44(\mathrm{~m}, 1 \mathrm{H}), 1.45(\mathrm{~s}, 9 \mathrm{H}), 1.16-1.09(\mathrm{~m}, 3 \mathrm{H}) ;{ }^{13} \mathrm{C} \mathrm{NMR}\left(151 \mathrm{MHz} \mathrm{CDCl}_{3}\right) \delta 200.8$, 200.7, 79.9, 57.9, 57.0, 52.9, 52.5, 45.5, 45.4, 34.8, 34.2, 28.7, 17.2. Mixture of conformers. HRMS-ESI: $m / z$ for $\mathrm{C}_{11} \mathrm{H}_{20} \mathrm{NO}_{3}$ $\left[\mathrm{MH}^{+}\right]$calcd. 214.1438; found 214.1436. $[\alpha]_{\mathrm{D}}^{22}=+14.3\left(c=1.2, \mathrm{CHCl}_{3}\right)$.

\section{Synthesis of Substrate (1d)}




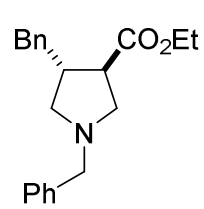

Ethyl trans-1,4-dibenzylpyrrolidine-3-carboxylate (S1d) To a stirred solution of (E)-ethyl 4-phenylbut-2enoate $(5.78 \mathrm{~g}, 23.39 \mathrm{mmol}, 77 \%)$ in toluene $(57 \mathrm{~mL}, 0.41 \mathrm{M})$ was added $N$-benzyl-1-methoxy- $N$ ((trimethylsilyl)methyl)methanamine $(6.94 \mathrm{~g}, 7.48 \mathrm{~mL}, 28.1 \mathrm{mmol}, 96 \%)$ at $0{ }^{\circ} \mathrm{C}$ under $\mathrm{N}_{2}$. After $10 \mathrm{~min}$, a solution of TFA $(180 \mu \mathrm{L}, 2.34 \mathrm{mmol})$ in $\mathrm{CH}_{2} \mathrm{Cl}_{2}(2.3 \mathrm{~mL})$ was added over the course of $10 \mathrm{~min}$ at $0{ }^{\circ} \mathrm{C}$. The mixture was stirred for $75 \mathrm{~min}$ at $0{ }^{\circ} \mathrm{C}$ after which the solvent was removed in vacuo to provide a yellow oil that was purified using silica gel chromatography to provide S1d (7.33 g, $22.66 \mathrm{mmol}, 97 \%$ yield) as a colorless oil. The compound is known and characterized in the literature. ${ }^{2}$

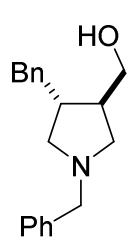

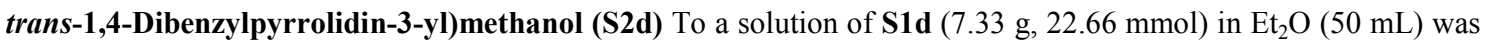
slowly added $\mathrm{LiAlH}_{4}\left(24.93 \mathrm{~mL}, 24.93 \mathrm{mmol}, 1 \mathrm{M}\right.$ in THF) at $0{ }^{\circ} \mathrm{C}$. The mixture was stirred at $0{ }^{\circ} \mathrm{C}$ for $45 \mathrm{~min}$ followed by the addition of $\mathrm{H}_{2} \mathrm{O}(0.8 \mathrm{~mL}), \mathrm{NaOH}(5 \mathrm{M}, 0.8 \mathrm{~mL})$ then $\mathrm{H}_{2} \mathrm{O}(2.4 \mathrm{~mL})$. The white suspension was heavily stirred for $1 \mathrm{~h}$ followed by filtration and the resulting clear solution was concentrated in vacuo at $50{ }^{\circ} \mathrm{C}$ to provide a crystallizing oil that was recrystallized from boiling heptane to provide S2d $(5.43 \mathrm{~g}, 19,30 \mathrm{mmol}, 85 \%$ yield) as a white solid. ${ }^{1} \mathrm{H}$ NMR $\left(600 \mathrm{MHz}, \mathrm{CDCl}_{3}\right) \delta 7.32-7.22(\mathrm{~m}, 7 \mathrm{H}), 7.20-7.16(\mathrm{~m}, 3 \mathrm{H}), 3.60-3.51(\mathrm{~m}, 3 \mathrm{H})$, $3.40(\mathrm{dd}, J=10.0,4.5 \mathrm{~Hz}, 1 \mathrm{H}), 3.15(\mathrm{br}, 1 \mathrm{H}), 3.01-2.97(\mathrm{~m}, 1 \mathrm{H}), 2.74-2.68(\mathrm{~m}, 3 \mathrm{H}), 2.54(\mathrm{dd}, J=9.2,7.1 \mathrm{~Hz}, 1 \mathrm{H}), 2.48-$ $2.41(\mathrm{~m}, 1 \mathrm{H}), 2.05-1.98(\mathrm{~m}, 2 \mathrm{H}) ;{ }^{13} \mathrm{C}$ NMR $\left(151 \mathrm{MHz}, \mathrm{CDCl}_{3}\right) \delta 140.5,138.5,128.8,128.6,128.4,128.3,127.1,126.1,67.3$, 60.6, 60.1, 57.6, 44.9, 42.0, 41.3. LRMS: (UV t $\left.\mathrm{R}_{\mathrm{R}}=0.51 \mathrm{~min}\right) \mathrm{m} / \mathrm{z}=282.1$.

Racemic S2d was separated by chiral SFC using an Amy-C (20mm x 250mm, 5um) column using 20\% modifier with $0.1 \% \mathrm{NH}_{3}$ in $\mathrm{MeOH}\left(\mathrm{t}_{\mathrm{R}}\right.$ peak $1=2.336 \mathrm{~min} ; \mathrm{t}_{\mathrm{R}}$ peak $\left.2=2.553 \mathrm{~min}\right)$. Peak 1 was used in the subsequent reaction.

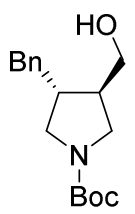

tert-Butyl (3R,4R)-3-benzyl-4-(hydroxymethyl)pyrrolidine-1-carboxylate (S3d) A flask was charged with $(3 R, 4 R)$-S2d $(2.34 \mathrm{~g}, 8.32 \mathrm{mmol})$ in EtOH $(17 \mathrm{~mL}, 0.5 \mathrm{M})$ and the solution was degassed with argon. Subsequently, $\mathrm{Pd}(\mathrm{OH})_{2}$ on carbon $(234 \mathrm{mg}, 1.66 \mathrm{mmol}) 20 \% \mathrm{wt}$ was added and the mixture was placed on a Parr shaker apparatus at $3 \mathrm{bar}$, $\mathrm{rt}$ for $16 \mathrm{~h}$. Subsequently, the reaction mixture was passed through Celite and to the filtrate was added THF $(50 \mathrm{~mL})$ and di-tert-butyl dicarbonate $(1.996 \mathrm{~g}, 9.15 \mathrm{mmol})$ after which the mixture was stirred for $1.5 \mathrm{~h}$ and evaporated to dryness in vacuo. Purification using silca gel chromatography provided S3d $(2.249 \mathrm{~g}, 7.72 \mathrm{mmol}, 93 \%$ yield) as a colorless oil. $[\alpha]_{\mathrm{D}}{ }^{22}=+45^{\circ}(c=1, \mathrm{MeOH})$. The compound is known and characterized in the literature. ${ }^{2}$

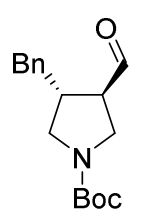

tert-Butyl (3R,4R)-3-benzyl-4-formylpyrrolidine-1-carboxylate (1d) To a solution of S3d (2.24 g, $7.69 \mathrm{mmol})$ in $\mathrm{CH}_{2} \mathrm{Cl}_{2}(70 \mathrm{~mL})$ was added Dess-Martin Periodinane $(4.89 \mathrm{~g}, 11.53 \mathrm{mmol})$ at $0{ }^{\circ} \mathrm{C}$. The mixture was allowed to stirr overnight while allowing to reach rt. $\mathrm{Na}_{2} \mathrm{~S}_{2} \mathrm{O}_{3}(7.29 \mathrm{~g}, 46.1 \mathrm{mmol})$ was added followed by sat. aq. $\mathrm{NaHCO}_{3}(20 \mathrm{~mL})$ and the mixture was stirred for $2 \mathrm{~h}$. The phases were separated and the aqueous phase extracted with EtOAc $(2 \times 80$ $\mathrm{mL}$ ). The organic phases were combined, washed with brine, dried over $\mathrm{MgSO}_{4}$, filtered and concentrated in vacuo to provide a colorless oil that was purified by silica gel chromatography to afford 1d $(2.159 \mathrm{~g}, 7.46 \mathrm{mmol}, 97 \%$ yield $)$ as a colorless oil. ${ }^{1} \mathrm{H}$ NMR $\left(600 \mathrm{MHz}, \mathrm{CDCl}_{3}\right) \delta 9.49(\mathrm{~d}, J=11.9 \mathrm{~Hz}, 2 \mathrm{H}), 7.34-7.27(\mathrm{~m}, 2 \mathrm{H}), 7.25-7.20(\mathrm{~m}, 1 \mathrm{H}), 7.18-7.15$ $(\mathrm{m}, J=7.4 \mathrm{~Hz}, 2 \mathrm{H}), 3.71-3.40(\mathrm{~m}, 3 \mathrm{H}), 3.20-3.10(\mathrm{~m}, 1 \mathrm{H}), 2.82-2.71(\mathrm{~m}, 4 \mathrm{H}), 1.45(\mathrm{~s}, 9 \mathrm{H}) ;{ }^{13} \mathrm{C} \mathrm{NMR}(151 \mathrm{MHz}, \mathrm{CDCl})_{3} \delta$ 200.5, 138.9, 129.1, 128.9, 127.0, 80.0, 55.5, 54.6, 51.1, 50.6, 45.2, 44.9, 41.5, 41.2, 38.7, 28.7. HRMS-ESI: $m / z$ for $\mathrm{C}_{17} \mathrm{H}_{24} \mathrm{NO}_{3}\left[\mathrm{MH}^{+}\right]$calcd. 290.1751; found 290.1745. $[\alpha]_{\mathrm{D}}^{22}=+7.5^{\circ}\left(c=5.44, \mathrm{CHCl}_{3}\right)$.

\section{Synthesis of Substrate (1e)}

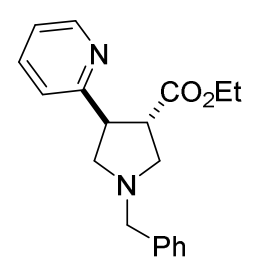

Ethyl trans-1-benzyl-4-(pyridin-2-yl)pyrrolidine-3-carboxylate (S1e) To a stirred solution of (E)-ethyl 3(pyridin-2-yl)acrylate $(3.08 \mathrm{~g}, 17.38 \mathrm{mmol})$ in toluene $(42 \mathrm{~mL}, 0.41 \mathrm{M})$ was added $N$-benzyl-1-methoxy- $N$ ((trimethylsilyl)methyl)methanamine $(4.53 \mathrm{~g}, 4.89 \mathrm{~mL}, 17.38 \mathrm{mmol}, 91 \%)$ at $0{ }^{\circ} \mathrm{C}$ under $\mathrm{N}_{2}$. After $10 \mathrm{~min}$, a solution of TFA $(134 \mu \mathrm{L}, 1.74 \mathrm{mmol})$ in $\mathrm{CH}_{2} \mathrm{Cl}_{2}(3 \mathrm{~mL})$ was added at once and the mixture stirred at $0{ }^{\circ} \mathrm{C}$ while allowing the mixture to reach rt overnight. Subsequently, the volatiles were removed in vacuo to provide a yellow oil that was purified by silica gel chromatography to provide S1e $(4.69 \mathrm{~g}, 15.11 \mathrm{mmol}$, $87 \%$ yield $)$ as a bright yellow oil. ${ }^{1} \mathrm{H}$ NMR $\left(600 \mathrm{MHz}, \mathrm{CDCl}_{3}\right) \delta 8.56(\mathrm{ddd}, \mathrm{J}=4.8,1.8,0.8 \mathrm{~Hz}, 1 \mathrm{H}), 7.58$ $(\mathrm{td}, \mathrm{J}=7.6,1.8 \mathrm{~Hz}, 1 \mathrm{H}), 7.35(\mathrm{dd}, \mathrm{J}=7.9,1.0 \mathrm{~Hz}, 2 \mathrm{H}), 7.32-7.29(\mathrm{~m}, 2 \mathrm{H}), 7.25-7.21(\mathrm{~m}, 2 \mathrm{H}), 7.11(\mathrm{ddd}, \mathrm{J}=7.4,4.9,1.0 \mathrm{~Hz}$, 1H), 4.15 - 4.09 (m, 2H), $3.88-3.83(\mathrm{~m}, 1 \mathrm{H}), 3.69$ (q, J = 13.0 Hz, 2H), 3.49 (ddd, J = 9.0, 7.3, 5.6 Hz, 1H), 3.15 - 3.10 (m, $2 \mathrm{H})$, $2.98(\mathrm{t}, \mathrm{J}=9.3 \mathrm{~Hz}, 1 \mathrm{H}), 2.77(\mathrm{dd}, \mathrm{J}=9.1,8.0 \mathrm{~Hz}, 1 \mathrm{H}), 1.20(\mathrm{t}, \mathrm{J}=7.1 \mathrm{~Hz}, 3 \mathrm{H}) ;{ }^{13} \mathrm{C} \mathrm{NMR}\left(151 \mathrm{MHz}, \mathrm{CDCl}_{3}\right) \delta 174.5,162.1$, 149.6, 139.0, 136.6, 128.9, 128.4, 127.2, 123.2, 121.8, 60.9, 60.9, 60.1, 57.2, 49.3, 49.1, 14.4. LRMS: (UV $\left.\mathrm{t}_{\mathrm{R}}=0.44 \mathrm{~min}\right) \mathrm{m} / z=$ 311.2. HRMS-ESI: $m / z$ for $\mathrm{C}_{19} \mathrm{H}_{23} \mathrm{~N}_{2} \mathrm{O}_{2}\left[\mathrm{MH}^{+}\right]$calcd. 311.1754 ; found 311.1759 . 


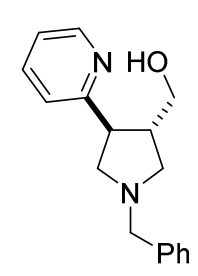

trans-(1-Benzyl-4-(pyridin-2-yl)pyrrolidin-3-yl)methanol (S2e) To a solution of S1e (4.67 g, $15.05 \mathrm{mmol})$ in $\mathrm{Et}_{2} \mathrm{O}(130 \mathrm{~mL})$ was slowly added $\mathrm{LiAlH}_{4}(16.55 \mathrm{~mL}, 16.55 \mathrm{mmol}, 1 \mathrm{M}$ in THF $)$ at $0{ }^{\circ} \mathrm{C}$. The mixture was stirred at $0{ }^{\circ} \mathrm{C}$ for 45 min followed by the very slow addition of $\mathrm{H}_{2} \mathrm{O}(530 \mu \mathrm{L}), \mathrm{NaOH}(530 \mu \mathrm{L}, 5 \mathrm{M})$ then $\mathrm{H}_{2} \mathrm{O}(1.6$ $\mathrm{mL}$ ). The white suspension was heavily stirred for $60 \mathrm{~min}$ followed by filtration and the resulting clear filtrate was concentrated in vacuo to provide a colorless oil that was purified using silica gel chromatography to provide S2e $(2.97 \mathrm{~g}, 11.07 \mathrm{mmol}, 74 \%$ yield $)$ as a colorless dense oil. ${ }^{1} \mathrm{H}$ NMR $\left(600 \mathrm{MHz}, \mathrm{CDCl}_{3}\right) \delta 8.52-8.49(\mathrm{~m}$, $1 \mathrm{H}), 7.61(\mathrm{td}, \mathrm{J}=7.7,1.8 \mathrm{~Hz}, 1 \mathrm{H}), 7.37-7.30(\mathrm{~m}, 4 \mathrm{H}), 7.28-7.23(\mathrm{~m}, 1 \mathrm{H}), 7.16(\mathrm{~d}, \mathrm{~J}=7.9 \mathrm{~Hz}, 1 \mathrm{H}), 7.14-7.11$ (m, 1H), 3.78 - $3.72(\mathrm{~m}, 2 \mathrm{H}), 3.70(\mathrm{~d}, \mathrm{~J}=12.9 \mathrm{~Hz}, 1 \mathrm{H}), 3.64(\mathrm{~d}, \mathrm{~J}=12.9 \mathrm{~Hz}, 1 \mathrm{H}), 3.47$ (dd, J = 14.9, $7.8 \mathrm{~Hz}, 1 \mathrm{H}), 3.30$ - $3.25(\mathrm{~m}$, $1 \mathrm{H}), 2.75(\mathrm{t}, \mathrm{J}=9.0 \mathrm{~Hz}, 1 \mathrm{H}), 2.71(\mathrm{t}, \mathrm{J}=8.8 \mathrm{~Hz}, 1 \mathrm{H}), 2.67(\mathrm{dd}, \mathrm{J}=9.3,4.5 \mathrm{~Hz}, 1 \mathrm{H}), 2.62-2.57(\mathrm{~m}, 1 \mathrm{H}) ;{ }^{13} \mathrm{C} \mathrm{NMR}(151 \mathrm{MHz}$, $\left.\mathrm{CDCl}_{3}\right) \delta 162.8,148.9,139.0,137.0,128.9,128.5,127.3,121.6,121.5,67.1,60.5,59.7,57.8,50.3,46.6$. LC MS: $\left(\mathrm{UV} \mathrm{t}_{\mathrm{R}}=0.30\right.$ $\min ) \mathrm{m} / z=269.2$. HRMS-ESI: $m / z$ for $\mathrm{C}_{17} \mathrm{H}_{21} \mathrm{~N}_{2} \mathrm{O}\left[\mathrm{MH}^{+}\right]$calcd. 269.1648; found 269.1649.

Racemic S2e was separated using chiral SFC on a ChiralPak AD $(300 \times 50 \mathrm{~mm}$ I.D., $10 \mu \mathrm{m})$ column using $30 \%$ modifier with $0.1 \% \mathrm{NH}_{3} \mathrm{H}_{2} \mathrm{O}$ in EtOH. $\left(t_{\mathrm{R}}\right.$ peak $1=2.30 \mathrm{~min} ; \mathrm{t}_{\mathrm{R}}$ peak $\left.2=2.64 \mathrm{~min}\right)$. Peak 2 was used in the subsequent reaction.

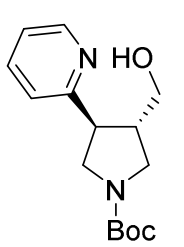

(3R,4R)-tert-Butyl 3-(hydroxymethyl)-4-(pyridin-2-yl)pyrrolidine-1-carboxylate (S3e) To an inert and degassed solution of $(3 R, 4 R)-\mathbf{S 2 e}(1.29 \mathrm{~g}, 4.81 \mathrm{mmol})$ in $\mathrm{MeOH}(48 \mathrm{~mL}, 0.1 \mathrm{M})$ was added $\mathrm{Pd} / \mathrm{C}(512 \mathrm{mg}, 0.481$ mmol, $10 \%$ ) followed by $\mathrm{NH}_{4} \mathrm{CHOO}(3.0 \mathrm{~g}, 48 \mathrm{mmol})$. The mixture was refluxed for $1 \mathrm{~h}$ and subsequently allowed to reach $\mathrm{rt}$ followed by filtration of the catalyst by Celite. To the resulting filtrate was then added di-tertbutyl dicarbonate $(1.154 \mathrm{~g}, 5.29 \mathrm{mmol})$ and stirring was continued for $2 \mathrm{~h}$ at rt. Evaporation of volatiles in vacuo provided a crude solid that was suspended in $\mathrm{CH}_{2} \mathrm{Cl}_{2}$ and filtered, the resulting filtrate was concentrated and subjected to silica gel chromatography to provide S3e $\left(0.85 \mathrm{~g}, 3.1 \mathrm{mmol}, 64 \%\right.$ yield) as a dense colorless oil. ${ }^{1} \mathrm{H} \mathrm{NMR}(600 \mathrm{MHz}$, $\left.\mathrm{CDCl}_{3}\right) \delta 8.55-8.49(\mathrm{~m}, 1 \mathrm{H}), 7.72-7.66(\mathrm{~m}, 1 \mathrm{H}), 7.23-7.16(\mathrm{~m}, 2 \mathrm{H}), 4.16-3.98(\mathrm{~m}, 1 \mathrm{H}), 3.77-3.64(\mathrm{~m}, 3 \mathrm{H}), 3.52(\mathrm{t}, \mathrm{J}=10.5$ $\mathrm{Hz}, 1 \mathrm{H}), 3.46-3.36(\mathrm{~m}, 1 \mathrm{H}), 3.21-3.10(\mathrm{~m}, 1 \mathrm{H}), 2.75-2.67(\mathrm{~m}, 1 \mathrm{H}), 1.47(\mathrm{~s}, 9 \mathrm{H}) ;{ }^{13} \mathrm{C} \mathrm{NMR}\left(151 \mathrm{MHz}, \mathrm{CDCl}_{3}\right) \delta 159.7,159.6$, 154.6, 154.5, 148.8, 148.5, 137.7, 137.4, 122.6, 122.5, 122.4, 79.8, 64.3, 64.1, 51.7, 51.3, 50.3, 49.9, 49.0, 48.6, 46.0, $45.3,28.7$. Mixture of conformers. HRMS-ESI: $m / z$ for $\mathrm{C}_{15} \mathrm{H}_{23} \mathrm{~N}_{2} \mathrm{O}_{3}\left[\mathrm{MH}^{+}\right]$calcd. 279.1703; found 279.1704. $[\alpha]_{\mathrm{D}}^{22}=+8.5^{\circ}(c=0.176$, $\left.\mathrm{CHCl}_{3}\right)$.

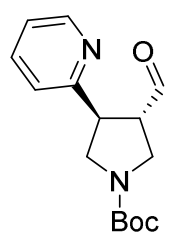

(3R,4R)-tert-Butyl 3-formyl-4-(pyridin-2-yl)pyrrolidine-1-carboxylate (1e) Synthesized using $\mathrm{H}_{2} \mathrm{O}$-accelerated DMP oxidation. ${ }^{3}$ To a solution of $\mathbf{S 3 e}(0.85 \mathrm{~g}, 3.1 \mathrm{mmol})$ in $\mathrm{CH}_{2} \mathrm{Cl}_{2}(18 \mathrm{~mL}, 0.17 \mathrm{M})$ was added Dess-Martin Periodinane $(1.94 \mathrm{~g}, 4.6 \mathrm{mmol})$ at $\mathrm{rt}$. To the stirred suspension was then slowly added water $(61 \mu \mathrm{L}, 3.36 \mathrm{mmol})$. Stirring was continued for 30 min followed by the addition of $\mathrm{Et}_{2} \mathrm{O}(150 \mathrm{~mL})$ and the resulting suspension was gently concentrated in vacuo to a few $\mathrm{mL}$ after which $\mathrm{Et}_{2} \mathrm{O}(150 \mathrm{~mL})$ was added. The ethereal solution was washed with a 1:1 mixture of sat. aq. $\mathrm{NaHCO}_{3}$ and $10 \% \mathrm{Na}_{2} \mathrm{~S}_{2} \mathrm{O}_{3}$ until the phases became clear. The aqueous phase was back-extracted with $\mathrm{Et}_{2} \mathrm{O}(100 \mathrm{~mL})$ and the combined ethereal phases were washed with brine, dried over $\mathrm{Na}_{2} \mathrm{SO}_{4}$, filtered, concentrated in vacuo and purified by silica gel chromatography to provide $1 \mathrm{e}(0.65 \mathrm{~g}, 2.35 \mathrm{mmol}, 77 \% \mathrm{yield})$ as a colorless oil. ${ }^{1} \mathrm{H}$ NMR $\left(600 \mathrm{MHz}, \mathrm{CDCl}_{3}\right) \delta 9.77(\mathrm{~d}, \mathrm{~J}=10.9 \mathrm{~Hz}, 1 \mathrm{H}), 8.56(\mathrm{~d}, \mathrm{~J}=4.3 \mathrm{~Hz}, 1 \mathrm{H}), 7.64(\mathrm{t}, \mathrm{J}=7.2 \mathrm{~Hz}, 1 \mathrm{H}), 7.21-$ $7.17(\mathrm{~m}, 2 \mathrm{H}), 3.96-3.55(\mathrm{~m}, 6 \mathrm{H}), 1.49-1.43(\mathrm{~m}, 9 \mathrm{H}) ;{ }^{13} \mathrm{C} \mathrm{NMR}\left(151 \mathrm{MHz}, \mathrm{CDCl}_{3}\right) \delta 200.5,200.4,158.6,154.4,150.0,149.9$, 137.0, 122.9, 122.8, 122.6, 80.0, 55.7, 55.1, 51.6, 51.2, 46.9, 46.4, 45.6, 28.7. Mixture of conformers. HRMS-ESI: $m / z$ for $\mathrm{C}_{15} \mathrm{H}_{21} \mathrm{~N}_{2} \mathrm{O}_{3}\left[\mathrm{MH}^{+}\right]$calcd. 277.1547; found 277.1549. $[\alpha]_{\mathrm{D}}^{22}=-12.9^{\circ}\left(c=0.94, \mathrm{CHCl}_{3}\right)$.

\section{Synthesis of Substrate (1f)}

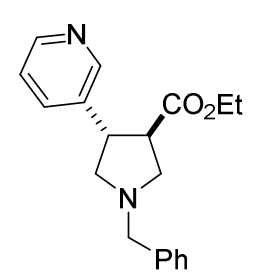

Ethyl trans-1-benzyl-4-(pyridin-3-yl)pyrrolidine-3-carboxylate (S1f) To a stirred solution of (E)-ethyl 3(pyridin-3-yl)acrylate $(3.43 \mathrm{~g}, 19.33 \mathrm{mmol})$ in toluene $(47 \mathrm{~mL}, 0.41 \mathrm{M})$ was added $N$-benzyl-1-methoxy- $N$ ((trimethylsilyl)methyl)methanamine $(5.04 \mathrm{~g}, 5.43 \mathrm{~mL}, 19.33 \mathrm{mmol}, 91 \%)$ at $0{ }^{\circ} \mathrm{C}$ under $\mathrm{N}_{2}$. After $10 \mathrm{~min}$, a solution of TFA $(149 \mu \mathrm{L}, 1.93 \mathrm{mmol})$ in $\mathrm{CH}_{2} \mathrm{Cl}_{2}(4 \mathrm{~mL})$ was added over the course of 5 min and stirring was continued at $0{ }^{\circ} \mathrm{C}$ while allowing the mixture to reach $\mathrm{rt}$ over 3 days. Subsequently, the solvent was removed in vacuo to provide a brown oil that was purified using silca gel chromatography to provide S1f (1.86 g, $5.99 \mathrm{mmol}, 31 \%$ yield) as a yellow oil. ${ }^{1} \mathrm{H}$ NMR $\left(600 \mathrm{MHz}, \mathrm{CDCl}_{3}\right) \delta 8.58(\mathrm{~d}, \mathrm{~J}=2.2 \mathrm{~Hz}, 1 \mathrm{H}), 8.46$ $(\mathrm{dd}, \mathrm{J}=4.7,1.3 \mathrm{~Hz}, 1 \mathrm{H}), 7.69(\mathrm{~d}, \mathrm{~J}=7.9 \mathrm{~Hz}, 1 \mathrm{H}), 7.38-7.35(\mathrm{~m}, 2 \mathrm{H}), 7.34-7.31(\mathrm{~m}, 2 \mathrm{H}), 7.28-7.25(\mathrm{~m}, 1 \mathrm{H}), 7.25-7.22(\mathrm{~m}$, $1 \mathrm{H}), 4.18-4.09(\mathrm{~m}, 2 \mathrm{H}), 3.71(\mathrm{~d}, \mathrm{~J}=13.0 \mathrm{~Hz}, 1 \mathrm{H}), 3.68-3.63(\mathrm{~m}, 2 \mathrm{H}), 3.14(\mathrm{t}, \mathrm{J}=8.9 \mathrm{~Hz}, 1 \mathrm{H}), 3.04(\mathrm{dd}, \mathrm{J}=14.9,7.5 \mathrm{~Hz}, 1 \mathrm{H})$, $2.96(\mathrm{t}, \mathrm{J}=8.8 \mathrm{~Hz}, 1 \mathrm{H}), 2.80(\mathrm{ddd}, \mathrm{J}=12.3,9.3,6.5 \mathrm{~Hz}, 2 \mathrm{H}), 1.22(\mathrm{t}, \mathrm{J}=7.1 \mathrm{~Hz}, 3 \mathrm{H}) ;{ }^{13} \mathrm{C} \mathrm{NMR}\left(151 \mathrm{MHz} \mathrm{CDCl}_{3}\right) \delta 173.7$, 
$149.3,148.1,140.1,138.7,134.9,128.6,128.4,127.2,123.6,61.3,61.0,59.8,57.3,51.8,44.4,14.2$. HRMS-ESI: $m / z$ for $\mathrm{C}_{19} \mathrm{H}_{23} \mathrm{~N}_{2} \mathrm{O}_{2}\left[\mathrm{MH}^{+}\right]$calcd. 311.1754; found 311.1759.

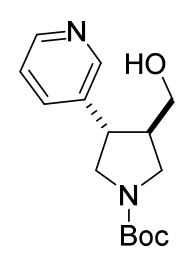

tert-Butyl trans-3-(hydroxymethyl)-4-(pyridin-3-yl)pyrrolidine-1-carboxylate (S2f) To a solution of S1f (1.86 $\mathrm{g}, 5.99 \mathrm{mmol})$ in THF $(30 \mathrm{~mL}, 0.2 \mathrm{M})$ at $0{ }^{\circ} \mathrm{C}, \mathrm{LiAlH}_{4}(6.59 \mathrm{~mL}, 6.59 \mathrm{mmol}, 1 \mathrm{M})$ was added and the mixture stirred for $30 \mathrm{~min}$ after which the mixture was diluted with $\mathrm{Et}_{2} \mathrm{O}(100 \mathrm{~mL})$. Subsequent "fieser work-up"; very slow addition of $\mathrm{H}_{2} \mathrm{O}(0.204 \mathrm{~mL})$ followed by $\mathrm{NaOH}(0.204 \mathrm{~mL}, 5 \mathrm{M})$ and $\mathrm{H}_{2} \mathrm{O}(0.612 \mathrm{~mL})$ followed by heavy stirring for $30 \mathrm{~min}$, filtration of precipitates, concentration of the filtrate in vacuo provided a colorless oil that was rediluted in $\mathrm{MeOH}(30 \mathrm{~mL})$ and degassed with argon for $15 \mathrm{~min}$. To the degassed solution was subsequently added $\mathrm{Pd} / \mathrm{C}$ (638 mg, $0.60 \mathrm{mmol}, 10 \%)$ and $\mathrm{NH}_{4} \mathrm{CHOO}(3.78 \mathrm{~g}, 59.9 \mathrm{mmol}$ ) after which the mixture was refluxed for $35 \mathrm{~min}$. The heating was discontinued and the mixture cooled to $\mathrm{rt}$ and passed through a plug of Celite. To the clear filtered solution was added THF $(35 \mathrm{~mL})$ and di-tert-butyl dicarbonate $(1.37 \mathrm{~g}, 6.29 \mathrm{mmol})$ and the mixture was stirred for $2 \mathrm{~h}$ and concentrated in vacuo to yield a crude oil that was purified using silica gel chromatography to provide $\mathbf{S 2 f}$ (1.23 g, $4.42 \mathrm{mmol}$, $74 \%$ yield $)$ as a colorless oil. ${ }^{1} \mathrm{H}$ NMR $\left(600 \mathrm{MHz}, \mathrm{CDCl}_{3}\right) \delta 8.51-8.46(\mathrm{~m}, 2 \mathrm{H}), 7.61-7.58(\mathrm{~m}, 1 \mathrm{H}), 7.28(\mathrm{dd}, \mathrm{J}=7.9,4.8 \mathrm{~Hz}$, 1H), 3.91 - $3.72(\mathrm{~m}, 2 \mathrm{H}), 3.69-3.64(\mathrm{~m}, 1 \mathrm{H}), 3.55(\mathrm{dd}, \mathrm{J}=16.4,8.7 \mathrm{~Hz}, 1 \mathrm{H}), 3.43-3.31(\mathrm{~m}, 2 \mathrm{H}), 3.28$ - $3.16(\mathrm{~m}, 1 \mathrm{H}), 2.51$ $2.44(\mathrm{~m}, 1 \mathrm{H}), 1.49-1.44(\mathrm{~m}, 9 \mathrm{H}) ;{ }^{13} \mathrm{C}$ NMR $\left(151 \mathrm{MHz}, \mathrm{CDCl}_{3}\right) \delta 154.5,149.6,148.6,136.2,135.1,124.1,124.0,79.8,62.1$, 62.0, 60.6, 53.2, 52.6, 49.2, 48.7, 48.5, 47.5, 43.9, 43.2, 28.7, 21.3, 14.4. Mixture of confomers and a minor amount of EtOAc. LRMS: $\left(\mathrm{UV} \mathrm{t}_{\mathrm{R}}=0.34 \mathrm{~min}\right) \mathrm{m} / \mathrm{z}=279.1$. HRMS-ESI: $\mathrm{m} / z$ for $\mathrm{C}_{15} \mathrm{H}_{23} \mathrm{~N}_{2} \mathrm{O}_{3}\left[\mathrm{MH}^{+}\right]$calcd. 279.1703; found 279.1709.

Racemic S2f was separated using chiral SFC on a Lux Cellulose- 1 column with $20 \%$ modifier containing $0.1 \%$ diethylamine in EtOH. $\left(t_{\mathrm{R}}\right.$ peak $1=2.740 \mathrm{~min} ; \mathrm{t}_{\mathrm{R}}$ peak $\left.2=3.286 \mathrm{~min}\right)$. Peak 2 was used in the subsequent reaction.

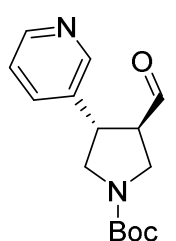

(3R,4S)-tert-Butyl 3-formyl-4-(pyridin-3-yl)pyrrolidine-1-carboxylate (1f) To a solution of (3R,4S)-S2f $(525$ $\mathrm{mg}, 1.886 \mathrm{mmol})$ in $\mathrm{CH}_{2} \mathrm{Cl}_{2}(11 \mathrm{~mL}, 0.17 \mathrm{M})$ was added Dess-Martin Periodinane $(1.20 \mathrm{~g}, 2.83 \mathrm{mmol})$ at rt. To the stirred suspension was then slowly added $\mathrm{H}_{2} \mathrm{O}(37 \mu \mathrm{L})$. Stirring was continued for 50 min followed by the addition of $\mathrm{Et}_{2} \mathrm{O}(150 \mathrm{~mL})$ and the resulting suspension was gently concentrated in vacuo to a few $\mathrm{mL}$ after which $\mathrm{Et}_{2} \mathrm{O}(150 \mathrm{~mL})$ was added. The ethereal solution was washed with a $1: 1$ mixture of sat. aq. $\mathrm{NaHCO}_{3}$ and $10 \%$

Boc $\mathrm{Na}_{2} \mathrm{~S}_{2} \mathrm{O}_{3}$ until the phases became clear. The aqueous phase was back-extracted with $\mathrm{Et}_{2} \mathrm{O}(2 \times 100 \mathrm{~mL})$ and the combined ethereal phases were dried over $\mathrm{Na}_{2} \mathrm{SO}_{4}$, filtered and concentrated in vacuo to provide a crude oil that was purified by silica gel chromatography to provide $1 \mathrm{f}\left(361 \mathrm{mg}, 1.305 \mathrm{mmol}, 69 \%\right.$ yield) as a colorless oil. ${ }^{1} \mathrm{H} \mathrm{NMR}\left(600 \mathrm{MHz} \mathrm{CDCl}_{3}\right) \delta 9.71-$ $9.68(\mathrm{~m}, 1 \mathrm{H}), 8.56-8.54(\mathrm{~m}, 1 \mathrm{H}), 8.54-8.51(\mathrm{~m}, 1 \mathrm{H}), 7.62$ - $7.58(\mathrm{~m}, 1 \mathrm{H}), 7.33-7.28(\mathrm{~m}, 1 \mathrm{H}), 3.94-3.65(\mathrm{~m}, 4 \mathrm{H}), 3.53-3.43$ $(\mathrm{m}, 1 \mathrm{H}), 3.26-3.17(\mathrm{~m}, 1 \mathrm{H}), 1.50-1.45(\mathrm{~m}, 9 \mathrm{H}) ;{ }^{13} \mathrm{C} \mathrm{NMR}\left(151 \mathrm{MHz}, \mathrm{CDCl}_{3}\right) \delta 199.12,199.06,154.0,149.1,149.0,135.1$, 135.0, 134.6, 123.8, 80.2, 57.2, 56.2, 52.2, 51.7, 45.3, 45.2, 42.3, 41.8, 28.4. Mixture of conformers.

\section{Synthesis of Substrate (1g)}

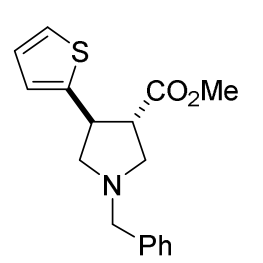

Methyl trans-1-benzyl-4-(thiophen-2-yl)pyrrolidine-3-carboxylate (S1g) To a stirred solution of $(E)$ methyl 3-(thiophen-2-yl)acrylate $(1.56 \mathrm{~g}, 9.27 \mathrm{mmol})$ in toluene $(23 \mathrm{~mL}, 0.41 \mathrm{M})$ was added $N$-benzyl-1methoxy- $N$-((trimethylsilyl)methyl)methanamine $(2.75 \mathrm{~g}, 2.97 \mathrm{~mL}, 11.13 \mathrm{mmol}, 96 \%)$ at $0{ }^{\circ} \mathrm{C}$ under $\mathrm{N}_{2}$. After $10 \mathrm{~min}$, a solution of TFA $(71 \mu \mathrm{L}, 0.93 \mathrm{mmol})$ in $\mathrm{CH}_{2} \mathrm{Cl}_{2}(2 \mathrm{~mL})$ was added over the course of $10 \mathrm{~min}$ at $0{ }^{\circ} \mathrm{C}$. The mixture was stirred for $1 \mathrm{~h}$ at $0{ }^{\circ} \mathrm{C}$ after which the solvent was removed in vacuo to provide a yellow oil that was purified using silica gel chromatography to afford $\mathbf{S 1 g}(2.1 \mathrm{~g}, 6.97 \mathrm{mmol}, 75 \%$ yield $)$ as a colorless oil. ${ }^{1} \mathrm{H}$ NMR $\left(600 \mathrm{MHz}, \mathrm{CDCl}_{3}\right) \delta 7.39$ - $7.30(\mathrm{~m}, 4 \mathrm{H}), 7.27-7.24(\mathrm{~m}, 1 \mathrm{H}), 7.15(\mathrm{dd}, \mathrm{J}=4.9,1.4$ $\mathrm{Hz}, 1 \mathrm{H}), 6.92-6.88(\mathrm{~m}, 2 \mathrm{H}), 4.01-3.97(\mathrm{~m}, 1 \mathrm{H}), 3.73-3.64(\mathrm{~m}, 5 \mathrm{H}), 3.12(\mathrm{dt}, \mathrm{J}=8.8,6.3 \mathrm{~Hz}, 1 \mathrm{H}), 3.07-3.00(\mathrm{~m}, 2 \mathrm{H}), 2.88$ $(\mathrm{dd}, \mathrm{J}=9.4,6.3 \mathrm{~Hz}, 1 \mathrm{H}), 2.74(\mathrm{dd}, \mathrm{J}=9.2,6.4 \mathrm{~Hz}, 1 \mathrm{H}) ;{ }^{13} \mathrm{C} \mathrm{NMR}\left(151 \mathrm{MHz}, \mathrm{CDCl}_{3}\right) \delta 174.4,147.5,138.7,128.7,128.3,127.1$, $126.6,124.0,123.8,61.9,59.7,56.8,52.1,52.0,42.4$.

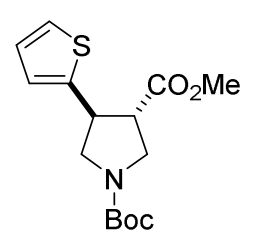

trans-1-tert-Butyl 3-methyl 4-(thiophen-2-yl)pyrrolidine-1,3-dicarboxylate (S2g) To a solution of S1g $(2.455 \mathrm{~g}, 8.14 \mathrm{mmol})$ in toluene $(80 \mathrm{~mL})$ was added 1-chloroethyl carbonochloridate $(2.33 \mathrm{~g}, 1.76 \mathrm{~mL}$, $16.29 \mathrm{mmol}$ ) at $\mathrm{rt}$ and the mixture was refluxed for $3 \mathrm{~h}$ after which an additional equivalent of 1-chloroethyl carbonochloridate was added. The reflux was continued for $1 \mathrm{~h}$ after which the mixture was allowed to cool to rt. EtOAc $(150 \mathrm{~mL})$ was added and the organics were washed with sat. aq. $\mathrm{NaHCO}_{3}(40 \mathrm{~mL})$ and brine, dried over $\mathrm{MgSO}_{4}$ and concentrated in vacuo. The resulting residue was dissolved in $\mathrm{MeOH}(55 \mathrm{~mL})$ and refluxed for $2 \mathrm{~h}$, allowed to cool to $\mathrm{rt}$ followed by removal of the volatiles in vacuo. Subsequently, $\mathrm{CH}_{2} \mathrm{Cl}_{2}(60 \mathrm{~mL})$ was added followed by $\mathrm{Et}_{3} \mathrm{~N}(1.14 \mathrm{~mL}, 8.14 \mathrm{mmol})$ and di-tert-butyl dicarbonate $(2.13 \mathrm{~g}, 9.77 \mathrm{mmol})$ at rt. The reaction mixture was stirred 
for $2 \mathrm{~h}$ after which the volatiles were removed in vacuo and the crude product purified by silica gel chromatography to provide S2g (1.615 g, $5.19 \mathrm{mmol}, 64 \%$ yield) as a colorless oil. ${ }^{1} \mathrm{H}$ NMR $\left(600 \mathrm{MHz}, \mathrm{CDCl}_{3}\right) \delta 7.20-7.18(\mathrm{~m}, 1 \mathrm{H}), 6.95-6.93(\mathrm{~m}, 1 \mathrm{H})$, $6.91-6.89(\mathrm{~m}, 1 \mathrm{H}), 3.99-3.79(\mathrm{~m}, 3 \mathrm{H}), 3.69(\mathrm{~s}, 3 \mathrm{H}), 3.61-3.53(\mathrm{~m}, 1 \mathrm{H}), 3.51-3.40(\mathrm{~m}, 1 \mathrm{H}), 3.19-3.11(\mathrm{~m}, 1 \mathrm{H}), 1.48-1.44$ $(\mathrm{m}, 9 \mathrm{H}) ;{ }^{13} \mathrm{C} \mathrm{NMR}\left(151 \mathrm{MHz}, \mathrm{CDCl}_{3}\right) \delta 172.62,172.53,154.12,142.71,142.55,127.11,124.86,124.83,124.30,80.06,53.12$, $52.54,52.46,51.73,50.76,49.02,48.69,43.12,42.42,28.64$. Mixture of conformers. LRMS: $\left(\mathrm{UV} \mathrm{t}_{\mathrm{R}}=0.81 \mathrm{~min}\right) \mathrm{m} / \mathrm{z}=256.0$.

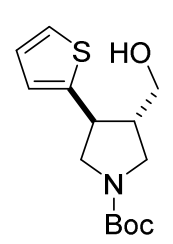

tert-Butyl trans-3-(hydroxymethyl)-4-(thiophen-2-yl)pyrrolidine-1-carboxylate (S3g) To a solution of S2g $(1.615 \mathrm{~g}, 5.19 \mathrm{mmol})$ in THF $(26 \mathrm{~mL}, 0.2 \mathrm{M})$ was slowly added $\mathrm{LiAlH}_{4}(5.70 \mathrm{~mL}, 5.70 \mathrm{mmol}, 1 \mathrm{M}$ in $\mathrm{THF})$ at $0{ }^{\circ} \mathrm{C}$ and the mixture was stirred for $30 \mathrm{~min}$ after which $\mathrm{Et}_{2} \mathrm{O}(100 \mathrm{~mL})$ was added. Subsequent "fieser work-up"; very slow addition of $\mathrm{H}_{2} \mathrm{O}(177 \mu \mathrm{L})$ followed by $\mathrm{NaOH}(177 \mu \mathrm{L}, 5 \mathrm{M})$ and $\mathrm{H}_{2} \mathrm{O}(531 \mu \mathrm{L})$ followed by heavy stirring for $30 \mathrm{~min}$, filtration of precipitates and concentration of the filtrate in vacuo to provide $\mathbf{S 3 g}(1.465 \mathrm{~g}, 5.17 \mathrm{mmol}$, $100 \%$ yield) as a colorless oil . ${ }^{1} \mathrm{H}$ NMR $\left(600 \mathrm{MHz}, \mathrm{CDCl}_{3}\right) \delta 7.20-7.18(\mathrm{~m}, 1 \mathrm{H}), 6.96-6.93(\mathrm{~m}, 1 \mathrm{H}), 6.91-$ $6.89(\mathrm{~m}, 1 \mathrm{H}), 3.95-3.83(\mathrm{~m}, 1 \mathrm{H}), 3.78-3.75(\mathrm{~m}, 2 \mathrm{H}), 3.63-3.58(\mathrm{~m}, 1 \mathrm{H}), 3.54-3.27(\mathrm{~m}, 3 \mathrm{H}), 2.49-2.42(\mathrm{~m}, 1 \mathrm{H}), 1.78(\mathrm{br}$, $1 \mathrm{H}), 1.48-1.44(\mathrm{~m}, 9 \mathrm{H}) ;{ }^{13} \mathrm{C} \mathrm{NMR}\left(151 \mathrm{MHz}, \mathrm{CDCl}_{3}\right) \delta 154.54,143.85,143.78,127.13,124.86,124.04,79.70,62.60,62.37$, $54.17,53.53,49.45,49.21,48.62,48.58,41.69,41.03,28.70$.

Racemic S3g was separated by chiral SFC on a Lux Cellulose- 2 column using $40 \%$ modifier with $0.1 \%$ diethylamine in EtOH $\left(t_{R}\right.$ peak $1=1.892 \mathrm{~min} ; \mathrm{t}_{\mathrm{R}}$ peak $2=2.229$ min with $20 \%$ modifier). Peak 1 was used in the subsequent reaction.

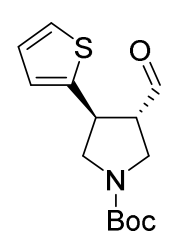

(3S,4S)-tert-Butyl 3-formyl-4-(thiophen-2-yl)pyrrolidine-1-carboxylate (1g) To a solution of (3R,4R)- $\mathbf{S 3 g}(442$ $\mathrm{mg}, 1.560 \mathrm{mmol})$ in $\mathrm{CH}_{2} \mathrm{Cl}_{2}(9.17 \mathrm{~mL}, 0.17 \mathrm{M})$ was added Dess-Martin Periodinane (992 $\left.\mathrm{mg}, 2.340 \mathrm{mmol}\right)$ at $\mathrm{rt}$. To the stirred suspension was then slowly added $\mathrm{H}_{2} \mathrm{O}(31 \mu \mathrm{L})$. Stirring was continued for 50 min followed by the addition of $\mathrm{Et}_{2} \mathrm{O}(150 \mathrm{~mL})$ and the resulting suspension was gently concentrated in vacuo to a few $\mathrm{mL}$ after which $\mathrm{Et}_{2} \mathrm{O}(100 \mathrm{~mL})$ was added. The ethereal solution was washed with a $1: 1$ mixture of sat. aq. $\mathrm{NaHCO}_{3}$ and $10 \%$ $\mathrm{Na}_{2} \mathrm{~S}_{2} \mathrm{O}_{3}$ until the phases became clear. The aqueous phase was back-extracted with $\mathrm{Et}_{2} \mathrm{O}(2 \times 80 \mathrm{~mL})$ and the combined ethereal phases were dried over $\mathrm{MgSO}_{4}$, filtered and concentrated in vacuo to provide a crude oil that was purified by silica gel chromatography to provide $1 \mathrm{~g}\left(435 \mathrm{mg}, 1.546 \mathrm{mmol}, 99 \%\right.$ yield) as a colorless oil. ${ }^{1} \mathrm{H} \mathrm{NMR}\left(600 \mathrm{MHz} \mathrm{CDCl}_{3}\right) \delta 9.72$ (br, 1H), $7.23-7.20(\mathrm{~m}, 1 \mathrm{H}), 6.97-6.95(\mathrm{~m}, 1 \mathrm{H}), 6.92(\mathrm{br}, 1 \mathrm{H}), 4.00-3.67(\mathrm{~m}, 4 \mathrm{H}), 3.55-3.43(\mathrm{~m}, 1 \mathrm{H}), 3.24-3.16(\mathrm{~m}, 1 \mathrm{H})$, $1.50-1.44(\mathrm{~m}, 9 \mathrm{H}) ;{ }^{13} \mathrm{C} \mathrm{NMR}\left(151 \mathrm{MHz}, \mathrm{CDCl}_{3}\right) \delta 199.68,154.20,142.82,127.29,125.05,124.95,124.62,124.56,80.26$, 58.35, 57.46, 53.29, 52.81, 45.39, 45.22, 40.56, 40.11, 28.65. Mixture of conformers. LRMS: $\left(\mathrm{UV} \mathrm{t}_{\mathrm{R}}=0.72\right) \mathrm{m} / \mathrm{z}=226.0$. HRMS-ESI: $m / z$ for $\mathrm{C}_{14} \mathrm{H}_{20} \mathrm{NO}_{3} \mathrm{~S}\left[\mathrm{MH}^{+}\right]$calcd. 282.1158; found 282.1158. $[\alpha]_{\mathrm{D}}^{22}=-27.6^{\circ}\left(c=1.2, \mathrm{CHCl}_{3}\right)$. 


\section{Relative Configuration of Products}

The relative configuration of the products was assigned using heteronuclear through-space NOE investigation on $p$-chloroaniline derivatives of $\mathbf{2 g}$ and $\mathbf{3 g}$, namely $\mathbf{2 g}$-deriv and $\mathbf{3 g}$-deriv. As indicated below, the fluorine atom only interacts with the thienyl proton in the syn-product $\mathbf{2 g}$-deriv. The relative configurations of the other fluorinated products were assigned analogously.

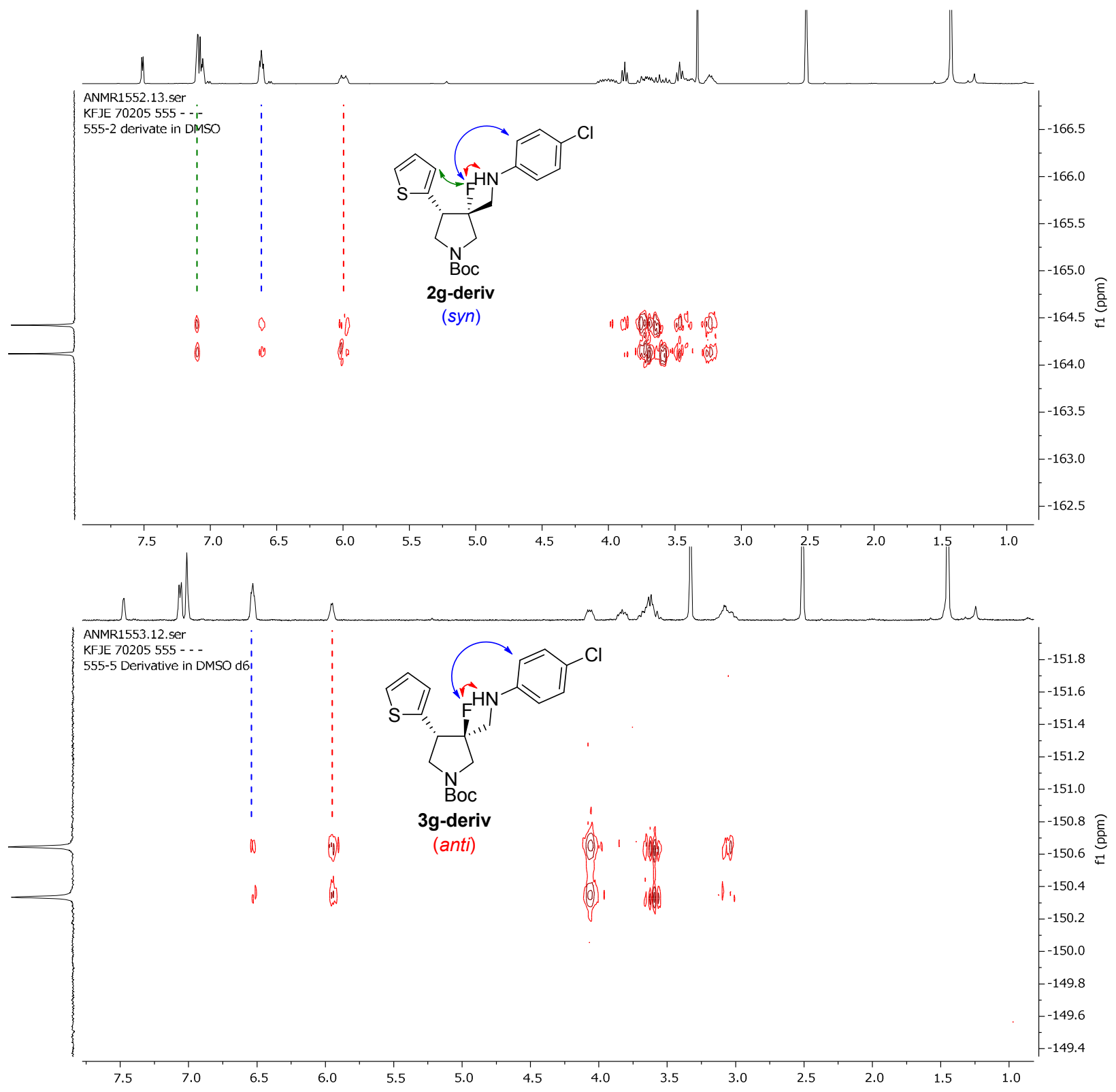

Formation of the reduced amines $\mathbf{2 g - d e r i v}$ and $\mathbf{3 g}$-deriv: To a solution of $\mathbf{2 g}$ or $\mathbf{3 g}$ (19mg, $0.063 \mathrm{mmol})$ in 1,2-dichloroethane (2 $\mathrm{mL}$ ) was added 4-chloroaniline $(8.1 \mathrm{mg}, 0.063 \mathrm{mmol})$ followed by sodium triacetoxyborohydride $(19 \mathrm{mg}, 0.089 \mathrm{mmol}) \mathrm{and}$ the mixture was stirred at $\mathrm{rt}$ for $16 \mathrm{~h}$ followed by the addition of $\mathrm{NaBH}_{4}(2.4 \mathrm{mg}, 0.063 \mathrm{mmol})$ and continued stirring for $1 \mathrm{~h}$. Subsequently, sat. aq. $\mathrm{NaHCO}_{3}(1.5 \mathrm{~mL})$ was added and the phases were separated followed by extraction of the aqueous phase with $\mathrm{CH}_{2} \mathrm{Cl}_{2}(2 \times 3 \mathrm{~mL})$ after which the combined organic layers were dried over $\mathrm{Na}_{2} \mathrm{SO}_{4}$, filtered and concentrated in vacuo to provide a crude residue that was purified using silica gel chromatography to provide the reduced amine $\mathbf{2 g - d e r i v}$ or $\mathbf{3 g}$-deriv.

2g-deriv (12 mg, $0.029 \mathrm{mmol}, 46 \%$ yield) as a yellow oil. ${ }^{1} \mathrm{H}$ NMR (500 MHz, DMSO-d6) $\delta 7.51(\mathrm{~d}, J=5.1 \mathrm{~Hz}, 1 \mathrm{H}), 7.13-7.04$ (m, 4H), $6.65-6.58(\mathrm{~m}, 2 \mathrm{H}), 6.04-5.95(\mathrm{~m}, 1 \mathrm{H}), 4.10-3.93(\mathrm{~m}, 1 \mathrm{H}), 3.91-3.85(\mathrm{~m}, 1 \mathrm{H}), 3.78-3.53(\mathrm{~m}, 2 \mathrm{H}), 3.50-3.35(\mathrm{~m}$, 
2H), $1.43-1.40(\mathrm{~m}, 9 \mathrm{H}) .{ }^{13} \mathrm{C}$ NMR $(151 \mathrm{MHz}, \mathrm{DMSO}-d 6) \delta 152.7,152.6,146.9,146.9,135.5,135.3,127.9,127.8,127.1,126.2$, $126.2,126.2,125.3,125.3,118.9,118.8,114.5,113.0,112.9,102.4,101.8,101.2,100.6,78.4,53.8,53.7,53.5,53.4,50.6,50.3$, 44.8, 44.6, 44.5, 44.3, 44.1, 44.0, 43.4, 43.3, 27.5, 27.4 (conformers). ${ }^{19} \mathrm{~F}$ NMR (471 MHz, DMSO-d6) $\delta$-164.12, -164.42 (two conformers). HRMS-ESI: $m / z$ for $\mathrm{C}_{20} \mathrm{H}_{25} \mathrm{ClFN}_{2} \mathrm{O}_{2} \mathrm{~S}$ [MH ${ }^{+}$calcd. 411.1304; found 411.1296.

3g-deriv (9 mg, $0.022 \mathrm{mmol}, 35 \%$ yield) as a yellow oil. ${ }^{1} \mathrm{H}$ NMR (600 MHz, DMSO-d6) $\delta 7.49-7.45(\mathrm{~m}, 1 \mathrm{H}), 7.08-7.04(\mathrm{~m}$, $2 \mathrm{H}), 7.02-6.99(\mathrm{~m}, 2 \mathrm{H}), 6.55-6.49(\mathrm{~m}, 2 \mathrm{H}), 5.99-5.94(\mathrm{~m}, 1 \mathrm{H}), 4.10-4.02(\mathrm{~m}, 1 \mathrm{H}), 3.86-3.77(\mathrm{~m}, 1 \mathrm{H}), 3.70-3.53(\mathrm{~m}$, $3 \mathrm{H}), 3.13-2.98(\mathrm{~m}, 2 \mathrm{H}), 1.47-1.42(\mathrm{~m}, 9 \mathrm{H}) .{ }^{13} \mathrm{C}$ NMR $(151 \mathrm{MHz}, \mathrm{DMSO}-d 6) \delta 152.9,152.8,147.0,146.9,139.5,139.4$, 127.8, 126.4, 125.8, 125.7, 124.9, 124.9, 118.8, 118.7, 112.9, 112.9, 104.7, 104.1, 103.5, 102.9, 78.6, 78.6, 51.7, 51.5, 51.4, 51.1, 50.6, 45.4, 45.2, 44.6, 44.6, 44.5, 27.5, 27.5 (conformers). ${ }^{19} \mathrm{~F}$ NMR (471 MHz, DMSO-d6) $\delta$-150.33, -150.64 (two conformers). HRMS-ESI: $m / z$ for $\mathrm{C}_{20} \mathrm{H}_{25} \mathrm{ClFN}_{2} \mathrm{O}_{2} \mathrm{~S}\left[\mathrm{MH}^{+}\right]$calcd. 411.1304 ; found 411.1302 . 
Screening of Additional Catalysts

The expanded screening of organocatalysts were performed on the enantiomer of $\mathbf{1 a}((3 S, 4 R)-\mathbf{1 a})$. Both the conversion and crude dr provided are obtained by LCMS after reduction to the alcohol.

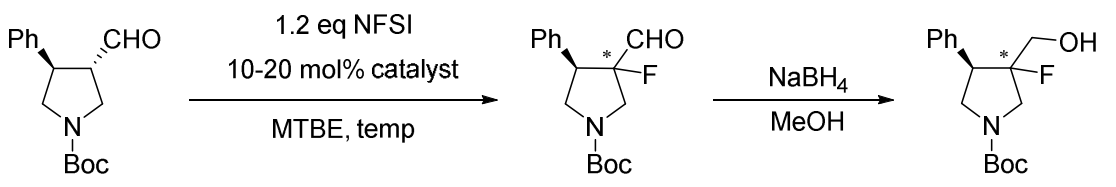

\begin{tabular}{|c|c|c|c|c|}
\hline Entry & Catalyst & $\begin{array}{c}\text { Temp } \\
{\left[{ }^{\circ} \mathrm{C}\right]}\end{array}$ & $\begin{array}{c}\text { Conversion } \\
{[\%]}\end{array}$ & $\begin{array}{c}\text { D.r. } \\
\text { (fast : slow - TIC) }\end{array}$ \\
\hline 1 & & 21 & - & $16: 84$ \\
\hline 2 & & 21 & - & $3: 97$ \\
\hline 3 & & 40 & 0 & - \\
\hline 4 & $\cdot \mathrm{HC}$ & 40 & $\sim 50$ & $93: 7$ \\
\hline 5 & 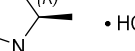 & 40 & $\sim 40$ & $66: 34$ \\
\hline 6 & $\cdot H$ & 21 & $\sim 15$ & $65: 35$ \\
\hline 7 & & 40 & $\sim 45$ & $70: 30$ \\
\hline 8 & & 40 & $\sim 33$ & $89: 11$ \\
\hline 9 & & 40 & $\sim 33$ & $78: 22$ \\
\hline 10 & & 40 & $\sim 66$ & $69: 31$ \\
\hline
\end{tabular}


11

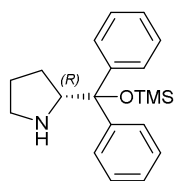

12

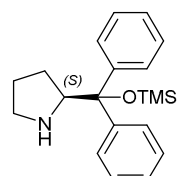

13

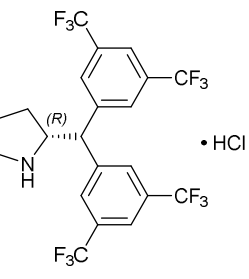

$\mathrm{F}_{3} \mathrm{C}$

14

15

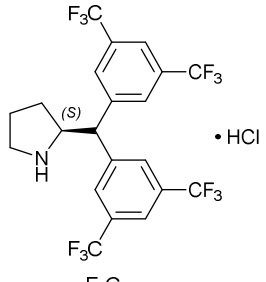

$\mathrm{F}_{3} \mathrm{C}$

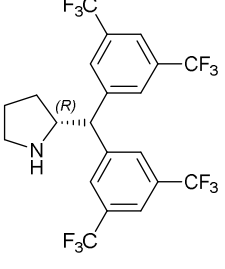

$\mathrm{F}_{3} \mathrm{C}$

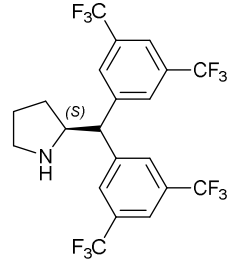

21

21

21

$\sim 45$

$73: 27$

$\sim 6$

$97: 3$

21

$\sim 20$

$28: 72$

40

$\sim 40$

$95: 5$

40

$\sim 85$

$30: 70$ 


\section{Chiral SFC Data}

Determination of $e e$ for $\mathbf{1 1 b}$.

\section{Enantioenriched sample:}

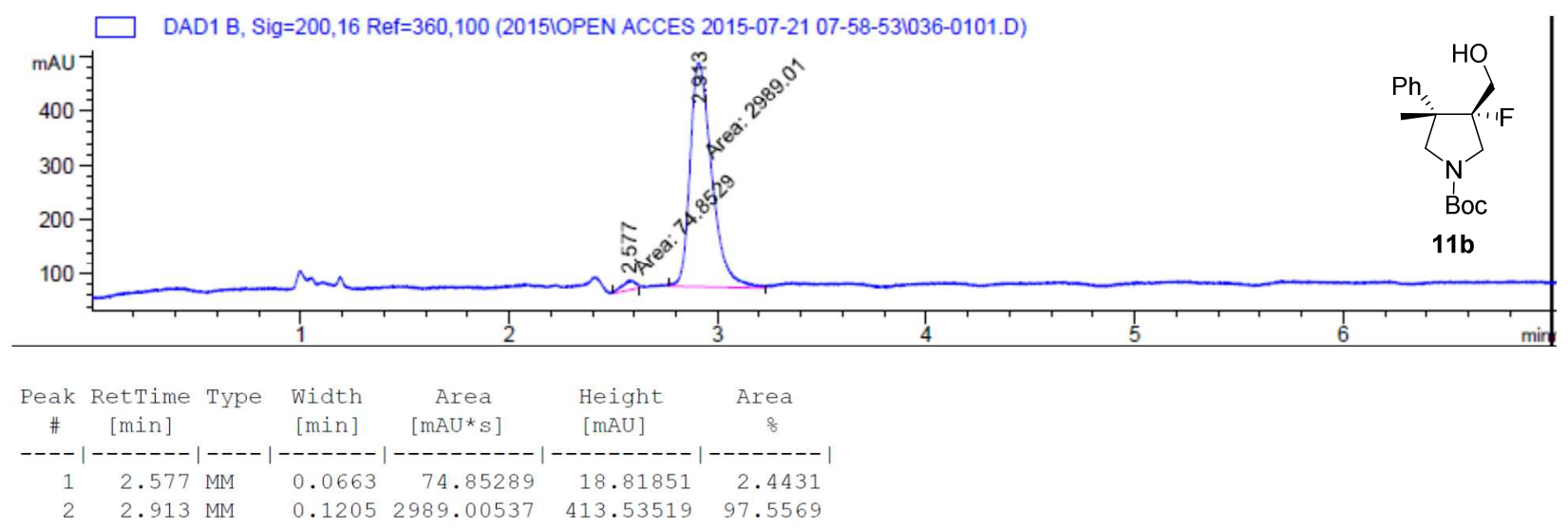

\section{Racemic sample:}

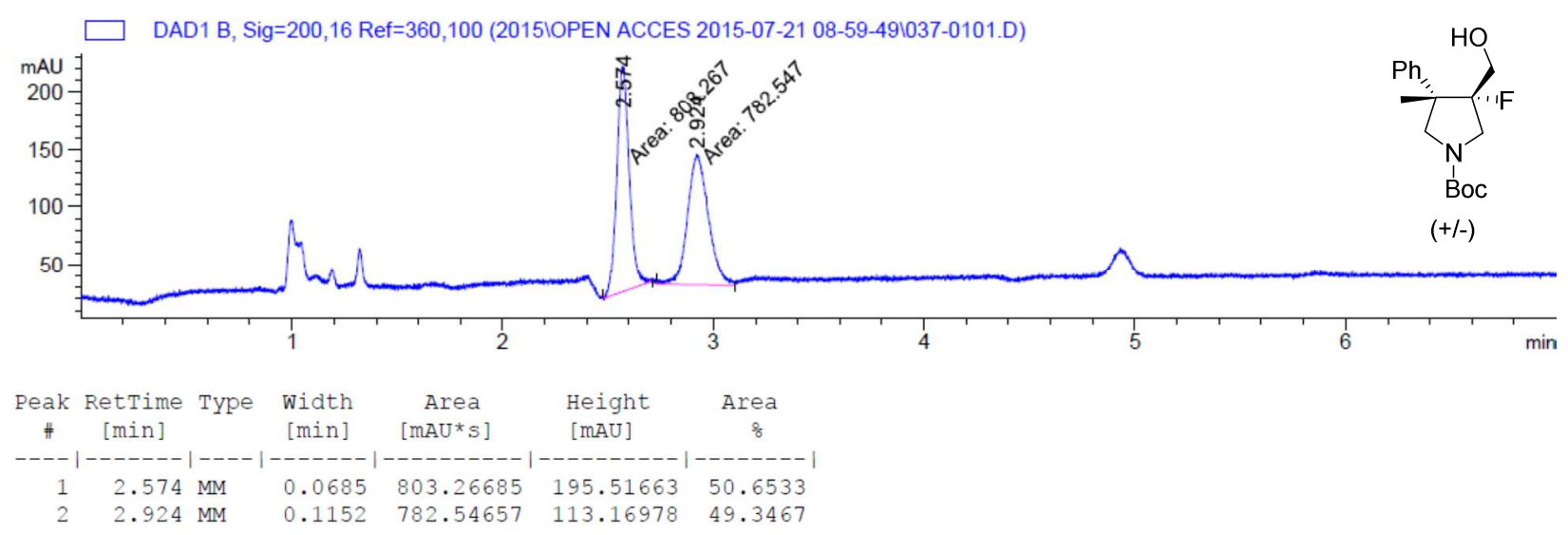

Determination of $e e$ for $\mathbf{1 2}$

\section{Enantioenriched sample:}

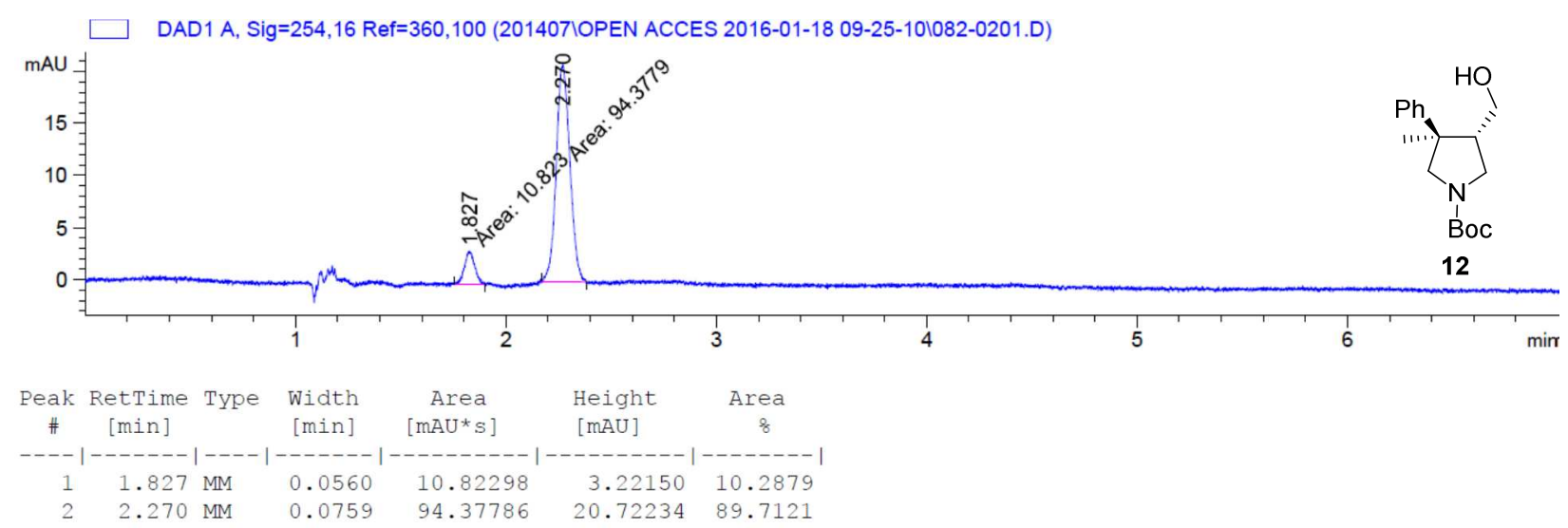




\section{Racemic sample:}

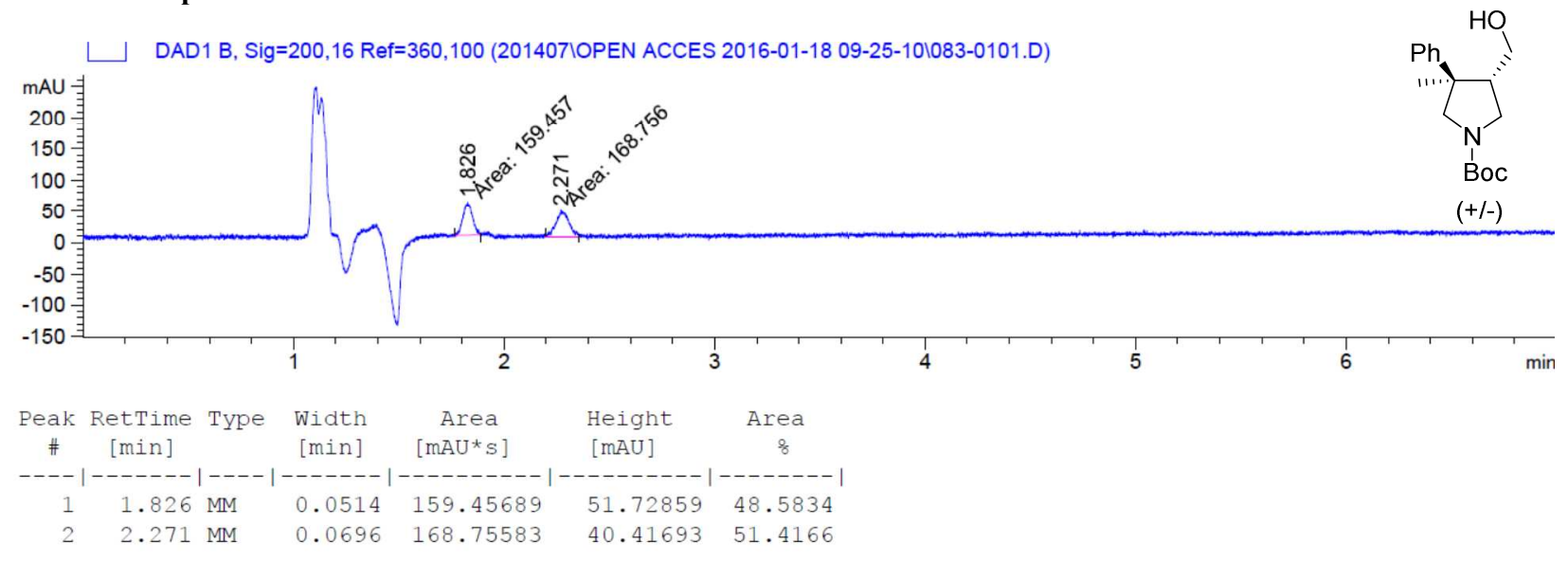


NMR Spectre

tert-Butyl (3S,4S)-3-fluoro-3-formyl-4-phenylpyrrolidine-1-carboxylate (2a)

The NMR data was acquired at 600,151 or $471 \mathrm{MHz}$ for ${ }^{1} \mathrm{H},{ }^{13} \mathrm{C}$ or ${ }^{19} \mathrm{~F}$ NMR respectively in $\mathrm{CDCl}_{3}$.

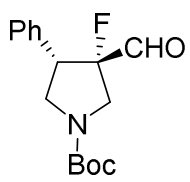

$2 \mathbf{a}$

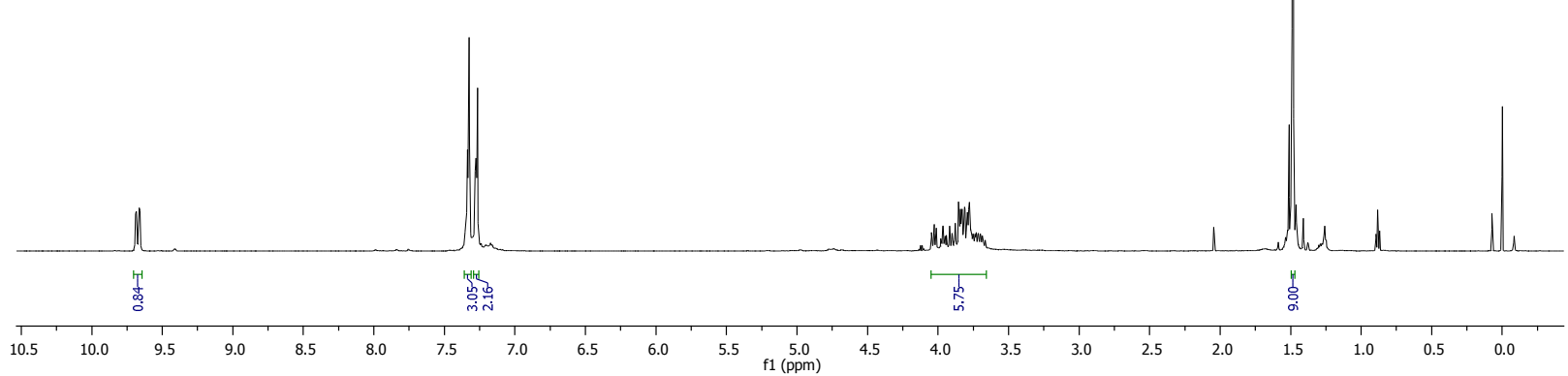

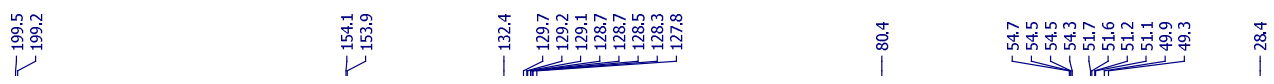

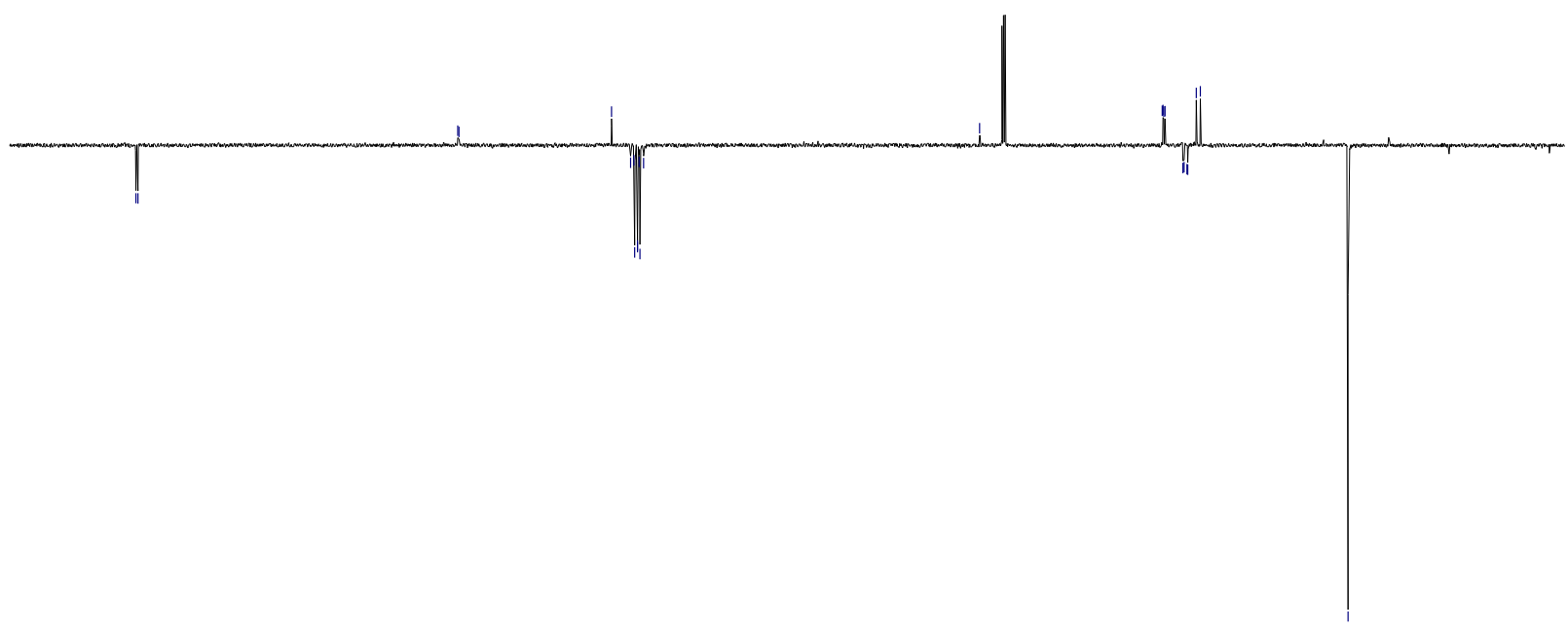

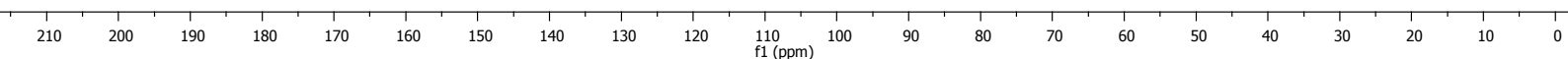




\section{tert-Butyl (3R,4S)-3-fluoro-3-formyl-4-phenylpyrrolidine-1-carboxylate (3a)}

The NMR data was acquired at 600,151 or $471 \mathrm{MHz}$ for ${ }^{1} \mathrm{H},{ }^{13} \mathrm{C}$ or ${ }^{19} \mathrm{~F}$ NMR respectively in $\mathrm{CDCl}_{3}$.

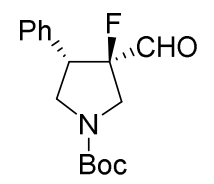

$3 a$
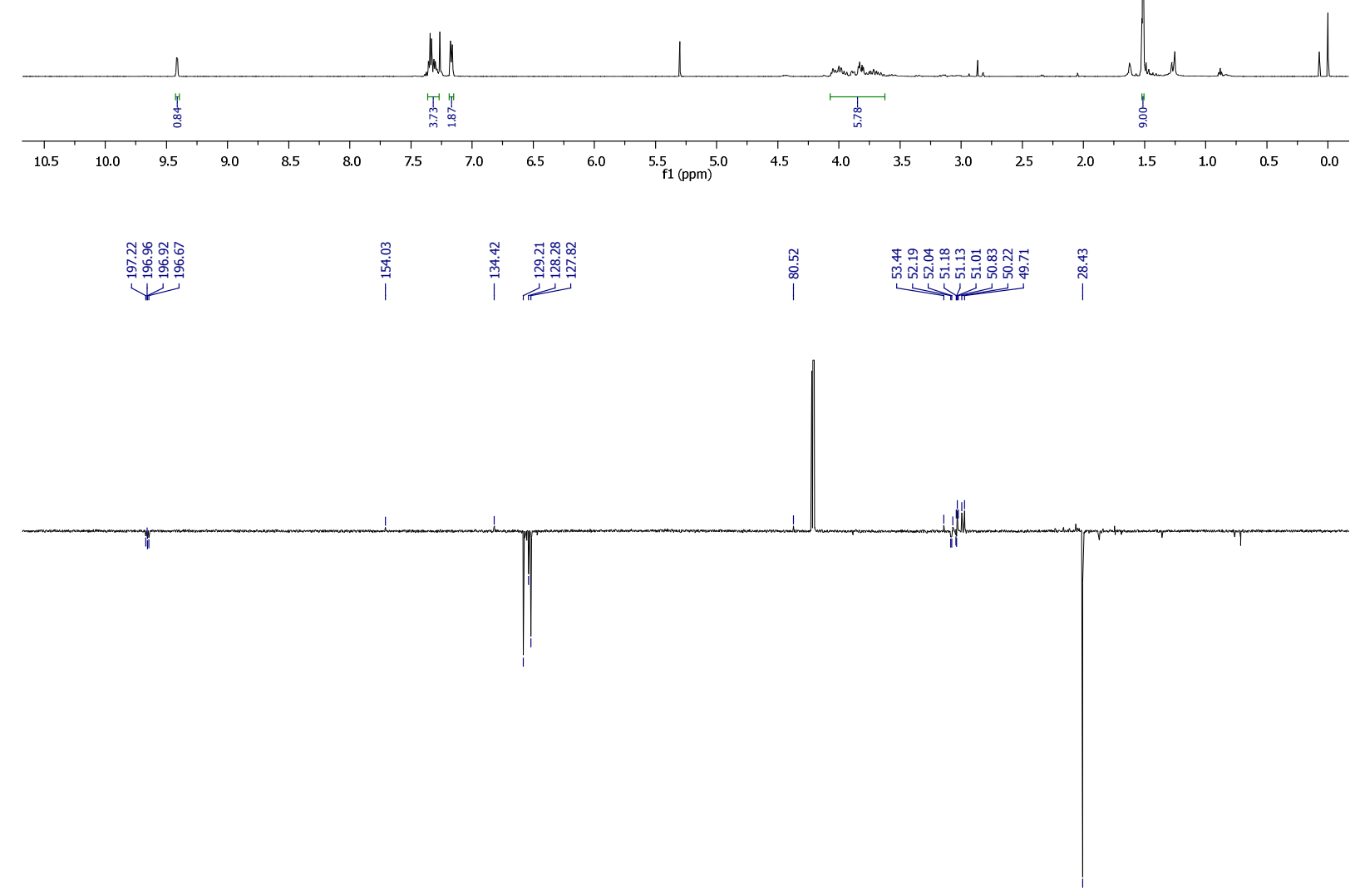

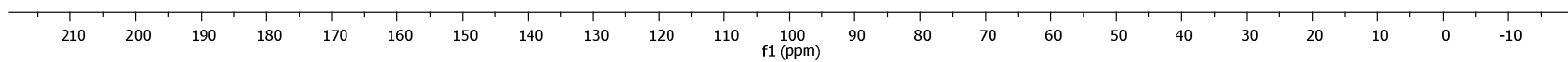


웅영

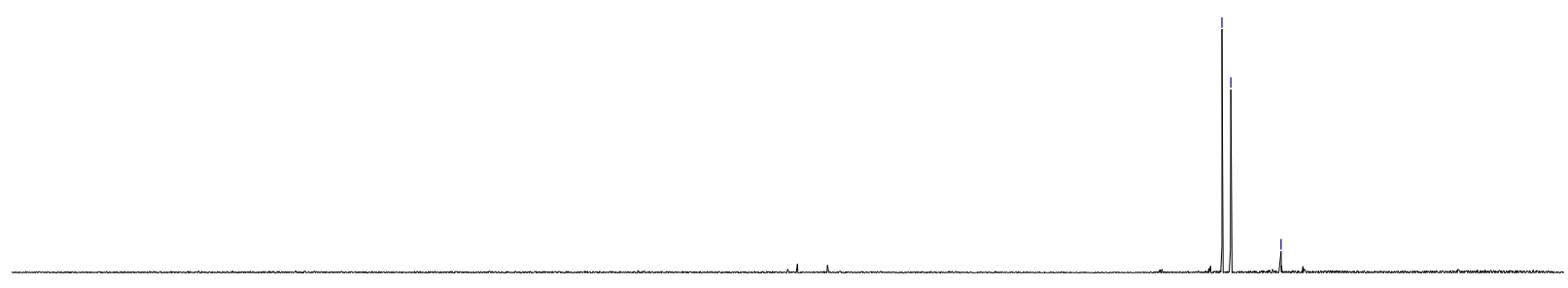


tert-Butyl (3S,4S)-3-fluoro-3-formyl-4-methyl-4-phenylpyrrolidine-1-carboxylate (11b)

The NMR data was acquired at 600,151 or $471 \mathrm{MHz}$ for ${ }^{1} \mathrm{H},{ }^{13} \mathrm{C}$ or ${ }^{19} \mathrm{~F}$ NMR respectively in $\mathrm{CDCl}_{3}$.

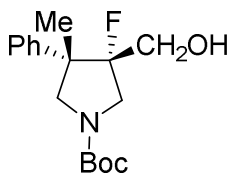

$11 \mathrm{~b}$

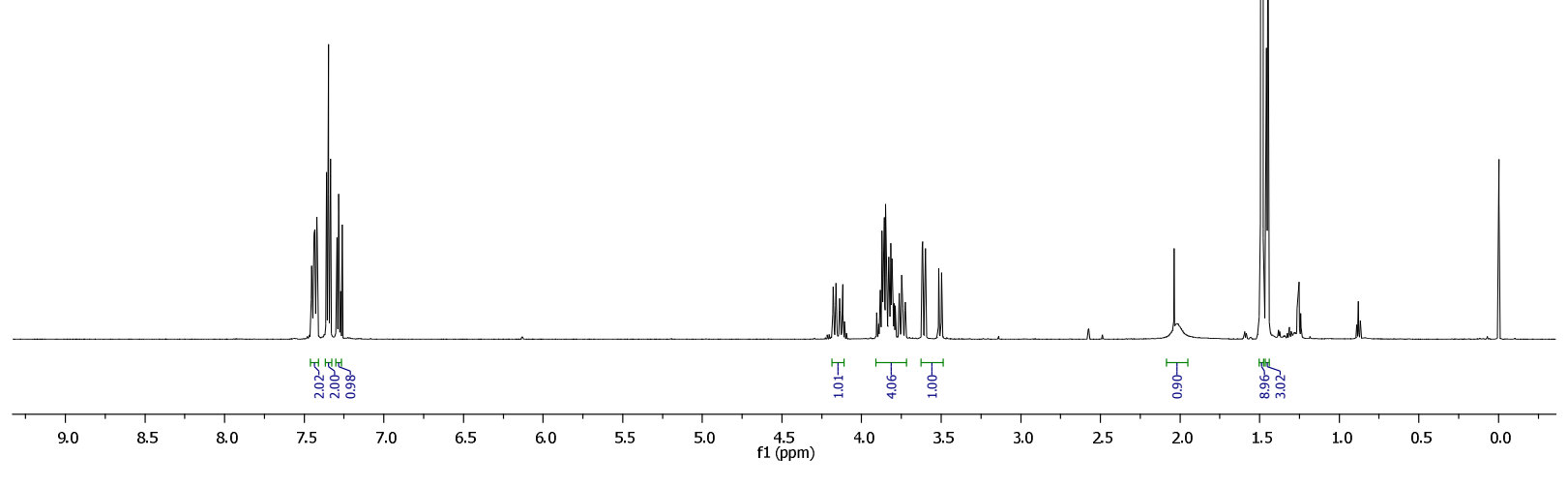

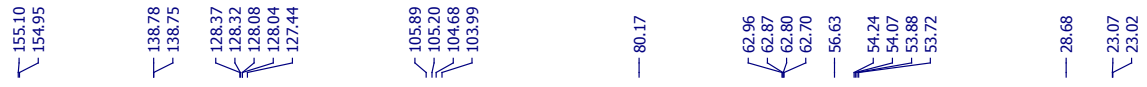

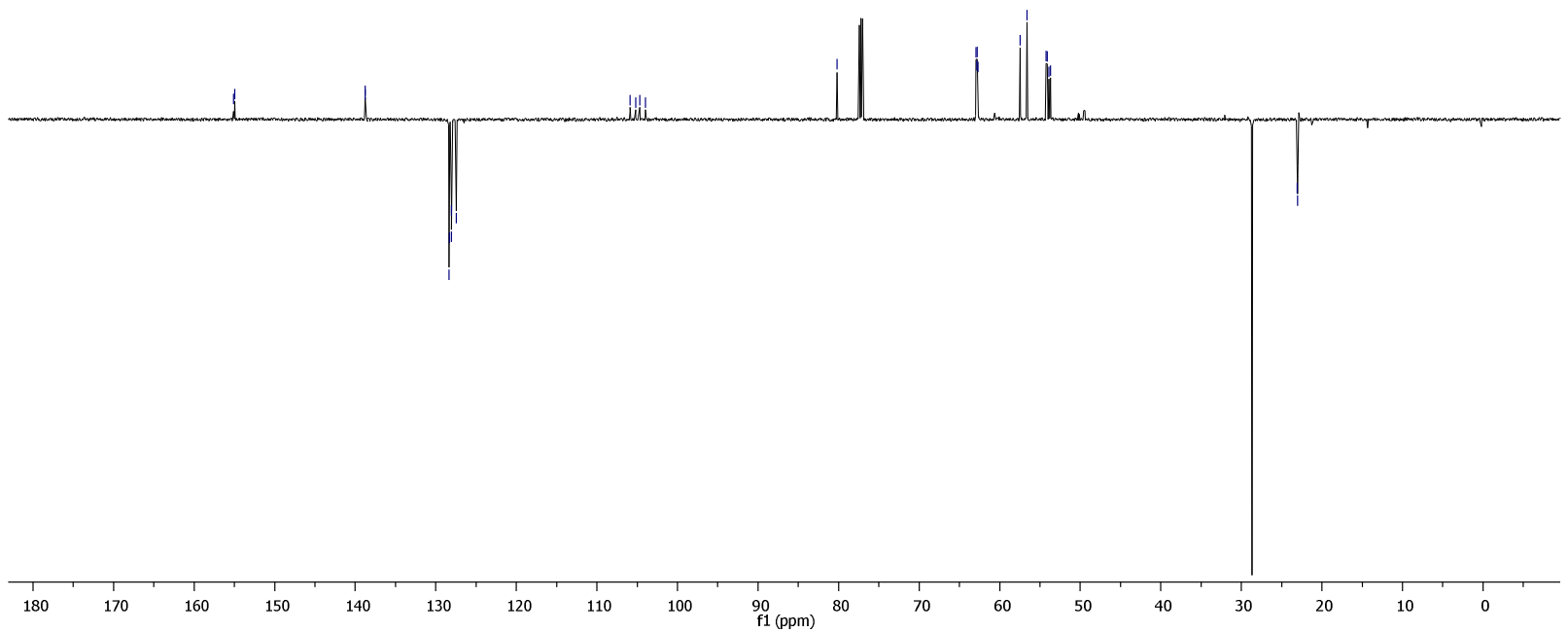




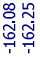

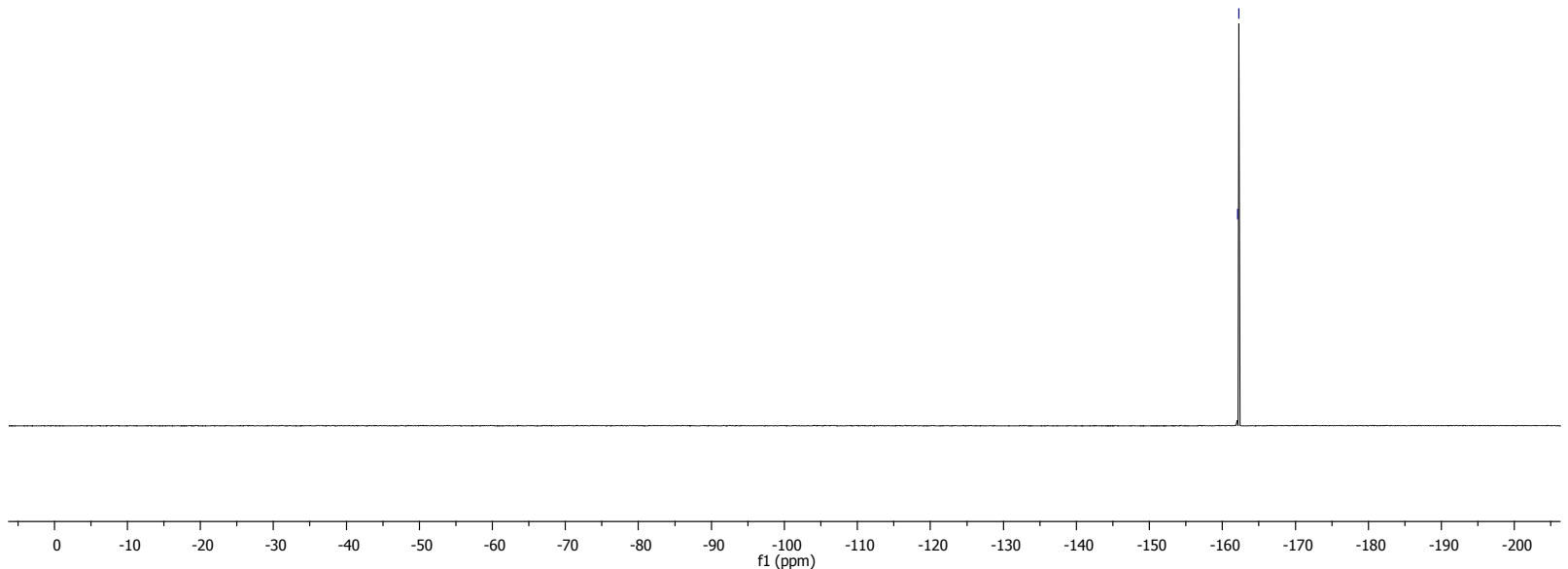




\section{tert-Butyl $(3 R, 4 S)$-3-fluoro-3-formyl-4-methyl-4-phenylpyrrolidine-1-carboxylate (3b)}

The NMR data was acquired at 600,151 or $471 \mathrm{MHz}$ for ${ }^{1} \mathrm{H},{ }^{13} \mathrm{C}$ or ${ }^{19} \mathrm{~F}$ NMR respectively in $\mathrm{CDCl}_{3}$.

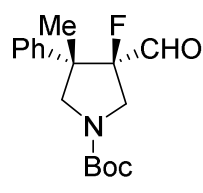

3b

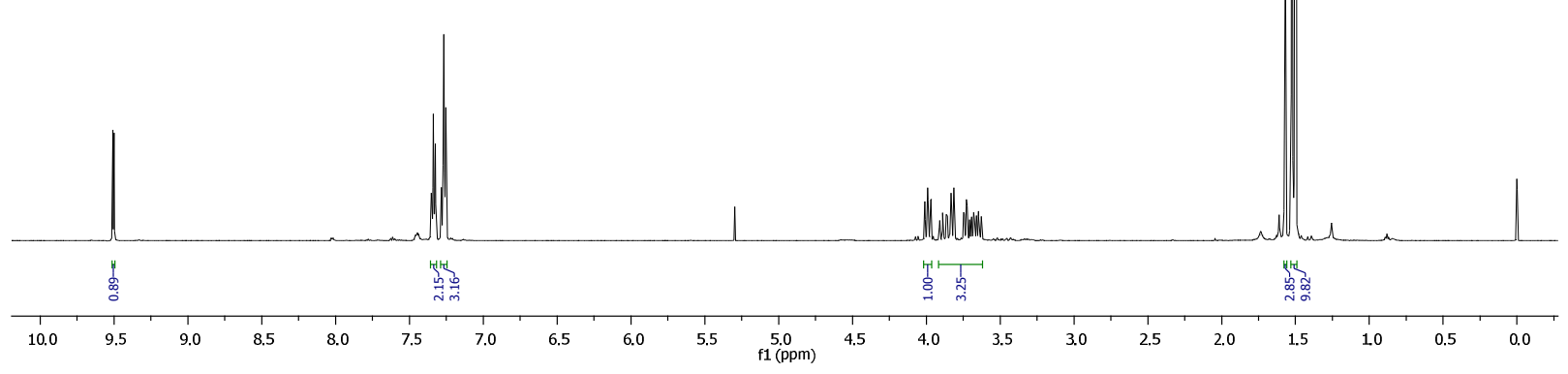

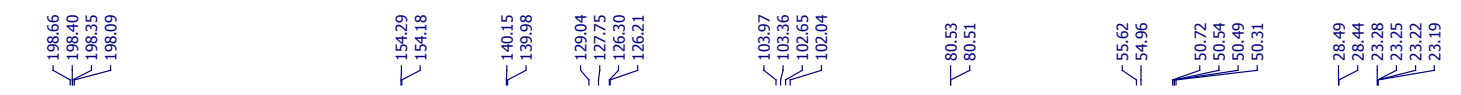

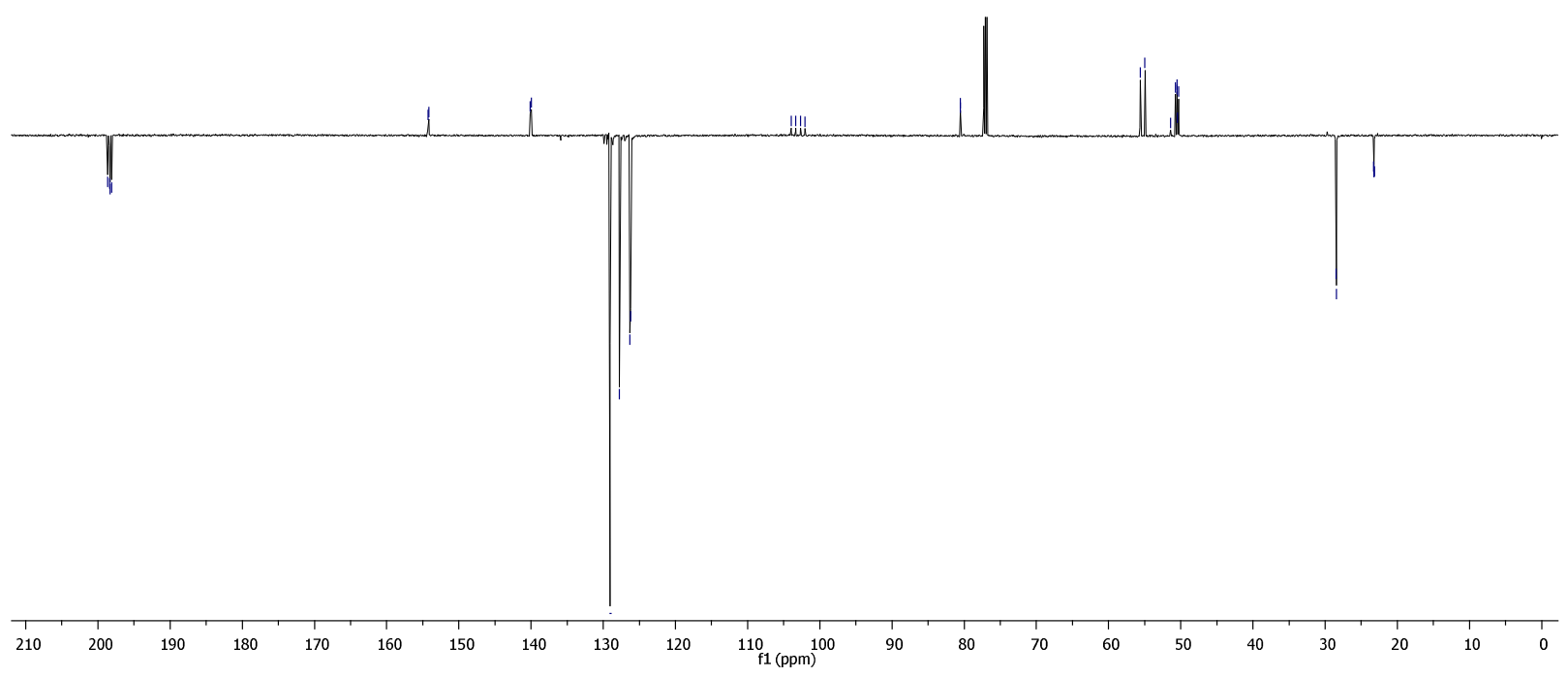




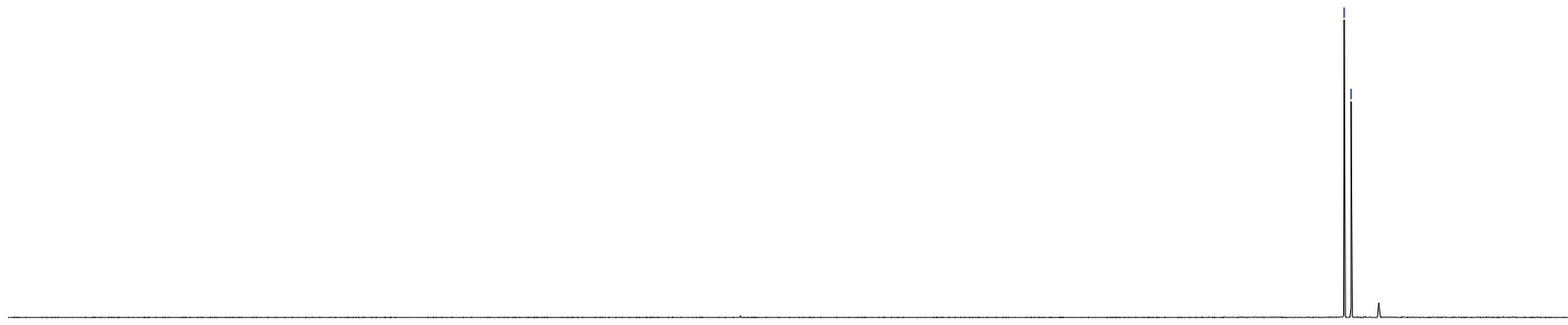

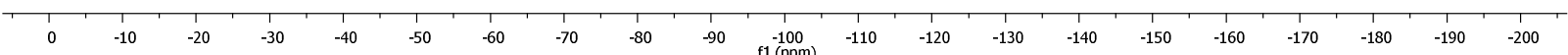




\section{tert-Butyl (3S,4S)-3-fluoro-3-formyl-4-methylpyrrolidine-1-carboxylate (2c)}

The NMR data was acquired at 600,151 or $471 \mathrm{MHz}$ for ${ }^{1} \mathrm{H},{ }^{13} \mathrm{C}$ or ${ }^{19} \mathrm{~F}$ NMR respectively in $\mathrm{CDCl}_{3}$.
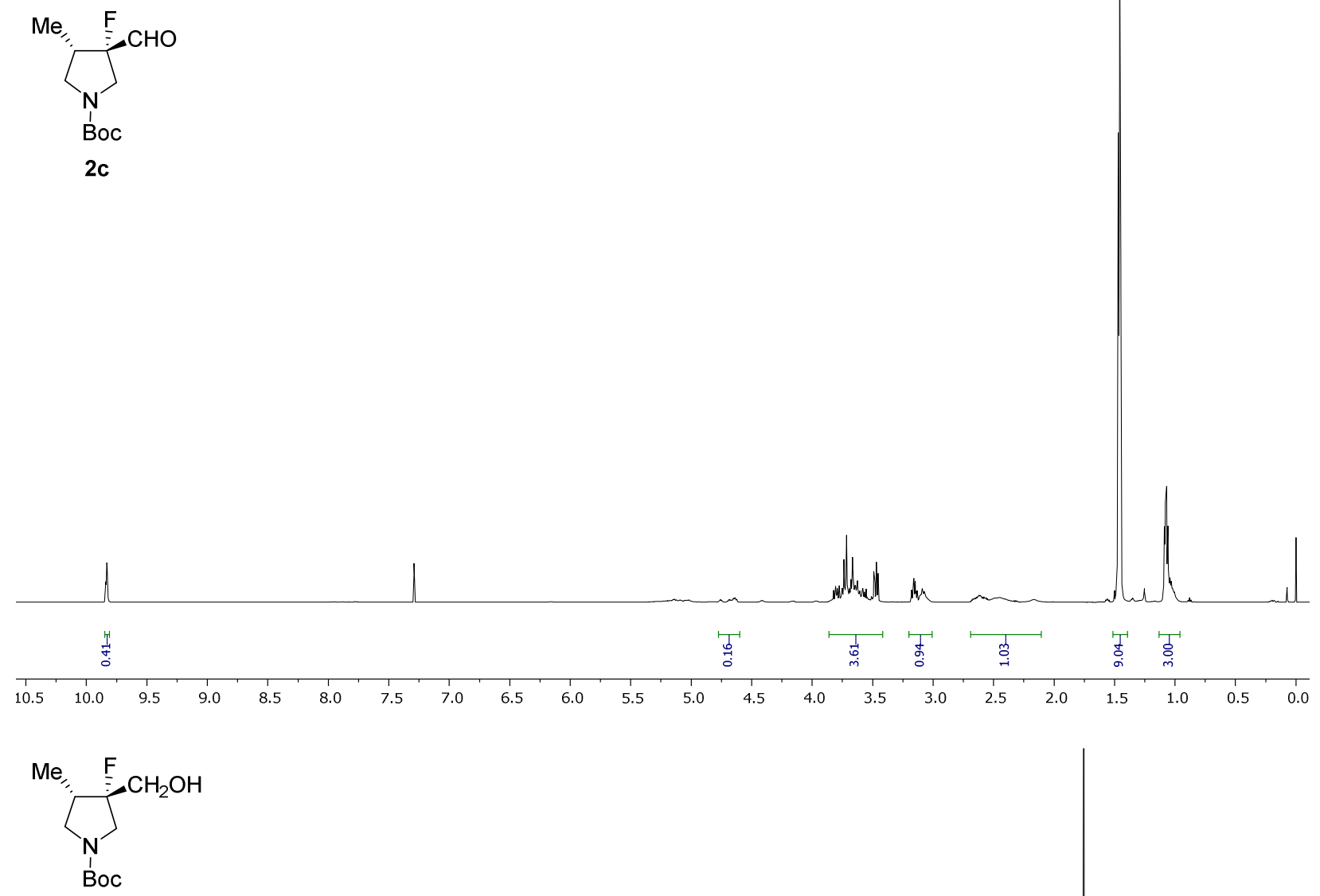

11c

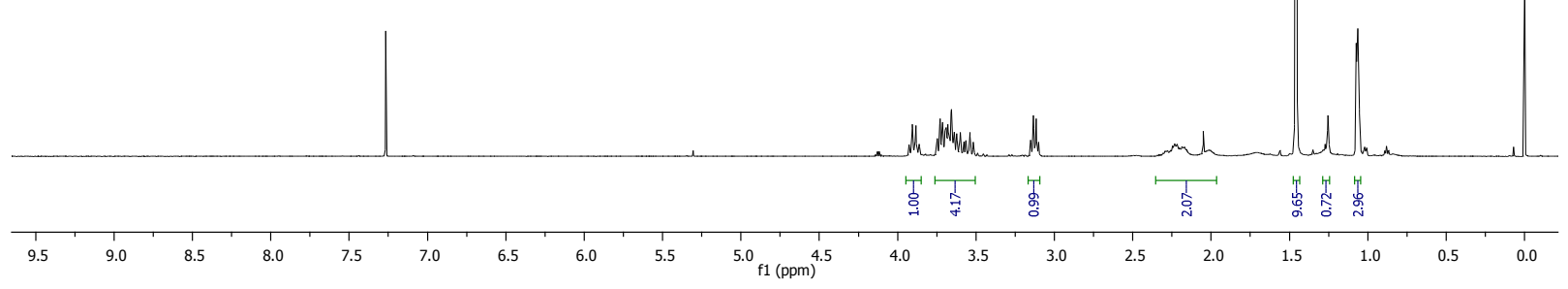



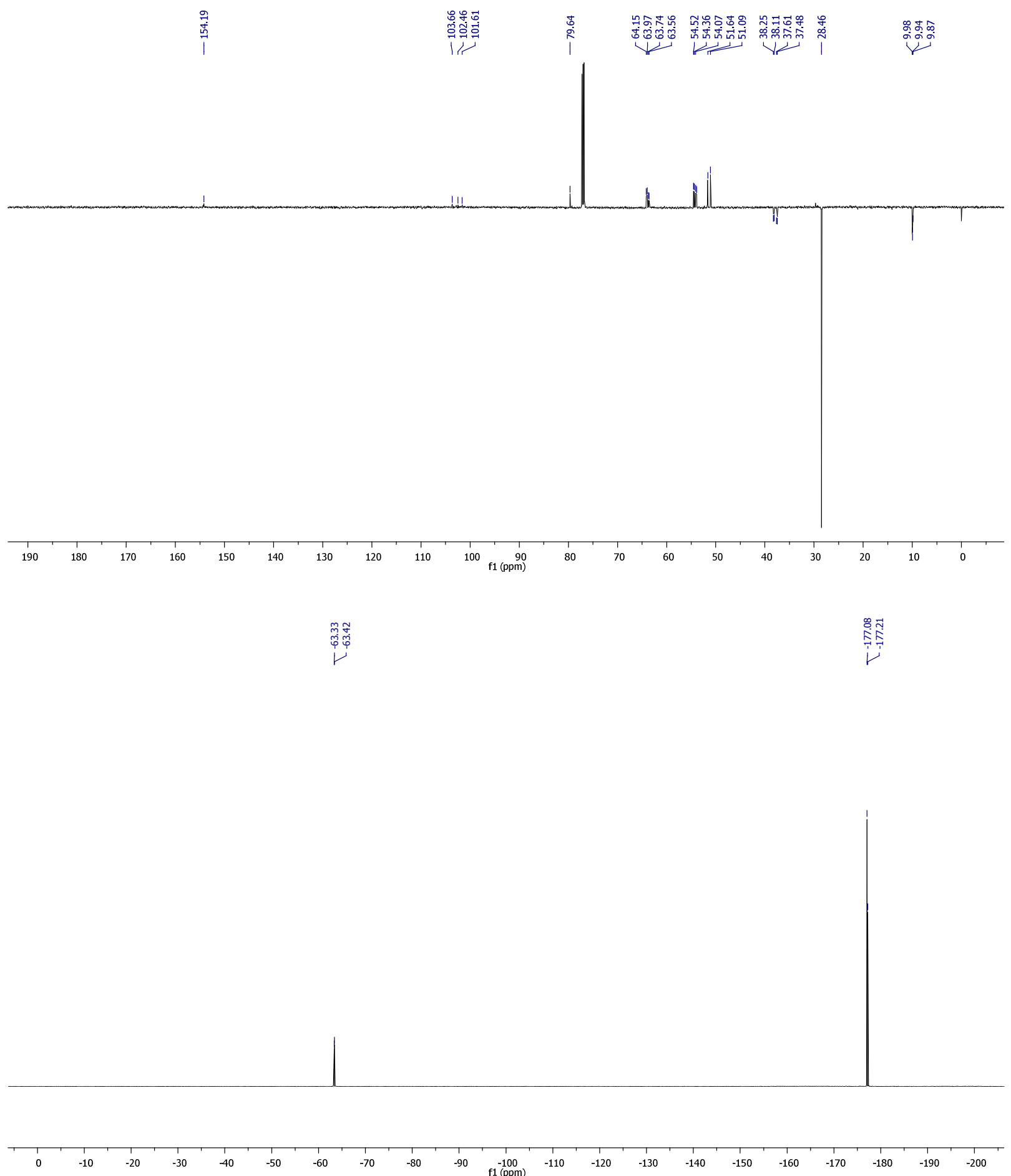


\section{tert-Butyl $(3 R, 4 S)$-3-fluoro-3-formyl-4-methylpyrrolidine-1-carboxylate (3c)}

The NMR data was acquired at 600,151 or $471 \mathrm{MHz}$ for ${ }^{1} \mathrm{H},{ }^{13} \mathrm{C}$ or ${ }^{19} \mathrm{~F}$ NMR respectively in $\mathrm{CDCl}_{3}$.
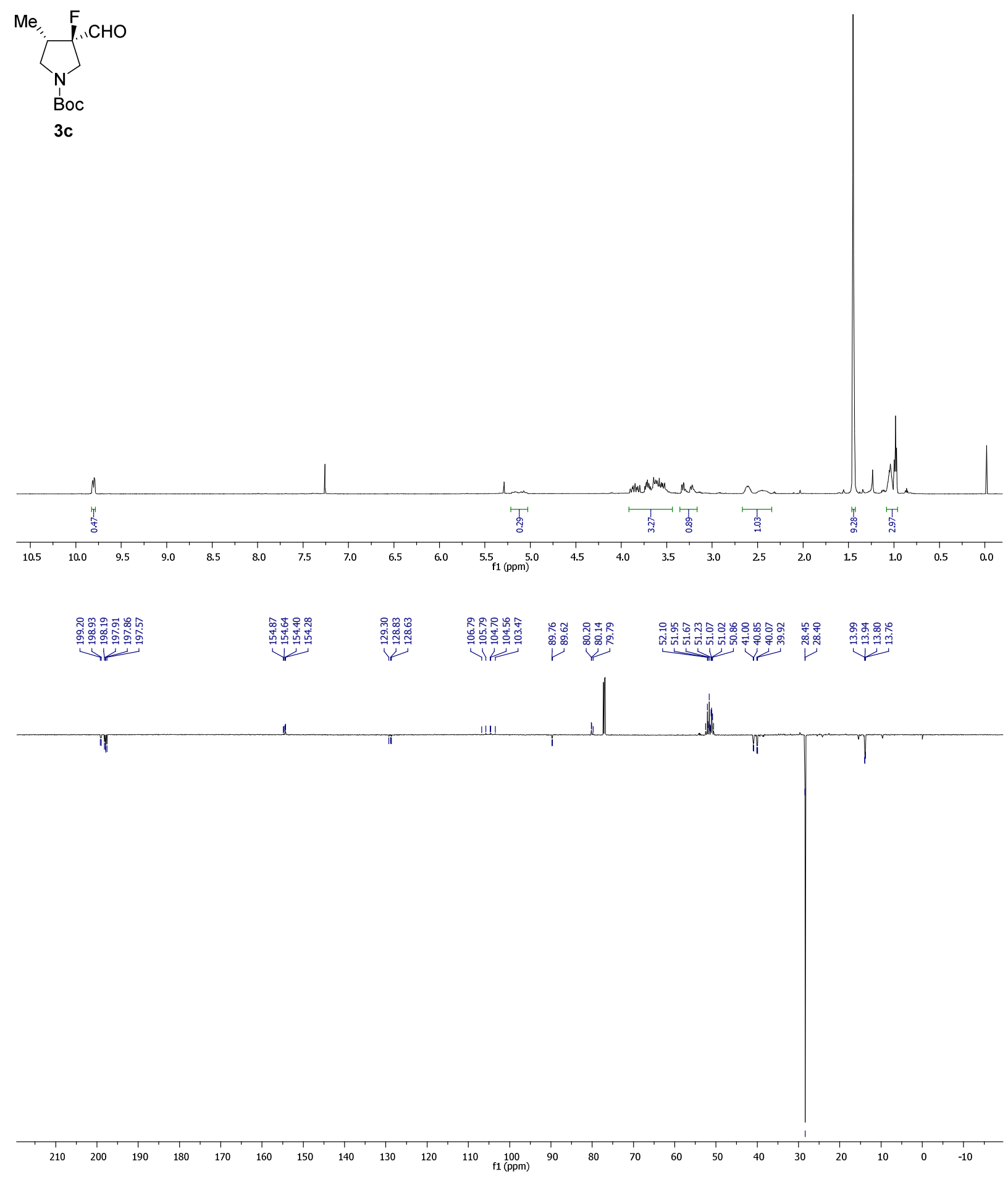


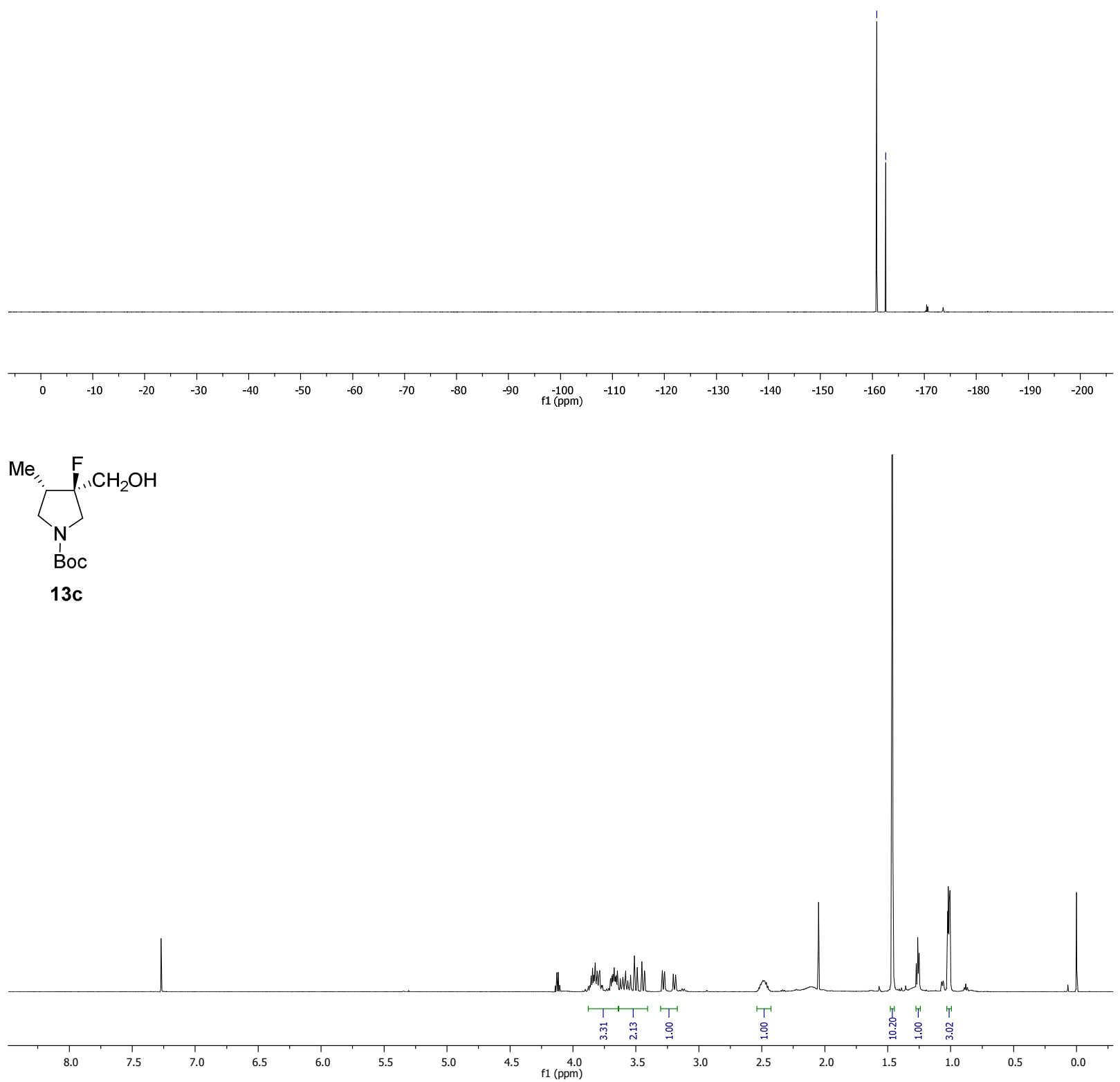




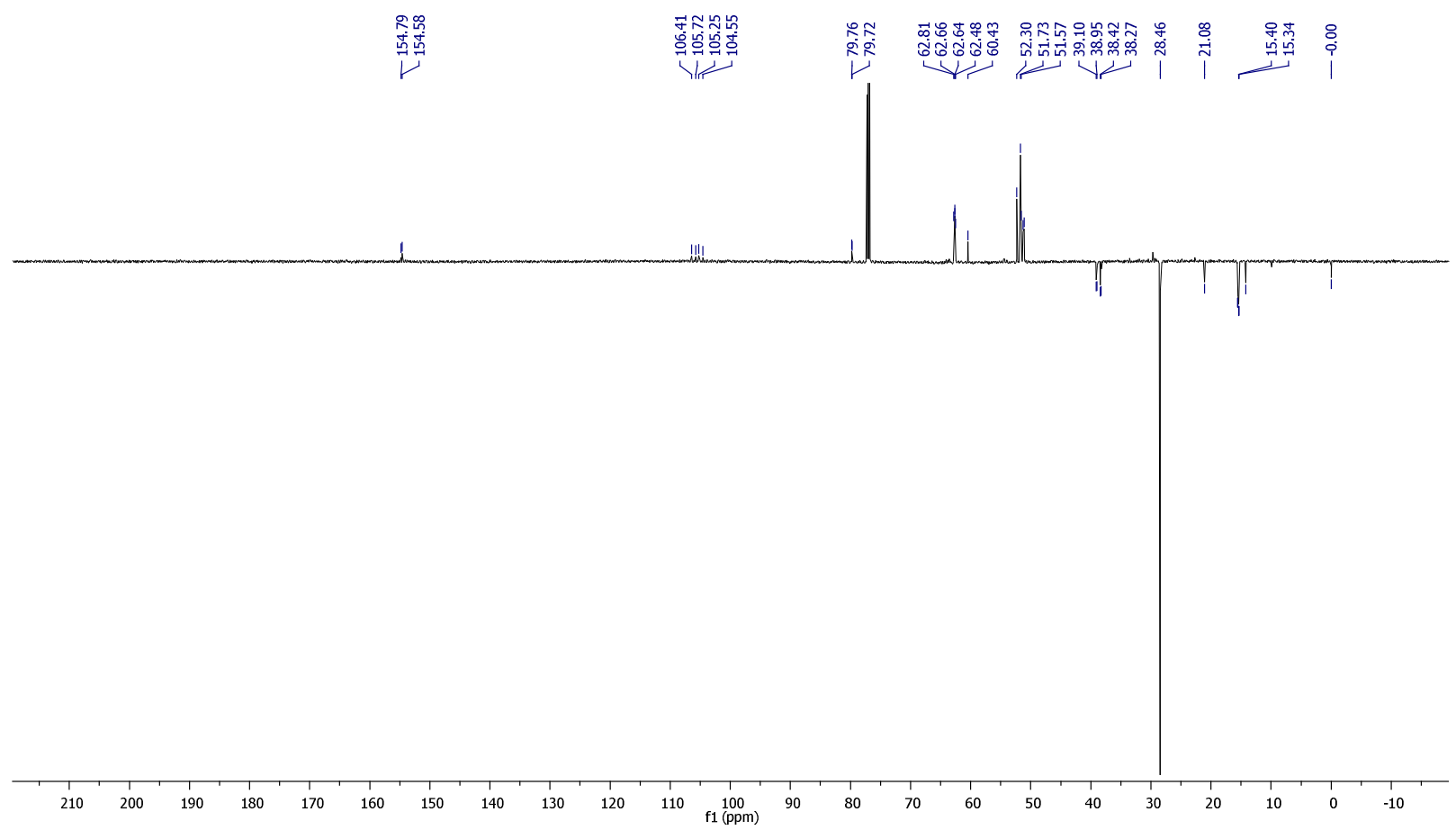




\section{tert-Butyl (3S,4S)-4-benzyl-3-fluoro-3-formylpyrrolidine-1-carboxylate (2d)}

The NMR data was acquired at 600,151 or $471 \mathrm{MHz}$ for ${ }^{1} \mathrm{H},{ }^{13} \mathrm{C}$ or ${ }^{19} \mathrm{~F}$ NMR respectively in $\mathrm{CDCl}_{3}$.

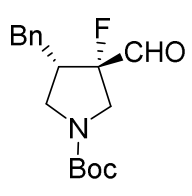

2d

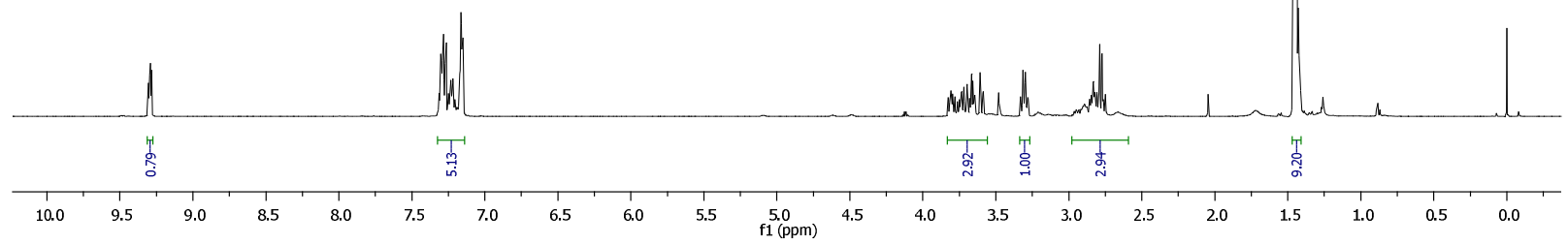

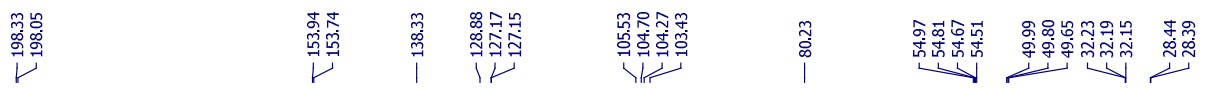

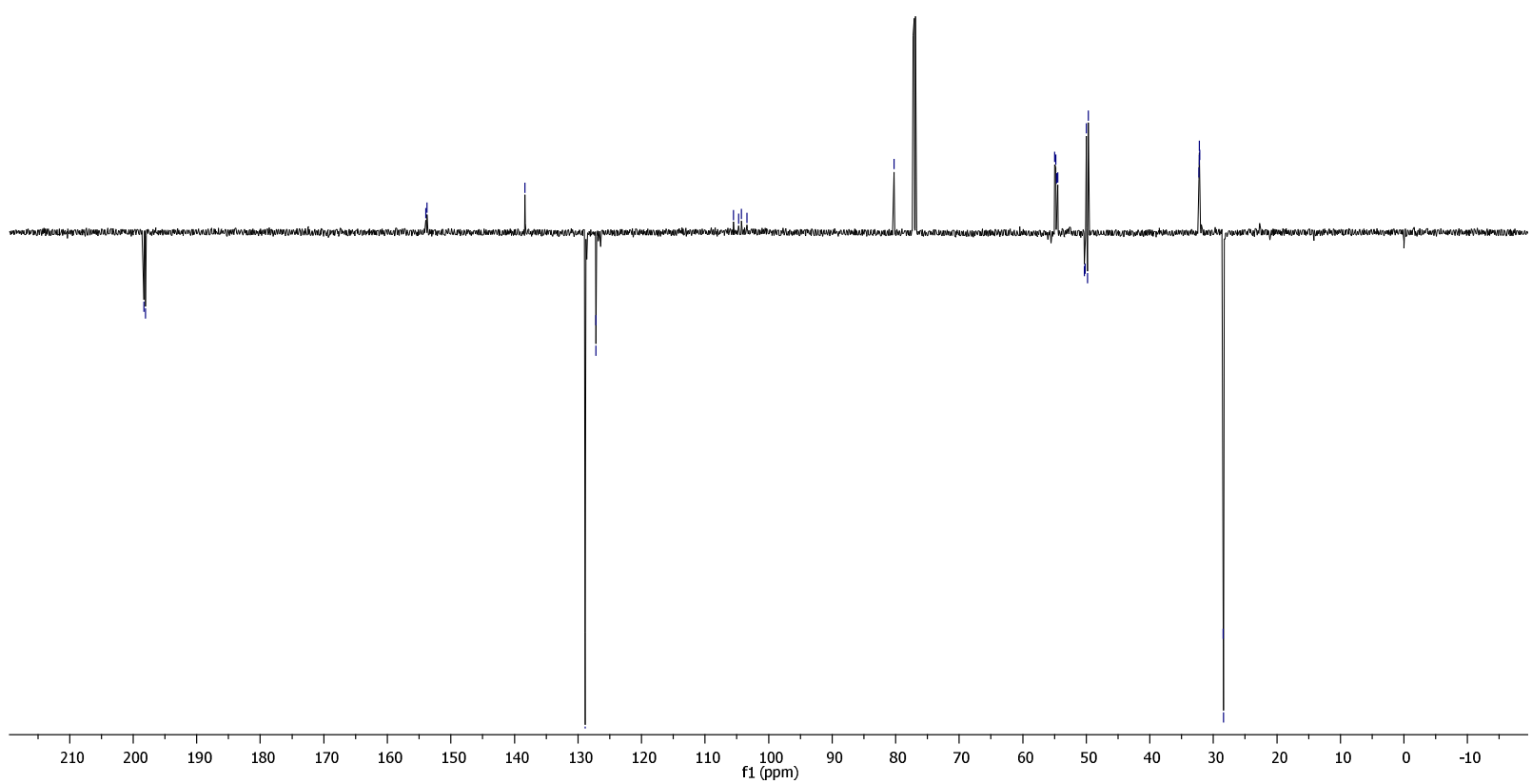




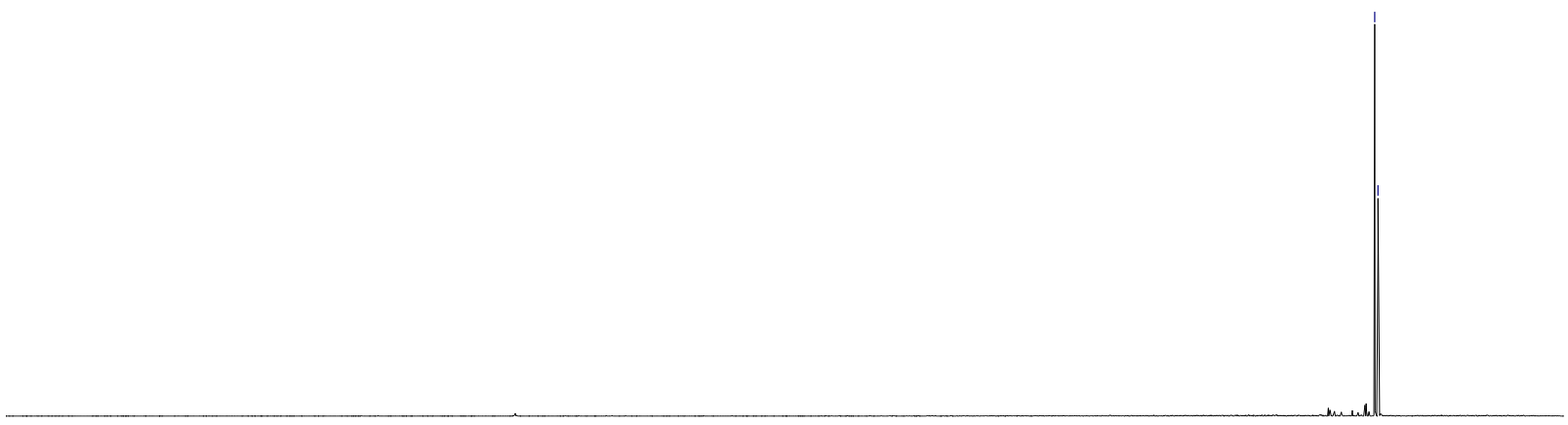

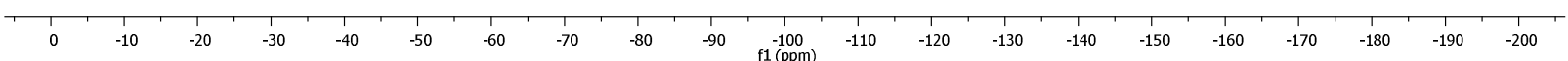




\section{tert-Butyl $(3 R, 4 S)$-4-benzyl-3-fluoro-3-formylpyrrolidine-1-carboxylate (3d)}

The NMR data was acquired at 600,151 or $471 \mathrm{MHz}$ for ${ }^{1} \mathrm{H},{ }^{13} \mathrm{C}$ or ${ }^{19} \mathrm{~F}$ NMR respectively in $\mathrm{CDCl}_{3}$.
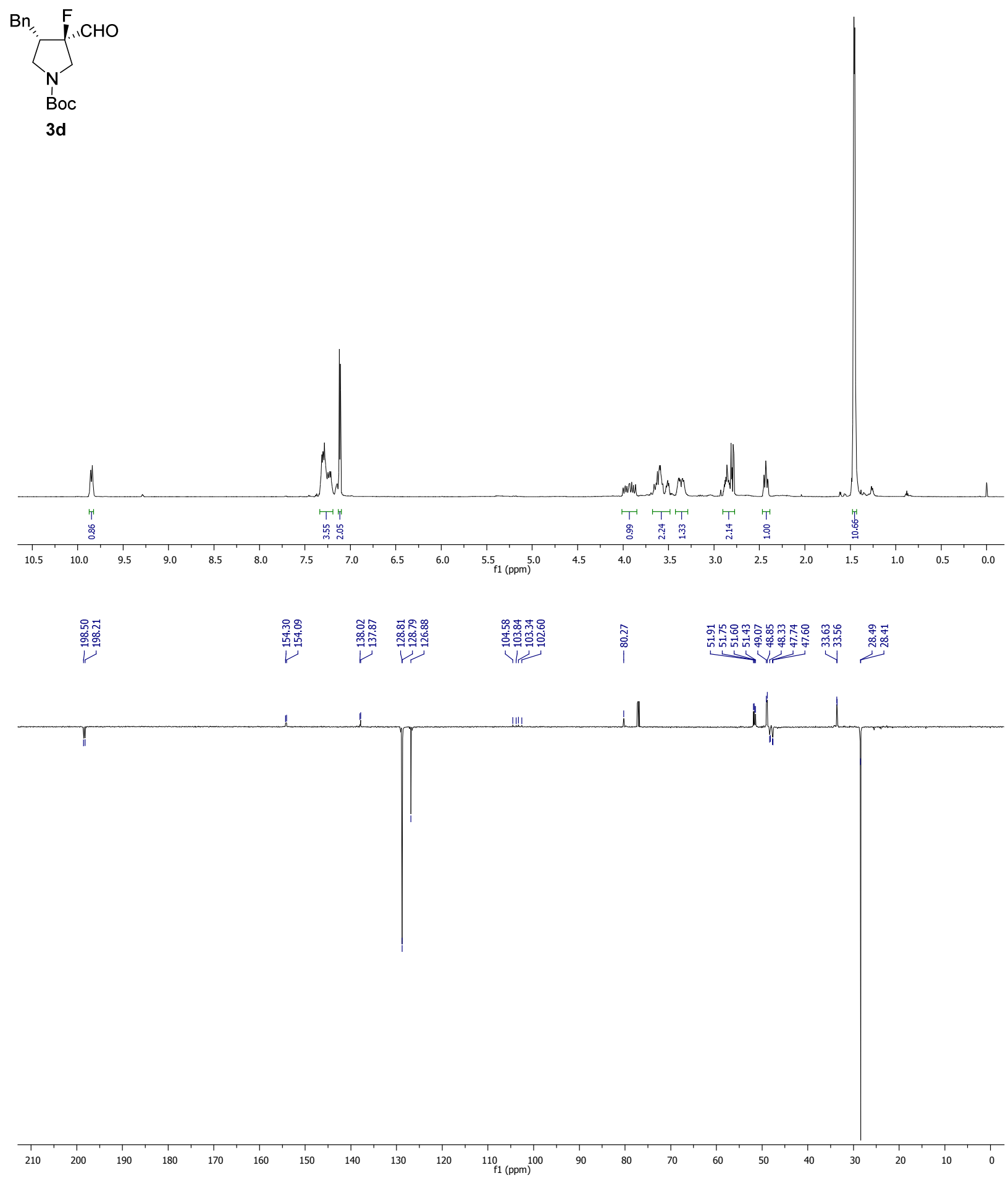


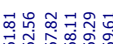

후ㅇㅝㅜ 운

V

II

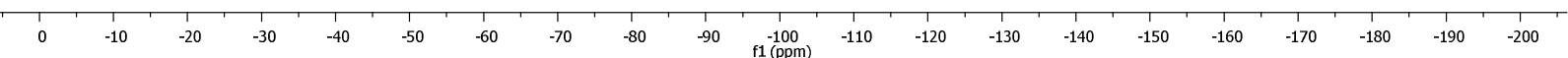




\section{tert-Butyl (3R,4S)-3-fluoro-3-(hydroxymethyl)-4-(pyridin-2-yl)pyrrolidine-1-carboxylate (11e)}

The NMR data was acquired at 600,151 or $471 \mathrm{MHz}$ for ${ }^{1} \mathrm{H},{ }^{13} \mathrm{C}$ or ${ }^{19} \mathrm{~F}$ NMR respectively in $\mathrm{CDCl}_{3}$.

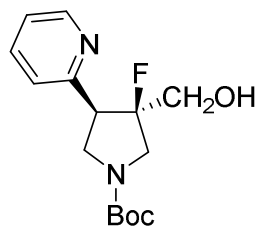

$11 \mathrm{e}$
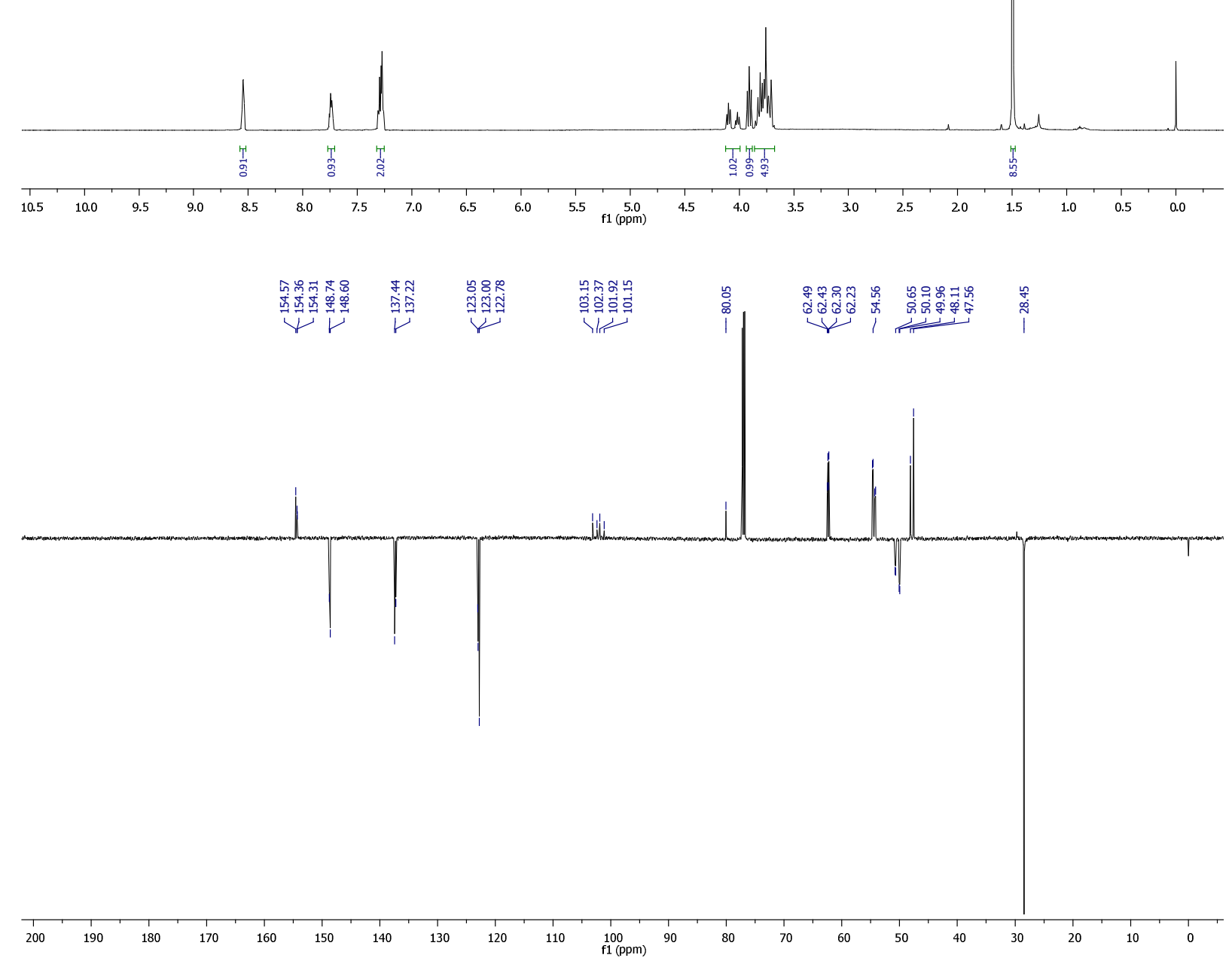


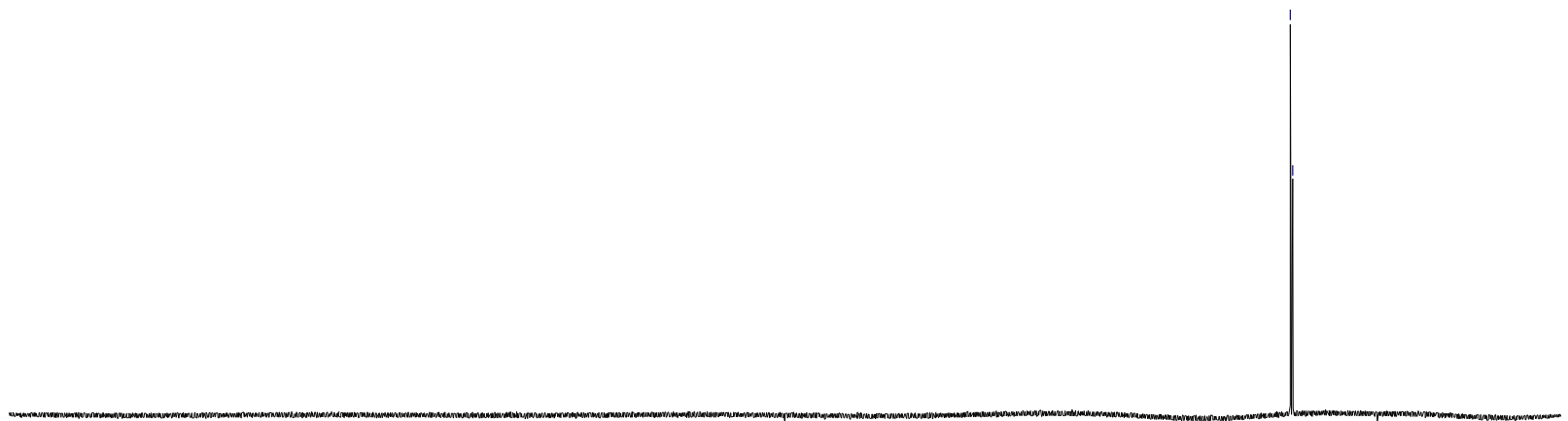

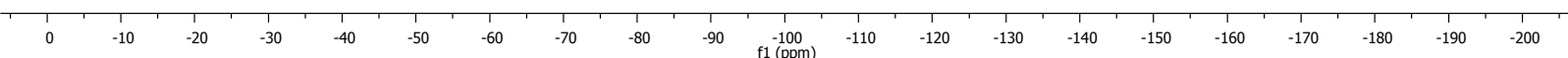


tert-Butyl (3S,4S)-3-fluoro-3-(hydroxymethyl)-4-(pyridin-2-yl)pyrrolidine-1-carboxylate (13e)

The NMR data was acquired at 600,151 or $471 \mathrm{MHz}$ for ${ }^{1} \mathrm{H},{ }^{13} \mathrm{C}$ or ${ }^{19} \mathrm{~F}$ NMR respectively in $\mathrm{CDCl}_{3}$.

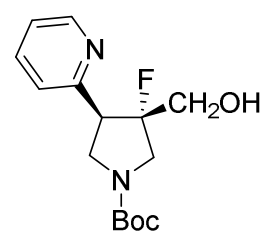

$13 e$
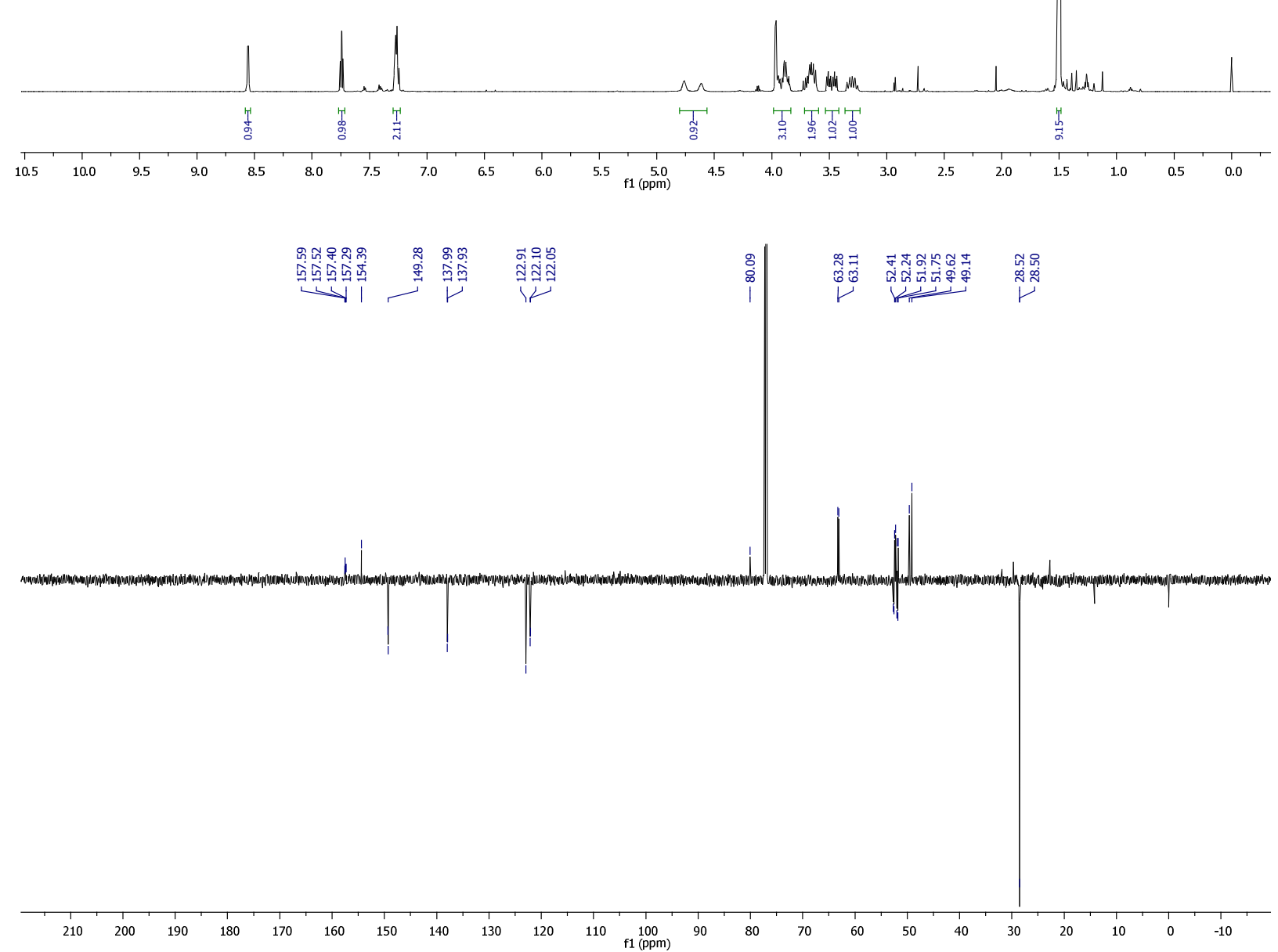


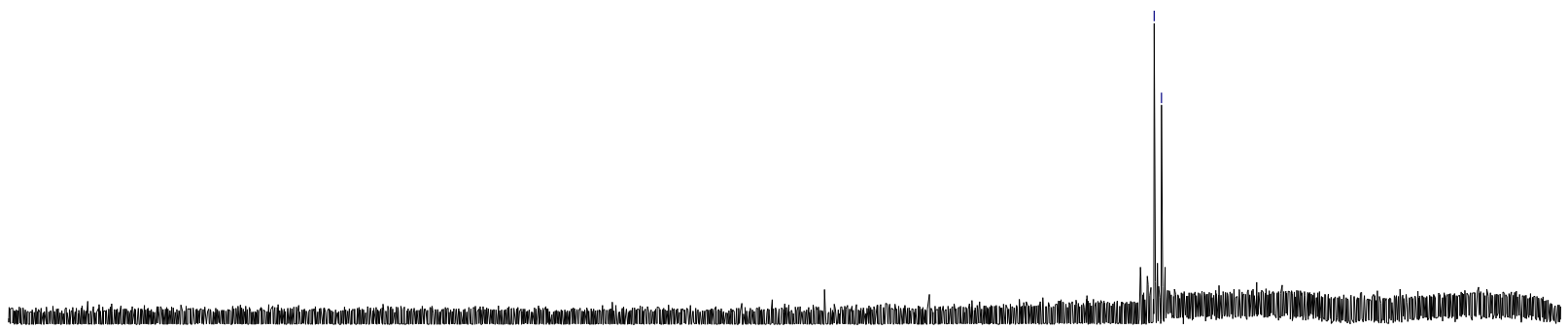

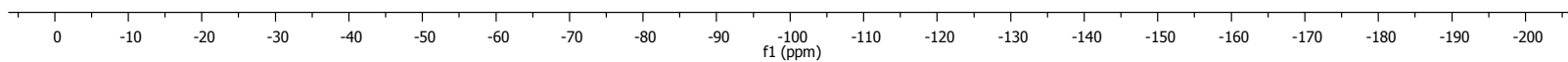




\section{tert-Butyl (3S,4S)-3-fluoro-3-formyl-4-(pyridin-3-yl)pyrrolidine-1-carboxylate (11f)}

The NMR data was acquired at 600,151 or $471 \mathrm{MHz}$ for ${ }^{1} \mathrm{H},{ }^{13} \mathrm{C}$ or ${ }^{19} \mathrm{~F}$ NMR respectively in $\mathrm{CDCl}_{3}$.
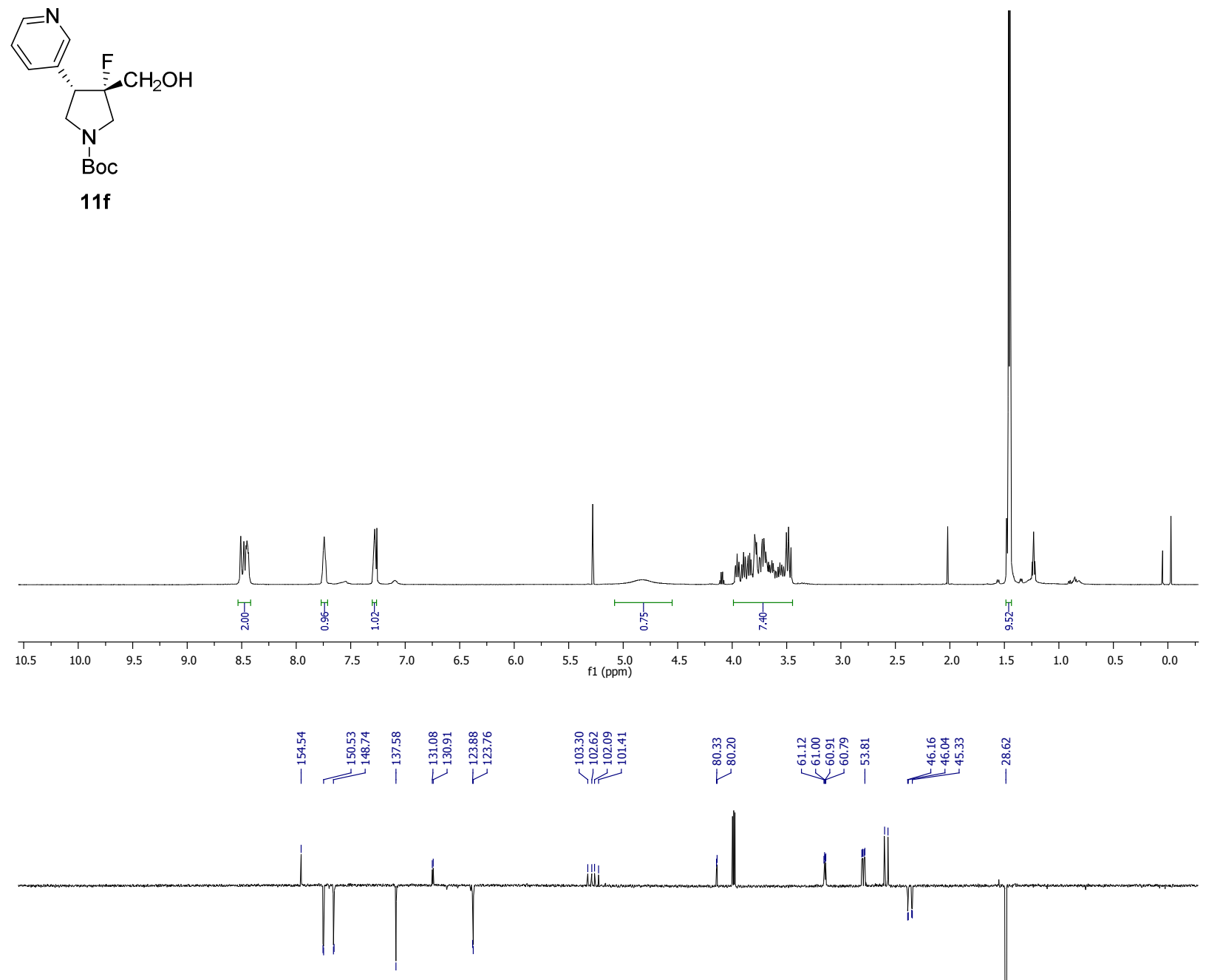

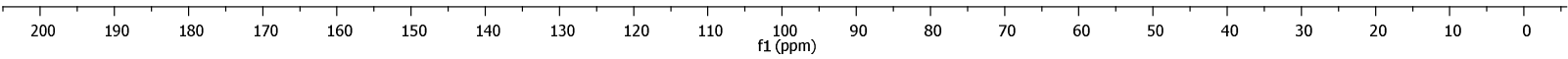




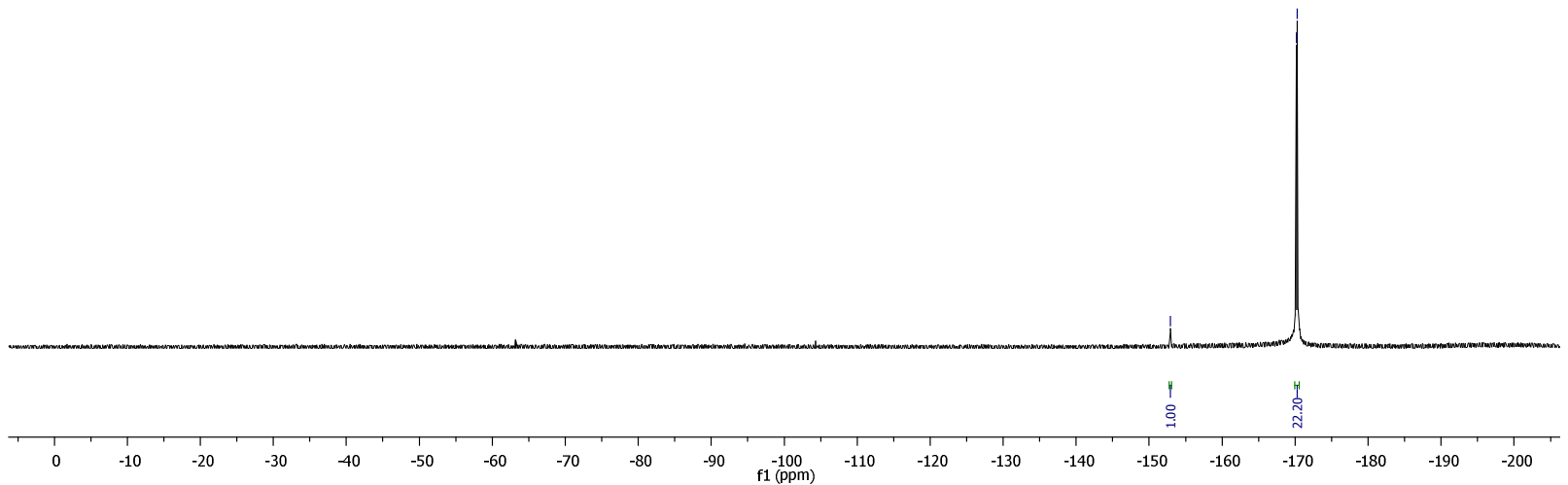


tert-Butyl (3R,4S)-3-fluoro-3-(hydroxymethyl)-4-(pyridin-3-yl)pyrrolidine-1-carboxylate (13f)

The NMR data was acquired at 600,151 or $471 \mathrm{MHz}$ for ${ }^{1} \mathrm{H},{ }^{13} \mathrm{C}$ or ${ }^{19} \mathrm{~F}$ NMR respectively in $\mathrm{CDCl}_{3}$.

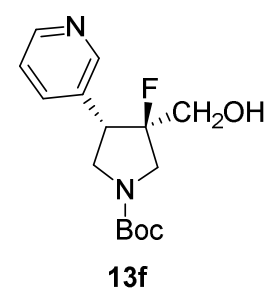

$13 f$
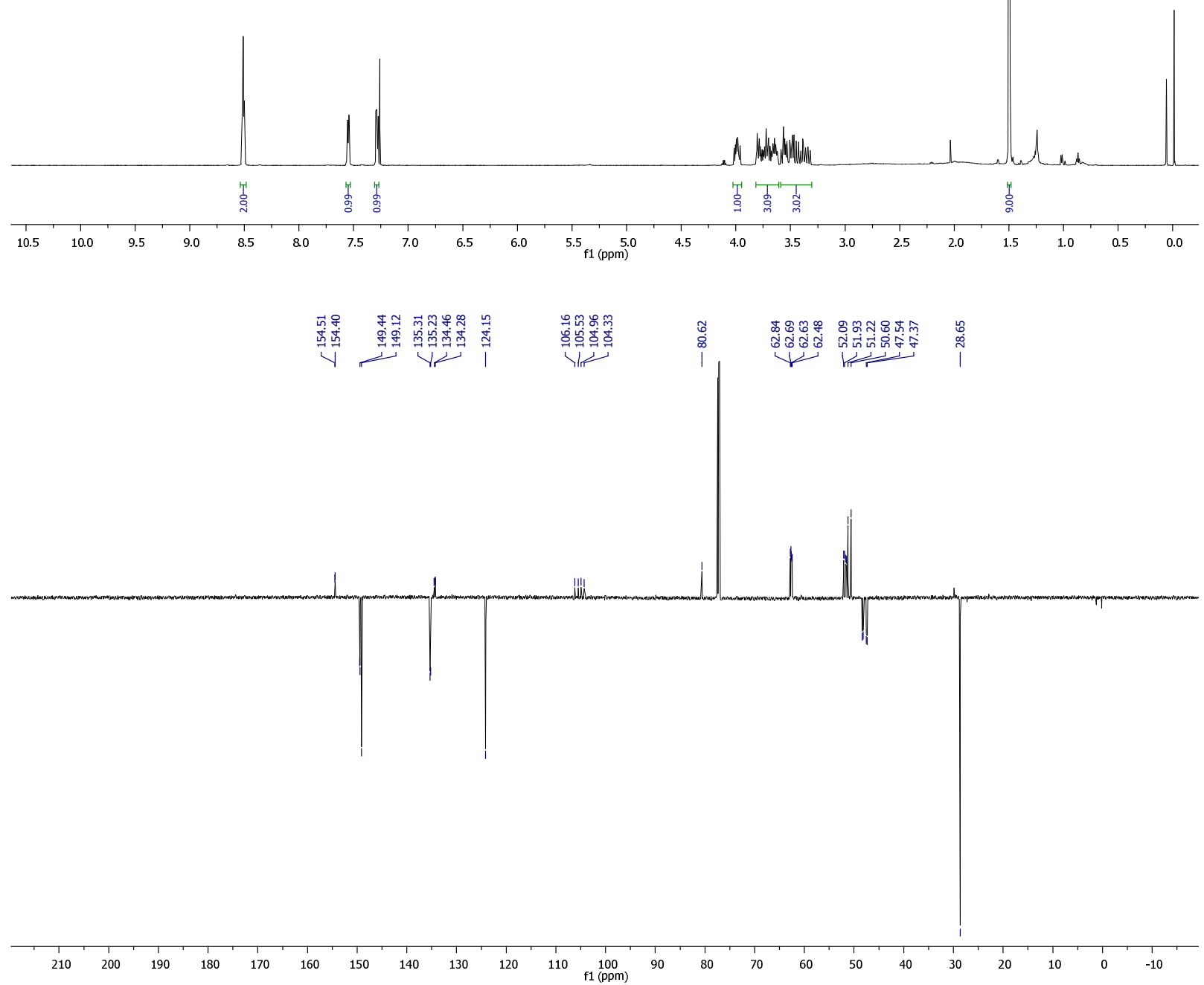


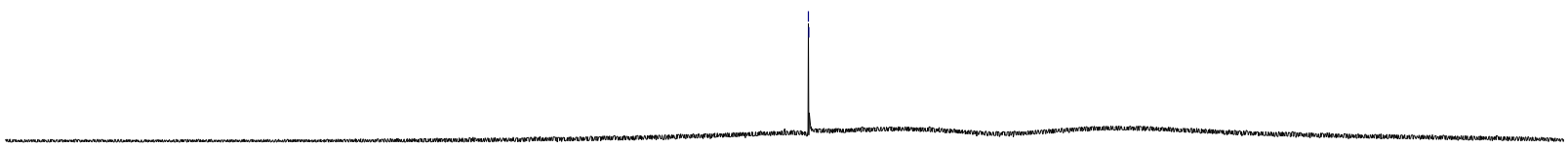

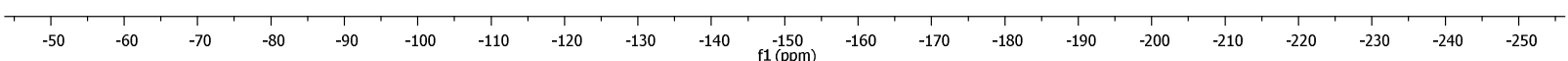




\section{tert-Butyl (3R,4R)-3-fluoro-3-formyl-4-(thiophen-2-yl)pyrrolidine-1-carboxylate (2g)}

The NMR data was acquired at 600,151 or $471 \mathrm{MHz}$ for ${ }^{1} \mathrm{H},{ }^{13} \mathrm{C}$ or ${ }^{19} \mathrm{~F}$ NMR respectively in $\mathrm{CDCl}_{3}$.

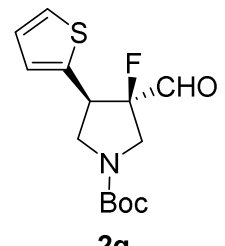

$2 \mathrm{~g}$
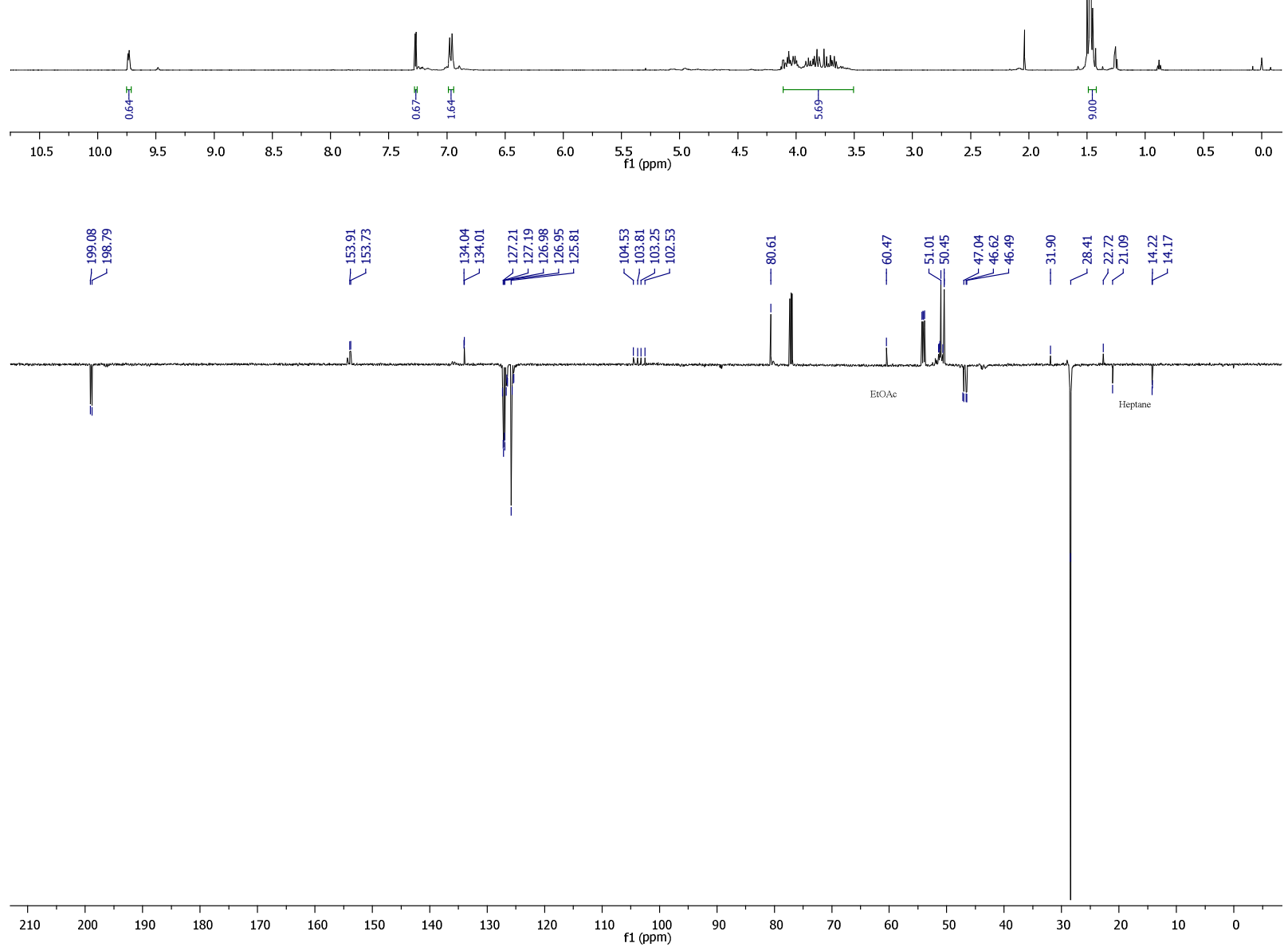
tert-Butyl (3R,4R)-3-fluoro-3-(hydroxymethyl)-4-(thiophen-2-yl)pyrrolidine-1-carboxylate (11g)

The NMR data was acquired at 600,151 or $471 \mathrm{MHz}$ for ${ }^{1} \mathrm{H},{ }^{13} \mathrm{C}$ or ${ }^{19} \mathrm{~F}$ NMR respectively in $\mathrm{CDCl}_{3}$.
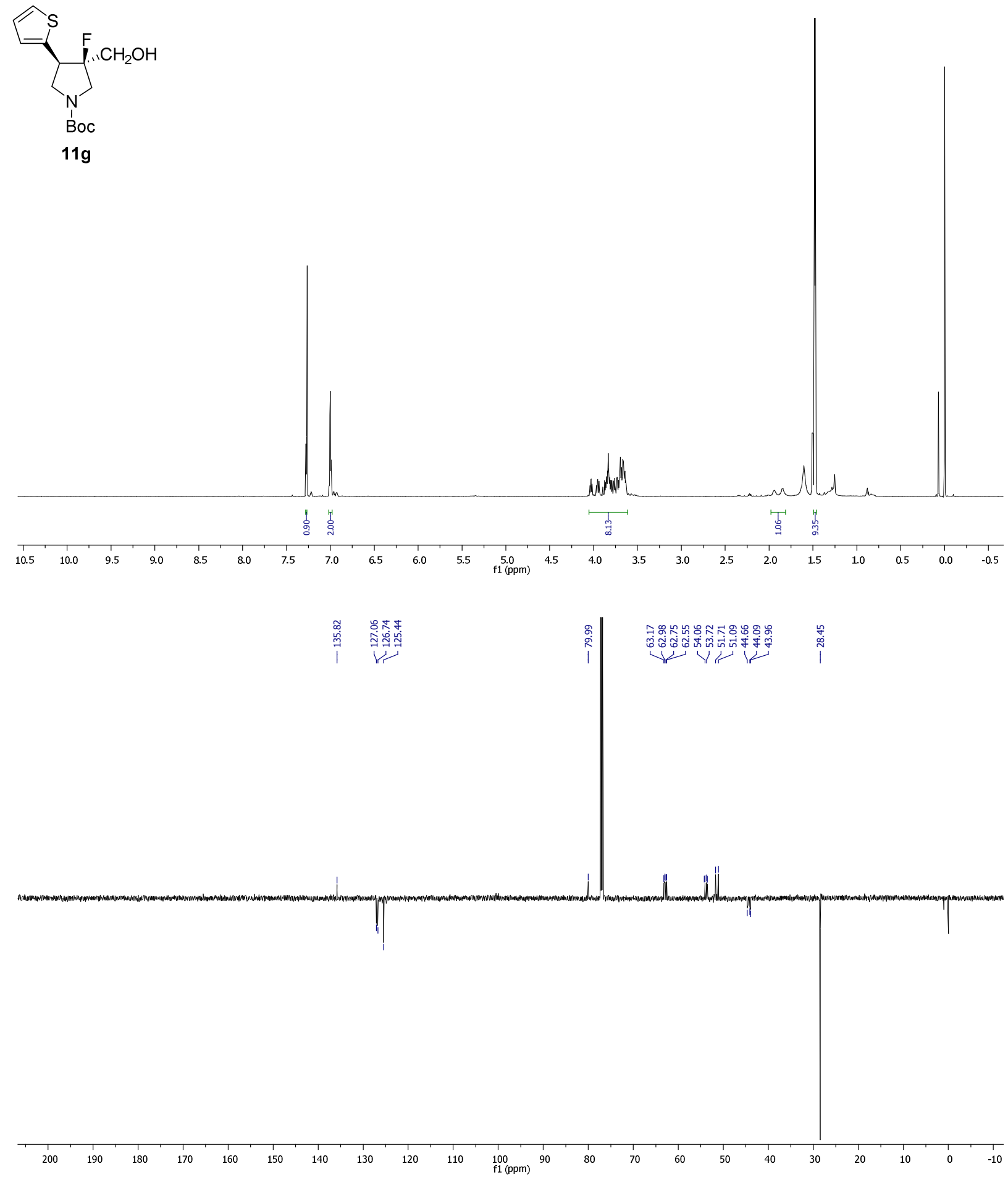
离

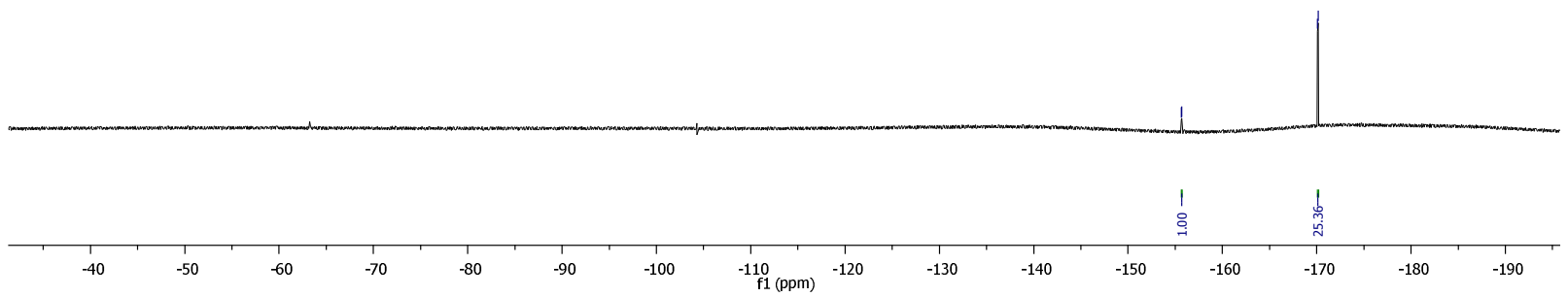




\section{tert-Butyl (3S,4R)-3-fluoro-3-formyl-4-(thiophen-2-yl)pyrrolidine-1-carboxylate (3g)}

The NMR data was acquired at 600,151 or $471 \mathrm{MHz}$ for ${ }^{1} \mathrm{H},{ }^{13} \mathrm{C}$ or ${ }^{19} \mathrm{~F}$ NMR respectively in $\mathrm{CDCl}_{3}$.
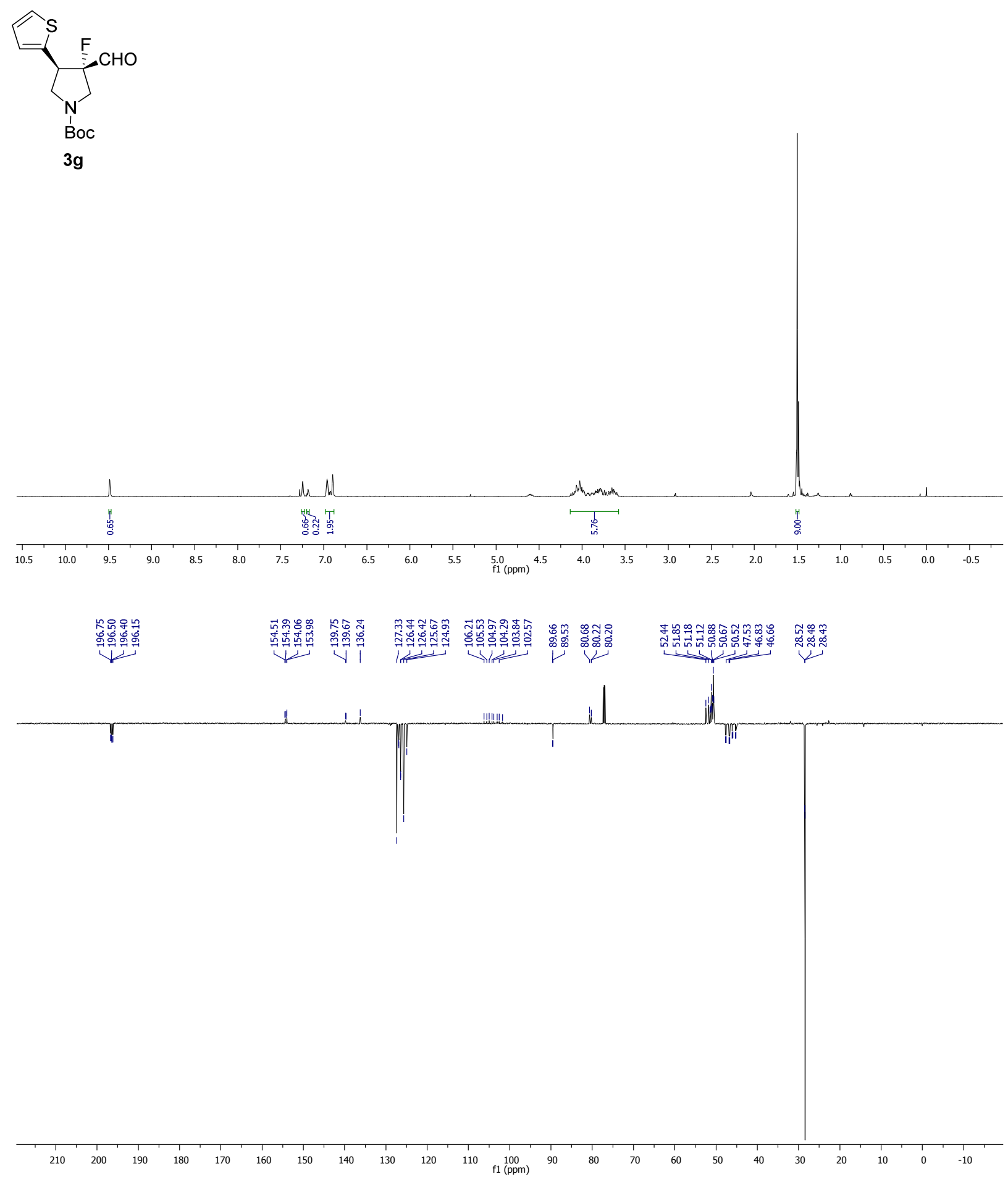
tert-Butyl (3S,4R)-3-fluoro-3-(hydroxymethyl)-4-(thiophen-2-yl)pyrrolidine-1-carboxylate (13g)

The NMR data was acquired at 600,151 or $471 \mathrm{MHz}$ for ${ }^{1} \mathrm{H},{ }^{13} \mathrm{C}$ or ${ }^{19} \mathrm{~F}$ NMR respectively in $\mathrm{CDCl}_{3}$.

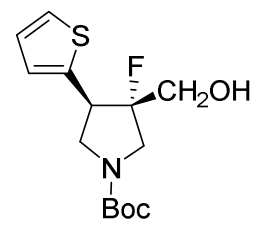

$13 g$
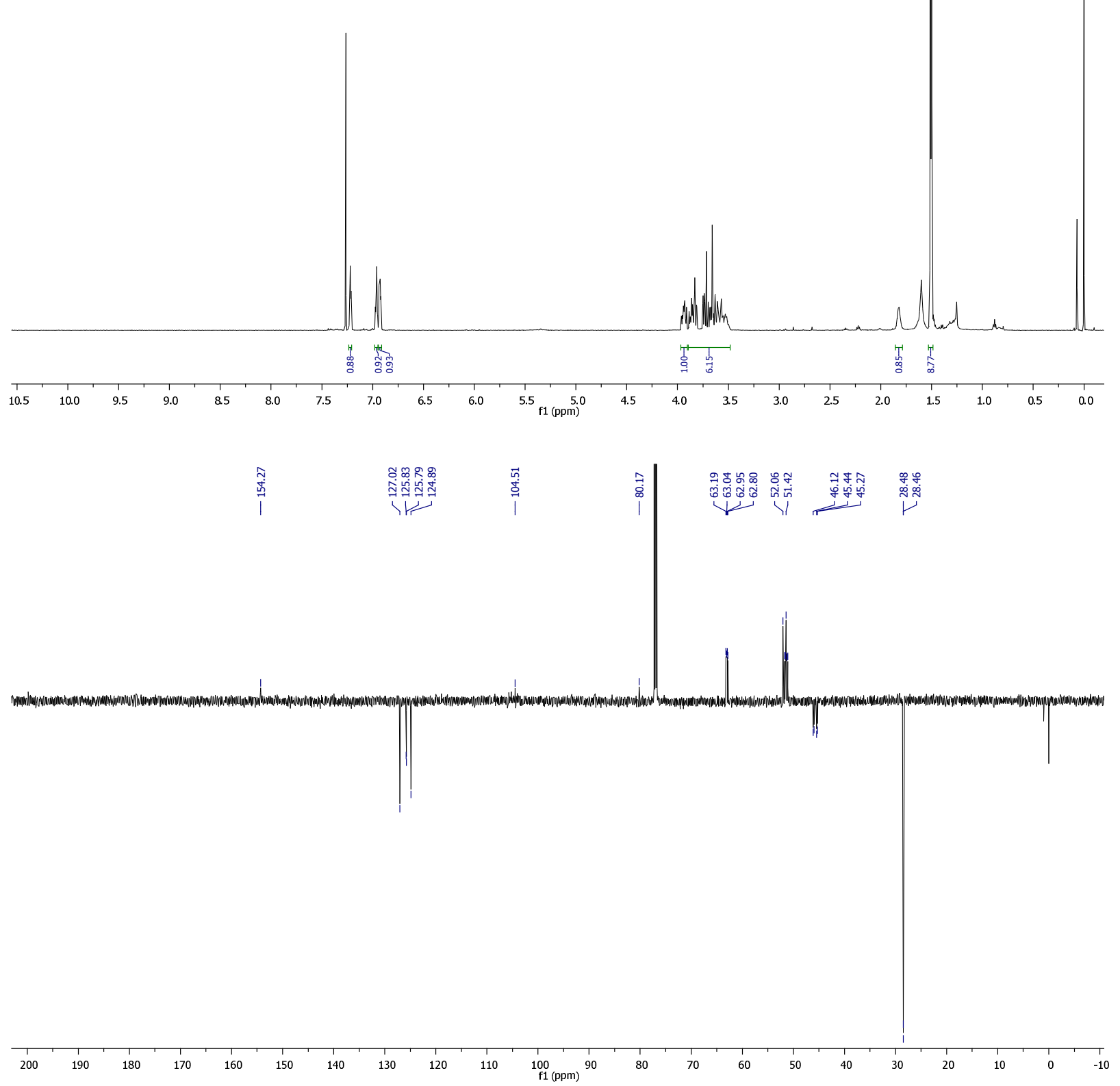


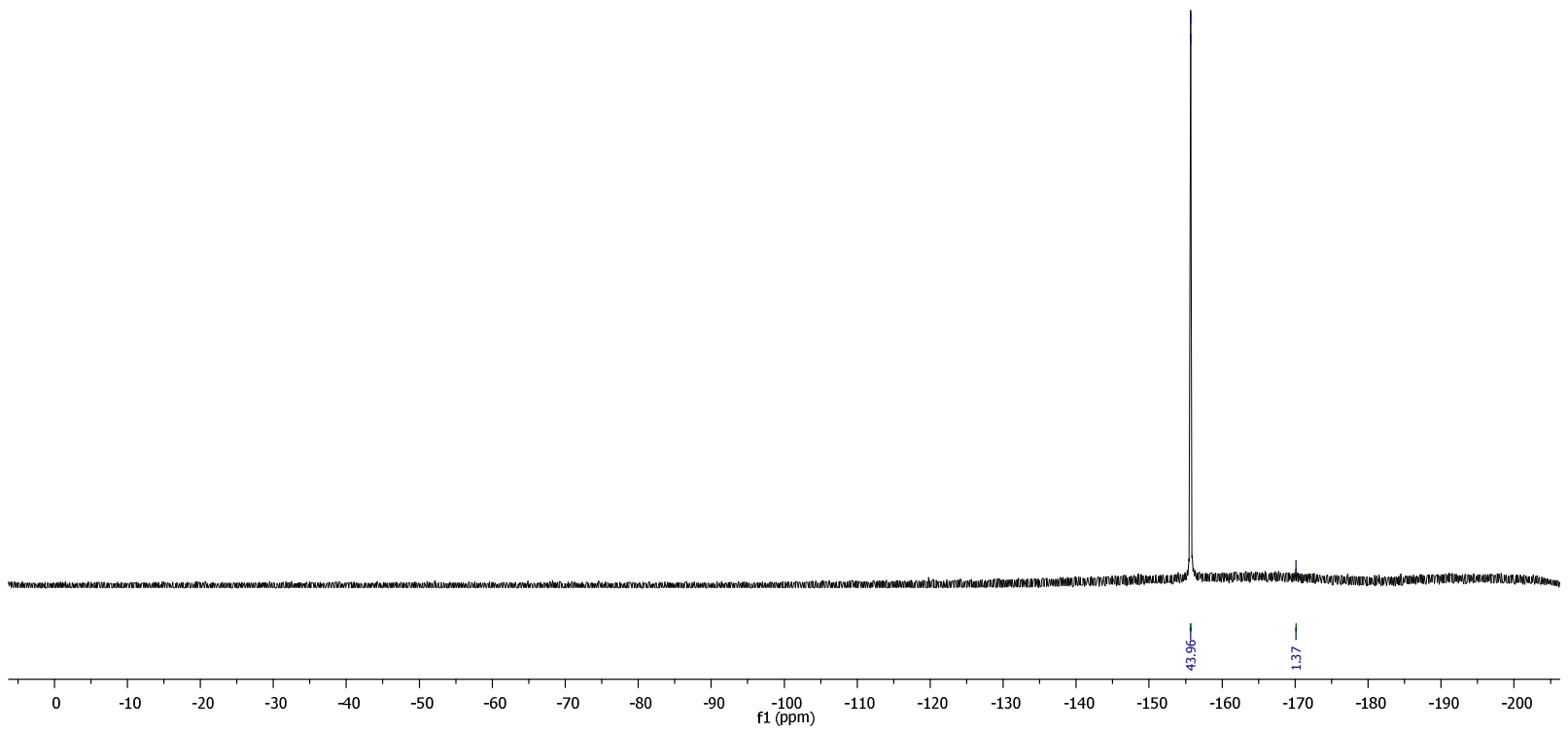




\section{Reference List}

1. Perlikowska, R.; Piekielna, J.; Mazur, M.; Koralewski, R.; Olczak, J.; do Rego, J. C.; Fichna, J.; Modranka, J.; Janecki, T.; Janecka, A. Bioorg. Med. Chem. 2014, 22, 4803.

2. Lorthiois, E.; Breitenstein, W.; Cumin, F.; Ehrhardt, C.; Francotte, E.; Jacoby, E.; Ostermann, N.; Sellner, H.; Kosaka, T.; Webb, R. L.; Rigel, D. F.; Hassiepen, U.; Richert, P.; Wagner, T.; Maibaum, J. J. Med. Chem. 2013, 56, 2207.

3. Meyer, S. D.; Schreiber, S. L. J. Org. Chem. 1994, 59, 7549. 